\author{
UNIVERSIDADE DE SÃO PAULO \\ ESCOLA DE ENFERMAGEM
}

RAQUEL APARECIDA DE OLIVEIRA

A UNIVERSIDADE COMO ESPAÇO PROMOTOR DE QUALIDADE DE VIDA: Vivências e expressões dos alunos de enfermagem.

São Paulo

2005 
Raquel Aparecida de Oliveira

\title{
A UNIVERSIDADE COMO ESPAÇO PROMOTOR DE
}

QUALIDADE DE VIDA: Vivências e expressões dos alunos de enfermagem.

\begin{abstract}
Tese apresentada ao Programa Interunidades de Doutoramento dos "campi" de São Paulo e Ribeirão Preto da Universidade de São Paulo, para obtenção do título de Doutor em Enfermagem.
\end{abstract}

Orientadora: Prof.a Dra. Maria Helena Trench Ciampone

São Paulo 


\section{Catalogação na publicação (CIP)}

\section{Biblioteca "Wanda de Aguiar Horta" da EEUSP}

Oliveira, Raquel Aparecida de

A universidade como espaço promotor de qualidade de vida: vivências e expressões dos alunos de enfermagem. / Raquel Aparecida de Oliveira. - São Paulo: R.A. de Oliveira, 2005.

$233 \mathrm{p}$.

Tese (Doutorado) - Escola de Enfermagem da Universidade de São Paulo. Programa Interunidades de Doutoramento em Enfermagem.

Orientadora: $\operatorname{Prof}^{a} \operatorname{Dr}^{a}$ Maria Helena Trench Ciampone

1. Enfermagem (educação) 2. Qualidade de vida no trabalho 3. Estudantes universitários 4. Estudantes (Enfermagem). I. Título. 


\section{Dedicatória}

À memória de meu pai, o dos inesquecíveis olhos azuis, que me quis bem, me compreendeu, me cuidou, e sobretudo me mostrou a essência do cuidar.

Ao alunos, pacientes, enfermeiros e professores que no "concerto" desta vida permitem-me a aprender: a aprender, fazer, sentir e ser.

Ao Cláudio, companheiro amoroso, pela dedicação e compreensão sempre presente. 


\section{Agradecimentos}

Agradecer é um momento de celebrar a presença do outro no nosso viver.

Á Prof.a Dra. Maria Helena Trench Ciampone, orientadora, Agradeço pelo estímulo constante, pela confiança e pela leveza e sabedoria com que me conduziu neste caminho.

Á Prof.a Dra. Wanda, pelo acolhimento sempre presente e pelas suas contribuições neste estudo.

Á Prof.a Dra. Maria Júlia Kovács, pela coerência das sugestões no exame de qualificação.

Aos meus colaboradores, razão deste estudo.

Ás docentes do Departamento de Orientação Profissional da EEUSP, pelo incentivo e carinho com que sempre me receberam.

Aos colégas do Núcleo de Estudos e Pesquisa dos Aspectos

Psicossociais do Ensino e da Assistência em Saúde (NEPAPEAS), pelo compartilhar do conhecimento e crescimento.

Á Dra. Luciane Garcia Silveira, que cuidou-me com carinho e firmeza, permitindo a retomada dos meus projetos de vida.

Á Maria Amália, á Tyi e aos colegas de formação em coordenação de grupos, pelo acolhimento e aprendizado vivido.

Ao Sr. Aurélio Tomazella, pela disponibilidade e atenciosa revisão do texto deste trabalho;

Aos amigos e familiares que, souberam compreender a minha ausência, mas que estiveram sempre presentes em meu coração. “... que maravilha viver, se todos fossem no mundo, iguais à vocês.” 
OLIVEIRA RA. A UNIVERSIDADE COMO ESPAÇO PROMOTOR DE

QUALIDADE DE VIDA: Vivências e expressões dos alunos de enfermagem

[Tese] São Paulo (SP): Escola de Enfermagem das USP, 2005.

\section{RESUMO}

Considerando o processo de formação vivenciado, particularmente, pelos alunos de graduação em enfermagem da PUC/SP e suas relações com a qualidade de vida, esta pesquisa teve como objetivos: identificar as percepções que o aluno de graduação em enfermagem tem em relação a sua qualidade de vida atual e a futura qualidade de vida no trabalho; compreender e analisar as principais demandas por eles evidenciadas no resgate das situações vividas e as estratégias de enfrentamento utilizadas que impactam na melhoria da sua qualidade de vida. A pesquisa foi qualitativa, e os dados forma obtidos por meio de entrevistas individuais, na primeira fase. A análise dos temas resgatados dos discursos na primeira fase, nortearam os temas disparadores dos cinco encontros de grupo focal na segunda fase. Nesse sentido trata-se de uma modalidade de pesquisaação. Os dados gerados nos encontros grupais foram analisados segundo a modalidade da análise temática, estruturada nas categorias: qualidade de vida; qualidade de vida no trabalho; qualidade de vida dos trabalhadores de enfermagem e qualidade de vida de estudantes universitários. Após análise foi realizada uma adaptação do Modelo Ecológico de QVE proposto por Benjamin (1994) considerado capaz de apreender a qualidade de vida dos alunos de enfermagem. Os resultados evidenciaram que a Universidade é um espaço que propicia vivências de promotoras e não promotoras de qualidade de vida dos alunos. Ficou evidente a necessidade de implantação de encontros sistematizados, no curriculum, nos quais alunos e professores tenham a oportunidade de discutir a construção individual e coletiva de estratégias de enfrentamento das situações geradoras de desgaste favorecendo o fortalecimento da qualidade de vida dos mesmos.

Descritores: Enfermagem (educação); Qualidade de vida no trabalho; Estudantes universitários; Estudantes (Enfermagem). 


\section{OLIVEIRA RA. THE UNIVERSITY AS A PLACE THAT PROMOTES QUALITY OF LIFE - Perceptions and experiences of nursing students $-\{$ Thesis $\}$ - São Paulo (SP) : Nursing School from USP,2005.}

\section{SUMMARY}

Considering the perceptions about the development process experienced specifically by the nursing students from PUC/SP and their relation with quality of life, this research has had the following objectives: identify the perceptions the nursing students have in relation to their present quality of life and their future quality of life at work; understand and analyse the main requirements evidenced by them in rescuing the situations they have lived and the directions and suggested confrontation strategies that may impact on improving their quality of life. The research was the qualitative mode and, in the first stage, the data were obtained through individual interviews. The analysis of the topics taken from this first stage guided the starting themes of the five meetings of the focus group in the second stage. Because of this it is a research - action type. The data obtained in the group meetings were analysed according to the thematic analyses mode based on the following categories: quality of life at work, quality of life of nursing workers and quality of life of university students. After the analysis was done, it was adjusted to the "Students Ecological Model of Quality of Life" proposed by Benjamin (1994), considered able to grasp the quality of life of nursing students. The results showed that the University is a place that provides perceptions that promote or not students quality of life. It was very clear the need to implement systematic meetings in the curriculum so that both students and teachers may have the opportunity to discuss the individual and collective development of strategies to face the stressing situation they experience so that they may strengthen their quality of life.

KEY WORDS : Work Quality of Life; Nursing Students; Nursing (Education); University students. 


\section{Sumário}

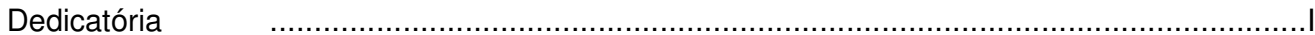

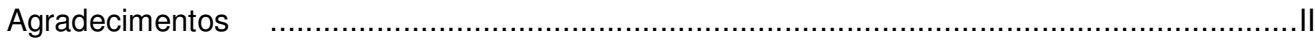

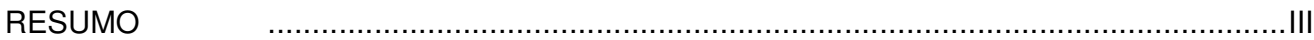

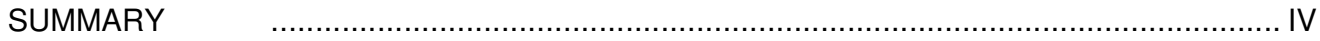

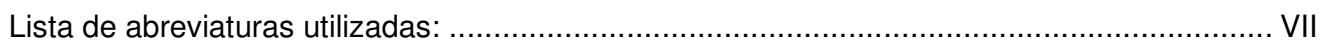

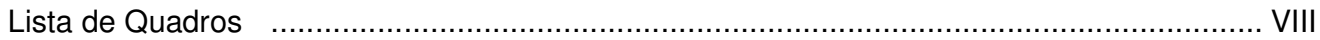

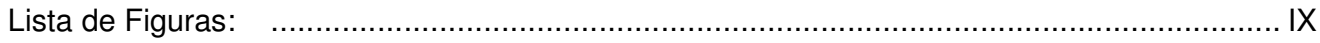

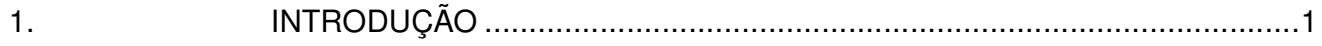

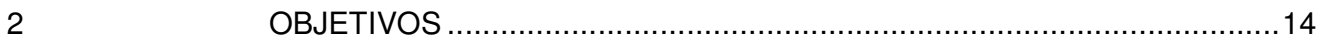

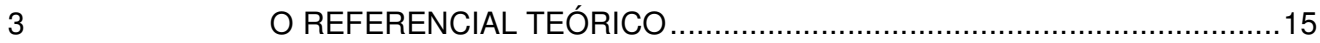

3.1 O Contexto Histórico do Ensino da Enfermagem no Brasil ........................16

3.2 Qualidade de vida. Os diferentes conceitos ...........................................23

3.2.1 Qualidade de vida no trabalho e qualidade de vida dos trabalhadores de

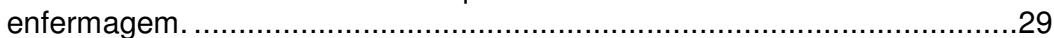

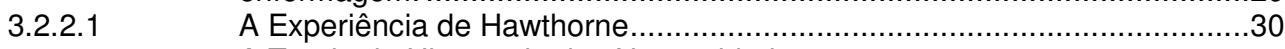

3.2.2.2 A Teoria da Hierarquia das Necessidades ...........................................33

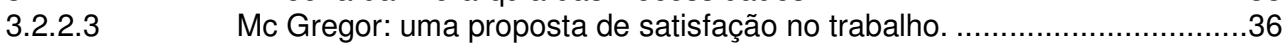

3.2.2.4 A Teoria dos Dois Fatores ........................................................

3.2.2.5 A Teoria das Necessidades Aprendidas .............................................41

3.3 Conceitos de Qualidade de Vida no Trabalho ......................................43

A Visão Contemporânea da QVT ....................................................49

3.5 A Qualidade de Vida no Trabalho da Enfermagem................................51

3.6 Qualidade de Vida em estudantes universitários ..................................59

3.6.1 Qualidade de Vida em estudantes de Enfermagem.................................69

4

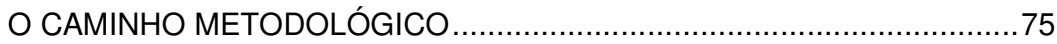

4.1

4.2

4.3

4.3.1

4.3.1.1

4.3.1.2

4.3.2

4.3.2.1

4.3.2.2

4.4

4.4 .1

4.4 .2

4.4.2.1

O Cenário do estudo.........................................................................

O Currículo do Curso de Enfermagem da PUC/SP ................................. 80

Os procedimentos para a coleta de dados .......................................... 86

O Primeiro Momento da Coleta de Dados ............................................ 87

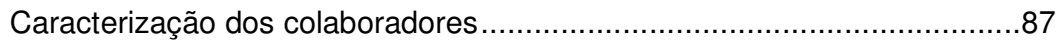

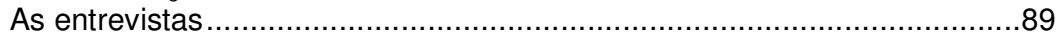

O Segundo Momento da Coleta de Dados ..........................................91

Caracterização dos Colaboradores ..................................................91

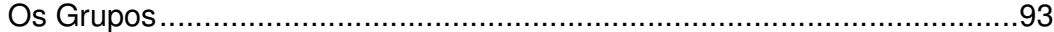

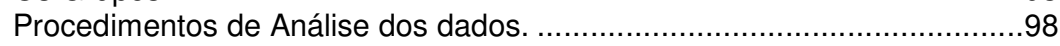

Apresentação e análise das Entrevistas............................................100

Apresentação e análise dos Grupos ...............................................109

O Primeiro Encontro ................................................................ 110 


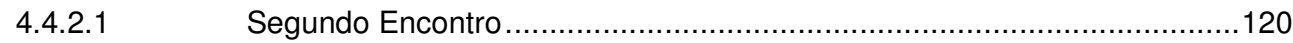

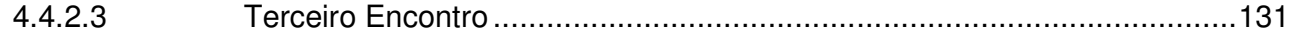

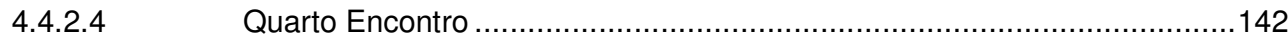

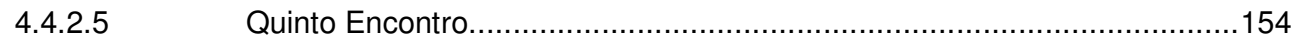

5

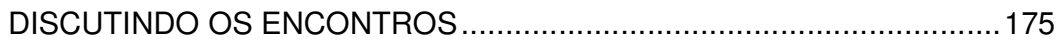

6

A UNIVERSIDADE COMO ESPAÇO DE VIVÊNCIA DA QVEENF 200

7

REFERÊNCIAS BIBLIOGRÁFICAS ............................................209

ANEXO 1

218

ANEXO 2

219

ANEXO 3

220

ANEXO 4

221

ANEXO 5

223

ANEXO 6 


\title{
Lista de abreviaturas utilizadas:
}

\author{
GF - Grupo Focal \\ QV - Qualidade de Vida \\ QVT - Qualidade de Vida do Trabalhador \\ QVE - Qualidade de Vida dos Estudantes.
}

QVEEnf. - Qualidade de Vida dos Estudantes de Enfermagem. 


\section{Lista de Quadros}

Quadro 1: $\quad$ Síntese os conceitos de Maslow descritos Bertoni (1994) e os utilizados pela Administração na década

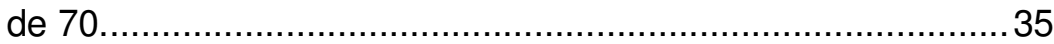

Quadro 2: $\quad$ Definições Evolutivas da QVT ................................................. 48

Quadro 3: $\quad$ Qualidade de vida de estudantes de enfermagem revisão bibliográfica nos periódicos do Brasil relacionados com QVE.Enf., 1999 - 2005........................... 70

Quadro 4: Perfil dos alunos matriculados no Curso de Enfermagem no período de 1999 à $2005 . . . \ldots \ldots \ldots \ldots \ldots \ldots \ldots \ldots . . . . . . . . . . . . . .79$

Quadro 5: $\quad$ Caracterização dos colaboradores da primeira etapa da coleta de dados. 88

Quadro 6: Caracterização dos colaboradores da segunda etapa da coleta de dados. ...................................................92 


\section{Lista de Figuras:}

Figura 1: Modelo Ecológico de QVE proposto por Benjamin (1994) 64

Figura 2: $\quad$ Modelo Ecológico de QVEEnf. adaptado do proposto por Benjamin (1994). 180

Figura 3: Estratégias para melhoria da QVEst de Enf., segundo o Modelo Ecológico de QVEst. Enfermagem adaptado do proposto por Benjamin (1994) 


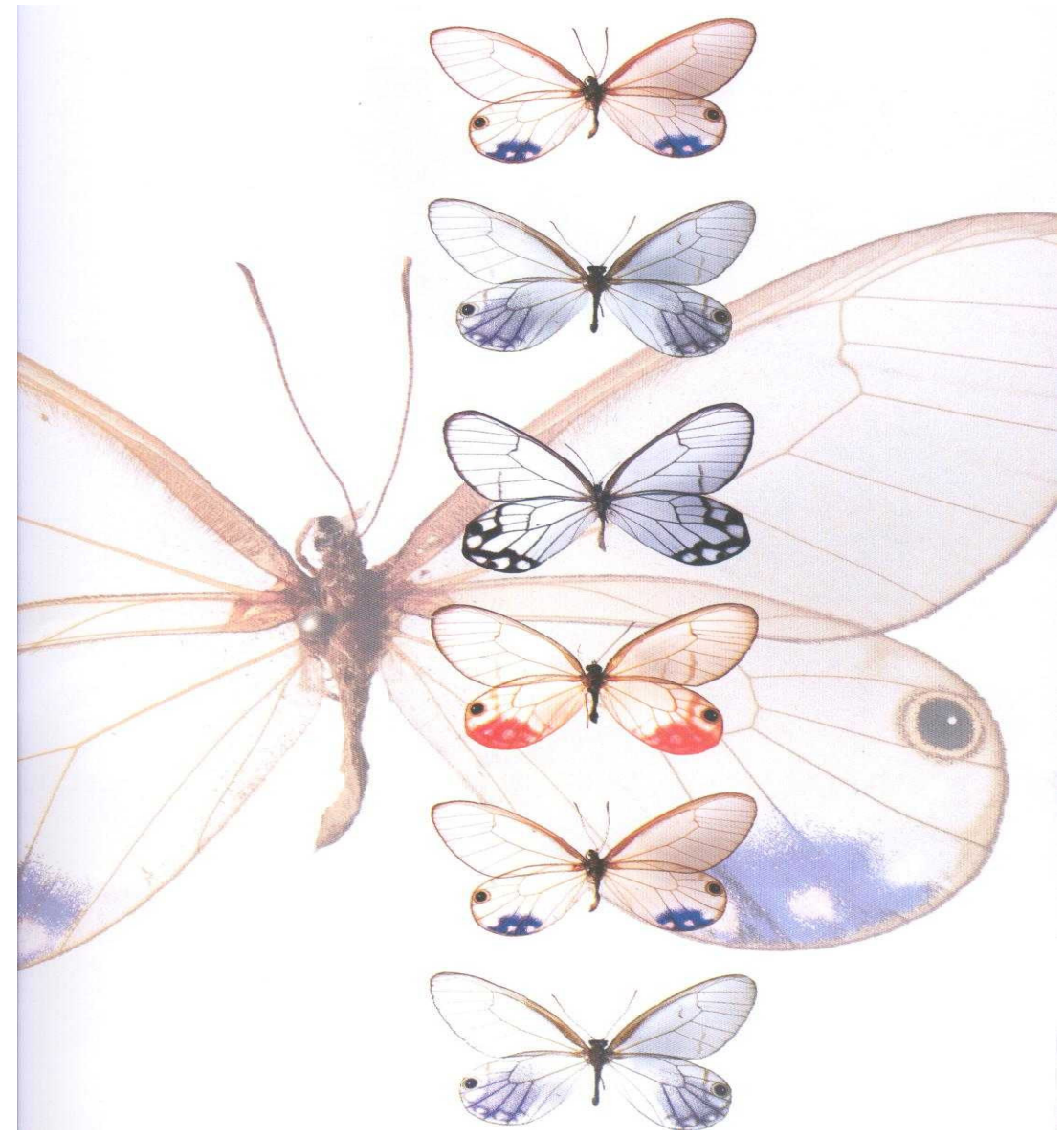

"Procuro despir-me do que aprendi,

Procuro esquecer-me do modo de lembrar que me ensinaram,

E raspar a tinta com que me pintaram os sentidos, Desencaixotar as minhas emoções verdadeiras, Desembrulhar-me e ser eu..."

(Fernando Pessoa, 1985) 


\section{INTRODUÇÃO}

Refletindo sobre o início de uma nova etapa, percebo que em minha trajetória de vida, extraordinariamente, persisti na busca de um crescimento pessoal e cheguei até aqui.

Com os pais que tive, eu deveria ter sido a boa esposa, dona de casa, quando muito, professora primária. Na minha família não era comum estudar além do primeiro grau (antigo ginásio), muito menos as mulheres. Em vez disso, na minha adolescência, rompi com esta expectativa de meus pais, fui trabalhar e preparar-me para seguir adiante nos estudos.

Sempre estudei em escola pública sendo que, no segundo grau, trabalhava e estudava à noite. Preparei-me com muito empenho e assim, graduei-me em Enfermagem, pela Universidade de Campinas (UNICAMP). Posteriormente especializei-me em Saúde Pública, área em que atuei por oito anos.

De volta a minha cidade de origem, São Roque (SP), trabalhei durante quatro anos em Unidade Básica de Saúde e também como coordenadora e docente no Curso de formação de Auxiliares de Enfermagem no Programa de Classes Descentralizadas.

Posteriormente, trabalhei na Prefeitura de Alumínio, onde me dediquei em grande parte à saúde das mulheres e à prevenção do 
câncer, em especial do câncer de mama, tema que desenvolvi em minha dissertação de Mestrado em Educação pela Universidade de Sorocaba.

Nessa ocasião também trabalhava como docente no Departamento de Enfermagem da Pontifícia Universidade de São PauloCampus Sorocaba e dadas às exigências da docência, após a conclusão do Mestrado, e as demandas do meu trabalho na Saúde Pública, optei, então, por assumir a docência em regime de dedicação exclusiva.

Seguindo o meu desejo de continuar a carreira acadêmica e a necessidade de corresponder às demandas do processo ensinoaprendizagem e compreender os alunos em suas necessidades durante a formação, empenhei-me para o ingresso no doutorado.

Durante o processo de construção do projeto e amadurencimento quanto ao objeto de estudo, comecei a pensar na minha qualidade de vida. Até então eu tinha sempre atuado em dois empregos e havia sido uma aluna trabalhadora desde os meus quatorze anos. Nesse momento, tive consciência de que a possibilidade de fazer opções, se deveu à trajetória percorrida.

Neste momento da minha vida, o interesse deste estudo foi ao encontro das minhas reflexões, enquanto pessoa que investiu sua vida em uma qualificação profissional e que, por inúmeras vezes, negligenciou o seu próprio cuidado. 
Hoje, minha principal atividade é a docência; trabalho no processo de formação de futuros cuidadores e me questiono a quantas anda a qualidade de vida destes futuros cuidadores. Teriam eles consciência da necessidade do cuidado de si para que possam de fato cuidar de outros?

No exercício de ser mediadora do processo de aprendizado dos meus alunos, questionei: como facilitar esse processo para alguém que pouco conhecemos? Nesse lugar, nos professores, não poderia deixar de conhecer suas histórias, seus contextos de vida, saber dos seus sentimentos, ansiedades, angústias, sofrimentos, medos, alegrias, prazeres, fracassos, vitórias.

Então, passei a indagar qual tem sido o papel da Universidade em relação à promoção da qualidade de vida desses futuros cuidadores.

Diante do contexto em que a qualidade de vida perpassa a questão da formação do profissional, repensar a relação do docente com o aluno no seu processo de formação, e com o futuro profissional de saúde, merece um espaço de atenção. Portanto, o educador, deve resgatar o seu papel como facilitador e propiciar o início de um processo que desperte no aluno o reconhecimento, a compreensão e intervenção voltada para os fatores determinantes da sua própria qualidade de vida enquanto aluno e futuro profissional. 
Em resposta a este desafio, valho-me de Antunes, C (2001), que ancora as quatro aprendizagens essenciais, como norteadoras da prática do educador. Essas são descritas da seguinte forma:

- Aprender a conhecer. Consiste em adquirir as competências para a compreensão, incluíndo o domínio dos próprios instrumentos do conhecimento. Ou seja, quem aprende a conhecer aprende a aprender, e essa aprendizagem é absolutamente essencial para as relações interpessoais, as capacidades profissionais e os fundamentos de uma vida digna.

- Aprender a fazer. Esta segunda aprendizagem enfatiza a questão da formação profissional e o preparo para o mundo do trabalho. Aprender a fazer significa despertar e estimular a criatividade para que se descubra o valor construtivo do trabalho, sua importância como forma de comunicação entre o homem e a sociedade, seus meios como ferramentas de cooperação e para que transforme o progresso do conhecimento em novos empreendimentos e em novos empregos.

- Aprender a viver juntos e com os outros. Esta aprendizagem diz respeito ao papel do professor transformar o espaço escolar em um centro de descoberta do outro e também um espaço que estimule 
projetos solidários e cooperativos, identificados por objetivos comuns. O autor entende que, os caminhos do autoconhecimento e da auto-estima são os mesmos da solidariedade e da compreensão.

- Aprender a ser: Trata-se da retomada da visão holística e integral do homem. Aprender a ser consiste em preparar o ser humano inteiramente-espírito e corpo, inteligência e sensibilidade, sentido estético e responsabilidade pessoal, ética e espiritualidade, de forma que o aluno elabore pensamentos autônomos e críticos e também formule os próprios juízos de valores, de modo a decidir, por si mesmo, como agir em diferentes circunstâncias da vida.

Ciampone, (1998) estudando as percepções de docentes sobre a relação professor-aluno na formação do profissional enfermeiro, mostra que os docentes assinalaram, que o sistema tradicional de ensino, com sua forma de avaliação característica, incide sobre o sistema de representações que o sujeito da aprendizagem tem de si mesmo, levando-o a perceber-se como desconhecedor, impotente e ignorante. Também relatam que o sistema tradicional não prepara o futuro profissional para interrogar a realidade, isto é, esse sistema tende a transformar o pensamento e a experiência em desconhecimento e, nesse sentido, vai desqualificando o estudante por desvincular do que pensa do que sente e de 
como age. Com isto, Ciampone (1998) conclui que a escola, de um modo geral, tende a reproduzir o fenômeno da alienação sujeito-profissional, reforçando mecanisnos de defesa, diante do medo e da exposição ao desconhecido e da avaliação que, majoritariamente, tem se baseado na assimilação ou não, de conteúdos informativos e menos no processo formativo.

Menzies (1970) cita em seu estudo, a necessidade de dirigirmos a atenção para além da natureza da tarefa de cuidar, presente na profissão de enfermagem, para os mecanismos utilizados no serviço de enfermagem para conviver com situações de ansiedade, como por exemplo, a manutenção da fragmentação do relacionamento enfermeiro-paciente, despersonalização, categorização e negação da importância do indivíduo que se explicitam indiretamente em afirmações como: "os pacientes são todos iguais"; "o leito no 18 vai para cirurgia"; distanciamento e negação de seus próprios sentimentos, tentativa de eliminar decisões pelo ritual de desempenho de tarefas, no chamado de assistência funcional que acaba distanciando os cuidadores do paciente/cliente como um todo, centrado na relação, na técnica ou procedimento a ser desenvolvido; forte senso de responsabilidade, idealização e subestimação das possibilidades de desenvolvimento pessoal.

Esses mecanismos reforçados na formação do enfermeiro pelo modelo tradicional de ensino, criam resistências às mudanças, pois toda situação de mudança faz emergir os medos básicos que Pichon Riviére 
(2000) denomina de medo da perda e do ataque. No contexto de uma profissão onde a própria tarefa primária que é o cuidar é bastante ansiogênica. Seria importante que a formação profissional favorecesse 0 processo de auto-conhecimento e apoio para trabalhar, ainda que enquanto aluno, esses medos e ansiedades inerentes ao processo de cuidar de si e dos outros.

Segundo Angelo (1989), o significado da aprendizagem inicial em campo prático para o aluno ${ }^{1}$ de enfermagem revelou uma vivência difícil e frustrante permeada por interações significativas, processo este denominado pela autora como: "Vivendo uma prova de fogo". Em seu estudo, a autora descreve os primeiros contatos das alunas com a prática, sua relação com o campo, com os outros profissionais e pacientes, afirmando que no final desse processo, há a tomada de decisão entre a desistência e a continuidade do curso de graduação. O seu estudo conclui que o início da aprendizagem prática de enfermagem pode ser facilitado quando a aluna identifica ajuda na interação com a professora.

$\mathrm{Na}$ minha prática profissional como docente de curso de graduação, convivendo com alunos da primeira à quarta série, posso afirmar que ultrapassados estes primeiros conflitos, o aluno de enfermagem continua a se angustiar no processo de formação e a temer o que o espera na vida profissional.

\footnotetext{
${ }^{1}$ Embora grande parte do alunado sejam mulheres, optamos pelo gênero masculino.
} 
Caldeira (1997), em sua dissertação de Mestrado demonstra a necessidade que as escolas têm de inovar. Os alunos, na maioria das vezes buscam outras disciplinas em outros cursos, estágios e outras atividades extracurriculares, com o objetivo de enriquecerem sua formação e também como pessoa, procurando respostas à interrogações que lhes afligem, uma vez que o ensino proporcionado, quase sempre, é fragmentado, compartimentado, mantendo um hiato entre a teoria e a prática, com uma visão crítica da realidade, deslocada da realidade profissional.

Ciampone e Estivalet (2000), desenvolveram um trabalho envolvendo alunos do oitavo semestre do Curso de Graduação em Enfermagem, de uma Universidade Pública em São Paulo, onde os resultados revelam que nas situações por eles relatadas que envolviam o ser cuidado, evidenciaram falha dos docentes no apoio emocional, na continência, no saber ouvir, e no relacional com o aluno, prevalecendo a importância e o reforço dos aspectos técnicos envolvidos no ato do cuidado direcionado à clientela.

Oliveira, I. C. S et ali (2000), buscou compreender se a preparação para o trabalho do futuro enfermeiro tem se constituído num meio e instrumento de favorecimento do auto cuidado e ou da negação de si. Percebeu que o autoritarismo e a sobrecarga horária exigida no curso favorecem a negação de si. 
É inegável que a enfermagem, enquanto prática social e profissão da área da saúde, voltada principalmente para a dimensão do cuidado, vem ganhando espaço no mercado de trabalho nos âmbitos: da promoção à saúde, da prevenção de doenças, dos processos curativos e, também, na reabilitação, incluindo possibilidades de exercício profissional no campo hospitalar, nas unidades de saúde e no domicílio. Contudo, inúmeros trabalhos desenvolvidos nas últimas décadas têm evidenciado a importância do cuidador em relação ao como esse cuida do outro. Torna-se visível, porém, no cotidiano de trabalho nas instituições de saúde, o quanto o cuidador profissional, de modo geral, não valoriza o ser cuidado, muitas vezes negligenciando o cuidado à sua própria saúde.

A fragmentação dos processos de trabalho esgarçam as relações entre os diferentes profissionais da saúde e entre esses e usuários; o trabalho em equipe, bem como o preparo e disposição para lidarem com a dimensão subjetiva presente nas práticas de atuação em saúde, ficam bastante fragilizadas.

O trabalho em saúde é complexo e exige reflexão, ou seja, que as decisões sejam tomadas de modo articulado pelos vários saberes profissionais pautados em diferentes conhecimentos, mediados pelas dimensões ética e política.

Os novos modelos de produção de serviços, as necessidades dos consumidores, as estratégias de competitividade e de melhoria da qualidade nas empresas, exigem das instituições formadoras, 
compromissos de capacitação de pessoas em relação aos conhecimentos, destrezas, capacidade de realizar procedimentos englobando valores compatíveis com a lógica econômica predominante do mercado. (Santomé, 1998)

Torna-se fundamental ampliar a qualificação dos trabalhadores em saúde, seja na dimensão técnica (aprender a fazer e conhecer), como na dimensão ético-política (dimensão do aprender a conviver e ser), da comunicação, das inter-relações pessoais, viabilizando a atuação dos sujeitos de forma integral, diante das novas exigências do mercado profissional.

No contexto das políticas da educação brasileira, as mudanças vão refletir a partir da elaboração da LDB de 1996, Lei 9394/96. Permitiram-se contornos conceituais dos mais diversos onde surgiram várias propostas de reformas. Assegura ao Ensino Superior maior flexibilidade na organização curricular dos cursos, atendendo à necessidade de uma profunda revisão de toda a tradição que burocratiza os cursos e se revela incongruente com as tendências contemporâneas de considerar a formação em nível de graduação como uma etapa inicial da formação continuada.

Neste cenário, surge as Diretrizes Curriculares do Curso de

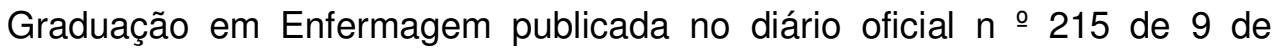
novembro de 2001. 
As diretrizes curriculares constituem:

Orientações para a elaboração dos currículos que devem ser necessariamente adotadas por todas as instituições de ensino superior. As diretrizes curriculares devem estimular o abandono das concepções antigas e herméticas das grades curriculares, de atuarem, muitas vezes, como meros instrumentos de transmissão de conhecimentos e informações, e garantir uma sólida formação básica, preparando o futuro graduado para enfrentar os desafios das rápidas transformações da sociedade, do mercado de trabalho e das condições de exercício profissional. (Parecer CNE/CES 1.133/2001).

As Diretrizes Curriculares dos Cursos de Graduação da Saúde tem definida como objeto, permitir que os currículos propostos possam construir perfil acadêmico e profissional com competências, habilidades e conteúdos, dentro de perspectivas nacionais e internacionais, capazes de atuar com qualidade, eficiência e resolutividade, no Sistema Único de Saúde (SUS). Considerando o processo de Reforma Sanitária Brasileira. Como objetivo, levar o aluno a aprender a aprender que engloba aprender a ser, aprender a fazer, aprender a viver juntos e aprender a conhecer, garantindo a capacitação de profissionais com autonomia e discernimento para assegurar a integralidade da atenção e a qualidade e humanização do atendimento prestado aos indivíduos, famílias e comunidades.

Com base neste contexto, a Comissão de Especialistas de Ensino de Enfermagem propõe as Diretrizes Curriculares, para a 
Enfermagem, onde se define a formação segundo os paradigmas de um perfil profissional crítico e reflexivo com competência técnica-ética-políticasocial-educativa que lhe permita atuar com segurança e propriedade tanto na promoção da saúde, como na prevenção e reabilitação, interagindo de forma efetiva com a sociedade, apresentando uma capacidade de liderança e muita sensibilidade para lidar com os problemas de saúde da comunidade. Almeja-se que o profissional possa trabalhar com equipes multidisciplinares e também em serviços socializados.

A discussão sobre o processo de formação dos cuidadores e profissionais é, portanto, fundamental. As Diretrizes para a Educação em Enfermagem no Brasil estão sendo amplamente discutidas pelas instituições formadoras que devem redefinir seus projetos políticos e pedagógicos.

Acredito que caminhamos para uma visão ampliada que contemple um projeto político pedagógico, que conceba o aluno como o principal ator, e o seu contexto de vida como parte do seu processo de ensino aprendizagem.

Partindo desses pressupostos, que apontam para a necessidade de projetos que envolvam o sistema formador como um espaço articulador de discussões a respeito de qualidade de vida, incluindo a do futuro profissional para o trabalho, justifica-se a elaboração da presente investigação. A hipótese formulada é que o objeto desse estudo - a formação dos profissionais enfermeiros, compreende o desenvolvimento de competências que envolvem uma permanente correlação e interação entre a 
dimensão pessoal/singular, profissional/particular e social/estrutural, que determinam e podem gerar, tanto processos de potencialização da qualidade de vida, como processos destrutivos da mesma, comprometendo a saúde física e mental do profissional e futuramente, a qualidade da assistência por eles prestada aos indivíduos, a famílias e comunidades Neste sentido, questiono: "A Universidade tem sido ou não um espaço para aprendizagem e vivência da qualidade de vida dos futuros enfermeiros?" 


\section{OBJETIVOS}

Considerando o processo de formação vivenciado, particularmente, dos alunos de graduação em enfermagem da PUC/SP e suas relações com a qualidade de vida, tenho como objetivos no presente estudo:

- Identificar quais as percepções que o aluno de graduação em enfermagem tem em relação a futura qualidade de vida no trabalho, tendo em vista as experiências vivenciadas no processo de formação.

Os objetivos específicos são:

- Identificar a compreensão que esses alunos têm sobre a própria qualidade de vida.

- Analisar as principais demandas por eles evidenciadas no resgate das situações vividas e os direcionamentos e estratégias de enfrentamento apontados que impactem na melhoria da sua qualidade de vida. 


\section{O REFERENCIAL TEÓRICO}

O presente capítulo descreve as bases conceituais e metodológicas que fundamentaram este estudo sobre a qualidade de vida na formação dos futuros enfermeiros.

Inicia-se por um breve resgate histórico do ensino de Enfermagem no país, visando situar o leitor quanto à historicidade e dinamicidade do processo de formação profissional do enfermeiro até os dias atuais.

Posteriormente, aborda-se a conceituação de qualidade de vida e das investigações que precederam os estudos contemporâneos sobre Qualidade de Vida no Trabalho.

A seguir, são discutidas as características específicas da Qualidade de Vida no Trabalho da Enfermagem, conceitos e modelos, na visão contemporânea.

Finalizando o capítulo, abordam-se estudos realizados sobre a Qualidade de Vida dos Estudantes de Enfermagem. 


\subsection{O Contexto Histórico do Ensino da Enfermagem no Brasil}

A primeira tentativa de organização do ensino de enfermagem data de 1890, após cinqüenta anos da criação do primeiro hospital psiquiátrico no Brasil, pela Instituição de uma Escola Profissional de Enfermeiros e Enfermeiras, criada pelo Decreto $n^{\circ} 791$, de 27 de setembro de 1890 ( Ministério da Saúde, 1974).

Este Decreto estabelecia que fosse instituída uma escola destinada a preparar enfermeiros para os hospícios e hospitais civis e militares. A criação dessa Escola de Enfermagem justificou-se pela deficiência de pessoal na assistência aos insanos, uma vez que as Irmãs de Caridade, que detinham todo o poder nessas Instituições, abandonaram o hospício, quando se sentiram excluídas do poder por ocasião da Proclamação da República (1889), momento no qual ocorre uma ruptura entre os cuidados dirigidos pela Igreja e pelo Estado, fato que ocasionou redirecionamento da assistência aos doentes mentais. Nessa circunstância, os médicos assumiram o poder nas Instituições, o que fez com que as relações com as religiosas se tornassem insustentáveis.

Segundo Germano (1985), em 1890, acontece o marco inicial do ensino, quando há a criação de uma Escola de Enfermagem no Rio de Janeiro, a Escola Alfredo Pinto, que nasce no Hospital Nacional dos Alienados, tendo como finalidade a formação de pessoal para atuar em psiquiatria. Neste momento, as Irmãs de Caridade haviam deixado o 
hospital, por se sentirem cerceadas em muitas de suas atribuições, pela nova direção. Essa Escola foi inspirada numa escola francesa - Escola de Salpetrière - embora a direção por enfermeira somente tenha ocorrido após mais de 50 anos de sua existência, em 1943.

Se esta primeira escola nasceu dentro de um hospício para atender a pacientes portadores de distúrbios mentais, considerados como grupo de perturbadores da ordem da sociedade da época, outras que continuaram a surgir também tinham claros seus objetivos. O curso de enfermagem instalado no Hospital Evangélico, hoje Hospital Samaritano, em São Paulo, por volta de 1901, foi fundado para "preparar pessoal para esta instituição", as alunas eram oriundas de famílias estrangeiras do Sul do país, as aulas eram ministradas em inglês e o referido hospital destinava-se ao atendimento de estrangeiros (Germano, 1985).

A Escola de Enfermagem da Cruz Vermelha, no Rio de Janeiro, surgiu em 1916, fruto das repercussões das 1르 Guerra Mundial, com o objetivo de " formar enfermeiras para assistência caritativa e voluntários para as emergências de guerra", filosofia esta característica da Instituição Cruz Vermelha. Já o curso de formação de enfermeiros do Exército aparece na história da enfermagem amparado legalmente em 1921, com o objetivo de "preparar pessoal de enfermagem para atuar nos hospitais militares existentes no Brasil desde o século XVII" (Pires, 1989).

Na década de 20, houve outra tentativa de organização do ensino de enfermagem e, segundo Germano (1985), é nesse momento que 
nasce a enfermagem moderna no Brasil, sob a égide da saúde pública. Com a implantação do modelo Nightingale na Escola de Enfermagem do Departamento Nacional de Saúde Pública, atual Ana Néri, a formação dos enfermeiros voltou-se para a saúde pública. Essa foi a primeira escola no Brasil a ter enfermeiras ministrando o ensino sistematizado de enfermagem, tendo sido considerada como escola oficial padrão para todo o país, com organização administrativa e docente, segundo legislação vigente na época.

Inicialmente, a Escola Ana Néri foi considerada instituição complementar da Universidade do Brasil, conforme Lei $n^{\circ} 452$ de 05 de julho de 1937, passando definitivamente a pertencer à Universidade do Brasil, embora sem a condição de instituição complementar, de acordo com o Decreto n²1.321 de 18 de junho de 1946 da Presidência da República ( Ministério da Saúde, 1974).

Os primeiros cursos tinham caráter intensivo, com duração de 28 meses e, em seguida, 32, respectivamente. Exigia-se do candidato a conclusão do curso normal ou equivalente, diferentemente, das escolas da época (Cruz Vermelha e Alfredo Pinto), cujas exigências restringiam-se apenas a saber ler e escrever (Germano, 1985).

Em relação ao currículo de enfermagem, este continuou inalterado durante o período compreendido entre 1923 e 1949, quando, então, sofreu a primeira reformulação.

O ensino de enfermagem passou a ser regulado pela Lei $\mathrm{n}^{\circ}$ 775/49, regulamentada pelo Decreto n²7.426/49 (Ministério da Saúde, 
1974), que dispõe sobre o currículo dos cursos e as condições de preparação de enfermeiros, estipulando a duração de quatro anos e a exigência de conclusão do curso colegial.

Em 1961, com a Lei $\mathrm{n}^{\circ} 2.604 / 55$, regulamentada pelo Decreto $n^{\circ}$ 50.387/61 (Ministério da Saúde, 1974), sobre o exercício da enfermagem, deu-se ao enfermeiro o poder de comando em relação aos auxiliares e atendentes de enfermagem e aos cuidados de enfermagem. Nesse momento, ocorreu a passagem definitiva dos cursos de enfermagem para o nível superior, em obediência ao disposto na Lei n².995/56.

Em seguida, o Conselho Nacional de Educação -CFEbaixou o Parecer n²71/62 (Ministério da Saúde, 1974), que fixou o currículo mínimo e determinou a duração mínima de três anos para o Curso de Enfermagem.

Comparando os currículos do Curso de Enfermagem de 1949 e o de 1962, Germano (1985) mostra uma significativa mudança, quando relaciona que o primeiro surge numa fase em que prevalecia uma política supostamente liberal, na vigência de um capitalismo que ainda não concebia a privatização da saúde de forma empresarial, privilegiando, por conseguinte, o estudo das doenças coletivas, por meio das disciplinas ditas da área preventiva. O segundo emerge num momento em que a economia brasileira começou tender para um processo excludente e concentrador de renda e, dessa forma, a preocupação primordial do currículo de enfermagem 
passa então a privilegiar conteúdos das clínicas especializadas, de caráter curativo.

Com esta ênfase, o ensino de enfermagem prosseguiu até o início da década de 70, quando em 1972, foi aprovado o Parecer CFE n 163/72 (Ministério da Saúde, 1974), como conseqüência da reforma universitária, definindo como carga mínima curricular, 2500 horas.

No ano de 1986, com a aprovação da nova Lei do Exercício Profissional em Enfermagem, Lei $\mathrm{n}^{\circ} 7.498 / 86$ (Brasil, 1986), destaca-se, a importância do ensino na formação do enfermeiro, ao enfatizar o papel do enfermeiro como educador e como integrante da equipe de saúde, explicitando, no enunciado da Lei que: "ao enfermeiro cabe participar dos programas de treinamento e aprimoramento do pessoal de saúde, especialmente dos programas de educação continuada e a educação visando à melhoria de saúde da população".

Em 1994, foi aprovada a Portaria MEC $n^{\circ} 1.721 / 94$ que regulamenta o ensino dos Cursos de Graduação em Enfermagem, passando o currículo a compreender uma carga horária de 3500 horas, com duração mínima de 4 anos.

Em 1996, em virtude da nova Lei de Diretrizes e Bases da Educação Nacional - Lei $n^{\circ}$ 9394, de 20 de dezembro de 1996, na qual ocorrem inovações e mudanças na educação nacional, é assegurada às instituições de ensino superior autonomia didático-pedagógica, bem como liberdade em fixar os currículos dos seus programas. Como diretrizes gerais 
para a educação dos profissionais do século XXI, enfatiza-se que todos os profissionais de saúde deverão estar dotados de competências que possibilitem sua interação e atuação multiprofissional, respeitando a especificidade de cada profissão. Dentre as competências, previstas nas Diretrizes Curriculares Nacionais, destacam-se: Atenção à saúde; Tomada de Decisão; Comunicação; Liderança; Administração e Gerenciamento; e Educação Permanente.

É interessante ressaltar, que o Ensino de Enfermagem, independente da época, sempre impôs aos futuros profissionais uma rotina onde esta presente alto grau de tensão, queixas constantes dos pacientes, ansiedade, tristeza, dor, morte e longos períodos de dedicação ao trabalho, com rodízios de turnos e duplas jornadas de trabalho devido à baixa remuneração.

O legado de Florence Nightingale, sem dúvidas se fez presente na formação profissional da enfermagem, e foi marcado por uma dualidade: "disciplina, autoritarismo, e organização por um lado; e obediência, servilismo e docilidade, por outro lado." (Waldow, 1998, p.54)

Tais características, que marcaram e, marcam ainda, em maior ou menor intensidade, a formação dos enfermeiros são evidenciadas pela abnegação do eu, pela renúncia dos sentimentos e da vontade própria.

Portanto, o processo de formação do enfermeiro foi forjado por essas características presentes nas práticas profissionais acrescido, ainda, por exigências de excelência técnica, fundamentada no modelo 
biológico, sem que fosse dada a mesma importância para os processos relacionais.

As competências técnico-científicas e interpessoais, posteriormente incorporadas à formação, são predominantemente desenvolvidas e direcionadas para o atendimento ao cliente, família e/ou comunidade, enfim, direcionada ao cuidado outro, negligenciando as necessidades pessoais do cuidado de si mesmo.

Apesar da riqueza de oportunidades que a formação em enfermagem oferece pelo contato com pessoas e suas experiências que poderiam ser propícias ao conhecimento de si, enquanto profissional cuidador, e do reflexo das atitudes próprias nos relacionamentos interpessoais, os currículos, em geral, não oferecem espaços para o autoconhecimento e aprimoramento dos processos relacionais, ação esta que permitiria elaboração das ações e conseqüente desenvolvimento profissional e pessoal.

Apesar da dinamicidade do processo de mudanças que vem ocorrendo no ensino de enfermagem, é necessário que os alunos de enfermagem sejam incentivados e orientados para o cuidado de si mesmos para que cresçam não somente como profissionais, mas como pessoas.

Desse modo as instituições formadoras necessitam aprimorar as metodologias e estratégias de ensino relacionadas ao cuidado de si, incluindo nesse contexto aspectos relativos à promoção da qualidade de vida dos alunos. 


\subsection{Qualidade de vida. Os diferentes conceitos}

Inicialmente, é importante destacar que os estudos sobre qualidade de vida são tratados sob diferentes enfoques, seja do ponto de vista objetivo (satisfação das necessidades básicas e das necessidades criadas pelo grau de desenvolvimento econômico e social de determinada sociedade) ou subjetivo (bem-estar, felicidade, amor, prazer, realização pessoal), focando os âmbitos individual ou coletivo.

É de consenso entre os autores, que embora o termo qualidade de vida tenha sido amplamente utilizado nos últimos anos, ainda hoje inexiste uma definição aceita universalmente, variando esta de autor para autor, a depender do enfoque privilegiado, Gaíva (1998).

Flanagan (1982), cita que os primeiros esforços para medir qualidade de vida começaram com o Relatório da Comissão Nacional de Metas do presidente Eisenhower, publicado em 1960, incluíndo dentre as variáveis que influenciam a qualidade de vida, uma variedade de fatores tais como: educação, interesse individual, crescimento econômico, saúde e bem estar e liberdade.

Com o final da segunda grande guerra mundial, a Organização das Nações Unidas (ONU), preocupada com as condições de vida da população nos países membros, faz uma recomendação para que fossem estudados as variáveis que interferiam nessas condições. Assim, surgem na década de 50, diferentes investigadores: clínicos, 
epidemiologistas, cientistas sociais e estatísticos, conduzindo pesquisas de medidas de atributos humanos, denominados de "boa vida".

O conceito de "boa vida" foi usado para se referir à conquista de bens materiais: possuir casa própria, carro, aparelhos eletrônicos etc. Esse conceito foi posteriormente ampliado, para medir o quanto uma sociedade havia se desenvolvido economicamente, não importando se tal riqueza estava distribuída de modo equitativo.

As pesquisas de cunho social e econômico predominaram nessa área do conhecimento e o primeiro referencial importante, correlacionou qualidade de vida ao Produto Interno Bruto (PIB) dos países como indicador de "boa vida".

Fleck et al.(1999) destacam que tal aspecto foi criticado por muitos cientistas sociais que salientam que, a riqueza medida pelo PIB, não era indicador de distribuição equanimente. Esta crítica ganha notoriedade quando em um discurso o presidente dos Estados Unidos, Lyndon Johnson, em 1964, emprega a expressão qualidade de vida ao afirmar que "os objetivos (de bem estar da população) não podem ser medidos através do balanço dos bancos. Eles só podem ser medidos através da qualidade de vida que estes proporcionam às pessoas".

No entanto, a idéia de qualidade de vida foi pouco explorada na literatura até 1975, quando pesquisadores começaram a investigar os atributos que fazem parte da qualidade de vida, bem como os instrumentos que poderiam ser desenvolvidos para mensurar esses atributos e gerar 
diagnósticos e intervenções que poderiam ajudar a reduzir os fatores que impactam desfavoravelmente na qualidade de vida (Goodinson et al, 1989).

Becker et al (1993), salientam que alguns fatores para a avaliação da qualidade de vida são: ambiente, moradia, divertimento, alimentação, roupas e serviços de saúde mental. Argumentam que, em pesquisas anteriores, as pessoas responderam às questões sobre qualidade de vida baseadas em percepções das situações relacionadas àquilo que Ihes dava satisfação.

Para Lentz e col.(2000), a qualidade de vida é algo complexo para ser definido e a sua conceituação, ponderação e valorização, vem sofrendo modificações, que por certo acompanham a dinâmica da evolução da humanidade, nas diferentes culturas e crenças, que determinam diferentes prioridades relacionadas à qualidade de vida.

Minayo et al (2000), referem que, o discurso que estabelece a correlação entre qualidade de vida e saúde, embora bastante inespecífico na medicina social dos séculos XVIII e XIX, foram gerando investigações sistemáticas que começaram a frutificar dando subsídios para o estabelecimento de políticas públicas e movimentos sociais em favor do desenvolvimento de qualidade de vida das populações. O estudo da situação da classe trabalhadora na Inglaterra, desenvolvido por Engels, ou da Mortalidade diferencial na França, conduzido por Villermé, ambas citados por Rosen (1980), são exemplos da mudança de correlação entre qualidade de vida e saúde. 
A idéia de estabelecer a relação entre qualidade de vida e saúde, atravessa toda a história da medicina social ocidental e também latino-americana, como mostram os trabalhos de Mckeown (1982), Breilh et a.I. (1990), Nunez (1994) e Paim (1994). De fato, nesses estudos, em sua maioria, o termo de referência não é qualidade de vida, mas sim, condições de vida.(Minayo et al,2000)

Breihl (1986) concebe o processo saúde-doença como a "síntese do conjunto de determinações que operam numa sociedade concreta, produzindo nos diferentes grupos sociais o aparecimento de riscos ou potencialidades que Ihes são característicos. Estes, por sua vez, são manifestos na forma de perfis ou padrões de doença ou saúde. Certamente, a qualidade de vida á qual cada grupo sócio-econômico está exposto é diferente pois, igualmente diferente é a sua exposição a processos de risco que produzem o aparecimento de doenças e formas de morte específicas, assim como o acesso a processos benéficos ou potencializadores da saúde e da vida".

Portanto, em um dado modo de produção, situa-se um processo de reprodução social que se concretiza em uma dada formação social. Esta formação social determina a existência de uma estrutura de classes sociais e de relações entre estas. A dinâmica de classes implica em uma relação unitária entre produção e consumo. Nesta dialética a produção não acontece na ausência do consumo, e o consumo depende da produção. 
A determinação do processo biopsicossocial coletivo nas diferentes classes sociais é mediado, assim, pelos processos de produção e de consumo.

No que se refere à produção, a inserção dos agentes sociais em processos concretos de trabalho, determina não somente sua própria exposição a riscos ocupacionais específicos como também, determina o seu acesso à riqueza ali produzida, através de seus rendimentos. Esses rendimentos, por sua vez, determinam os níveis de consumo e, portanto, o acesso a bens materiais de vida que incluem entre outros, alimentação, moradia, saneamento, assistência médica, escolaridade, etc.

Isso posto, é através da dialética produção-consumo, que é possível entender os perfis diferenciais de saúde-doença entre os grupos sociais e dentro de cada grupo específico.

Fleck et al.(1999) considera que a preocupação com o conceito de "qualidade de vida" refere-se a um movimento dentro das ciências humanas e biológicas, no sentido de valorizar parâmetros mais amplos do que o controle de sintomas, diminuição da mortalidade ou o aumento da expectativa de vida.

Gaíva (1998) admite que as várias áreas de saúde têm utilizado diferentes medidas de "Qualidade de Vida" para avaliar e predizer o impacto de determinadas enfermidades na população em geral, no sentido de obter uma visão integral do indivíduo e sua resposta à enfermidade. 
Os estudos preponderantes sobre "Qualidade de Vida" buscam relacionar a saúde com avaliações de indivíduos que vivenciam diferentes doenças crônicas que, muitas vezes, podem alterar as condições objetivas/subjetivas de vida do indivíduo e da família, já que a forma como estes vivenciam estas transformações, pode tornar-se um fator de agudização ou de melhoria do seu estado geral. Gaíva, (1998).

Assim, ao falarmos de qualidade de vida, é necessário assumirmos uma postura multidimensional, visto que são muitos os fatores que estão relacionados com a vida.

Um aumento do interesse em pesquisar sobre qualidade de vida, evidencia-se pelo grande número de investigações, desenvolvidas nessas últimas décadas. Trabalhos sobre esse tema abundam na base de dados MEDLINE que reúne hoje 44. 415 artigos publicados, no período de 1966 até a presente data.

Com extenso número de publicações e centros de pesquisas envolvidos nas mesmas, não é de se estranhar que surgissem muitos conceitos e instrumentos para avaliar a qualidade de vida. Essa diversidade apresenta seus benefícios, mas também causa problemas dado às limitações inerentes aos instrumentos. A coexistência de conceitos variáveis e sem consenso, levaram a Organização das Nações Unidas (ONU), através da Organização Mundial da Saúde (OMS), a criar um grupo de trabalho que objetivou construir maior proximidade conceitual. Para tanto, esse grupo reuniu-se, a partir do final da década de 80 , contando com especialistas de 
diferentes áreas e de 15 diferentes contextos culturais, condições sóciopolíticas, econômicas e credos, tendo como missão produzir um conceito e um instrumento para avaliação da Qualidade de Vida (Fleck, 1999).

O resultado destes encontros permitiu chegar ao conceito de Qualidade de Vida como: "a percepção do indivíduo quanto a sua posição na vida e no contexto da cultura e sistema de valores, nos quais ele vive e em relação aos seus próprios objetivos, expectativas, padrões e preocupações" (Fleck,1999).

\subsubsection{Qualidade de vida no trabalho e qualidade de vida dos trabalhadores de enfermagem.}

Antecedendo a apresentação de alguns dos conceitos de qualidade de vida no trabalho (QVT), optamos por discorrer sobre alguns estudos que precederam a conceituação desse termo.

Estudos realizados sobre as Teorias de Administração, principalmente a Teoria das Relações Humanas e a Teoria Comportamentalista mostram a evolução do pensamento científico em diferentes períodos e a valorização crescente sobre o conhecimento do comportamento humano no trabalho e focalizando os aspectos humanos relacionados ao trabalhador, que influenciam diretamente no produto final do trabalho. 
É de consenso entre autores da área de Administração que, os estudos realizados por Mayo, Maslow, McGregor, Herzberg e McClelland, servem de base para os novos enfoques ou teorias sobre o comportamento do indivíduo quando no desempenho de atividades produtivas e de sua Qualidade de Vida no Trabalho.

Chiavenato (2000) classifica Mayo como um autor cuja abordagem está centrada na fase humanista da história da Administração influenciando a criação da Teoria das Relações Humanas; enquanto Maslow, McGregor, McClelland e Herzberg enquadram-se na abordagem behavorista ou comportamental da Administração - gerando a Teoria Comportamentalista.

A compreensão da integração dessas teorias é fundamental, pois constituem o suporte teórico para o embasamento de conceitos e medidas de Qualidade de Vida no trabalho.

Embora não seja o foco dessa pesquisa, optamos por destacar alguns aspectos fundamentais da Teoria das Relações Humanas, originada pela Experiência de Hawthorne, de Elton Mayo, considerado o principal autor desta teoria.

\subsubsection{A Experiência de Hawthorne}

George Elton Mayo, australiano, psicólogo, cientista social e pesquisador da Harvard Graduate School of Business Administration, no 
início da década de 20 do século passado, desenvolveu, ao lado de seus colaboradores, os primeiros estudos sobre o comportamento humano no trabalho, que deram origem à Teoria das Relações Humanas ou Escola Humanística da Administração, em decorrência das conclusões obtidas pela Experiência de Hawthorne. (Chiavenato,2000)

Destaca-se que os estudos de Mayo, surgiram devido à necessidade de humanização e democratização na eminência do trabalho industrial, marcado pelos pressupostos rígidos e mecanicistas das teorias precedentes, Científica e Clássica. Nesse período, o desenvolvimento do conhecimento das ciências humanas, principalmente da psicologia e sociologia influenciam as concepções sobre o trabalho nas organizações industriais.

Embora a Experiência de Hawthorne tenha sido apontada pelos autores como o primeiro experimento que buscou correlacionar a influência das condições físicas do ambiente de trabalho, sobre a produtividade do indivíduo, Elton Mayo, um pouco antes, conduziu uma pesquisa em uma empresa têxtil americana que possuía um índice de $250 \%$ de rotatividade de pessoal por ano e que já havia tentado estabilizar tal índice inutilmente com incentivos salariais. Mayo, em pouco tempo, conseguiu reduzir este índice ao introduzir um intervalo de descanso e delegar aos funcionários a decisão sobre seus horários de trabalho.

Em 1927, Mayo, começou a coordenar a pesquisa na fábrica de Hawthorne da Western Eletric Company, que produzia equipamentos e 
componentes telefônicos, situada em Chicago. O primeiro objetivo do estudo era avaliar os efeitos da fadiga e da monotonia nos resultados da produção.

Posteriormente, Mayo e seus colaboradores, continuam a pesquisa, com o intuito de fazer um levantamento das atitudes e anseios dos trabalhadores, utilizando, para tanto, um método baseado em entrevistas.

Os experimentos prosseguiram até 1932, quando, por motivos econômicos e psicológicos provocados pela recessão, tiveram de ser interrompidos.

Algumas críticas foram feitas ao trabalho de Mayo, quanto à metodologia e à parcialidade dos resultados obtidos, à identificação de problemas, sem propor soluções e além disso por poderem ser generalizados tendo em vista a não representatividade quanto aos grupos estudados na empresa como um todo.

Mesmo diante das limitações apontadas na pesquisa de Mayo, não se pode negar o pioneirismo de seu trabalho e que este, em muito contribuiu e vem contribuindo para os estudos sobre o comportamento humano no trabalho e qualidade de vida do trabalhador.

A seguir, discutimos os principais estudos de autores que marcaram a Segunda teoria, a Comportamentalista, cujos pressupostos também oferecem suporte aos modelos de QVT, encontrados na literatura.

A Teoria Comportamentalista, também conhecida por Behavorista, segundo Chiavenato (2000), "marca a mais forte influência das 
ciências do comportamento na teoria administrativa e a busca de novas soluções democráticas, humanas e flexíveis para os problemas organizacionais".

A motivação humana passou a ser objeto de estudos na Administração através da Teoria Comportamentalista, tida como um desdobramento da Teoria das Relações Humanas. Chiavenato (2000) afirma a importância dos administradores conhecerem as necessidades humanas para melhor compreenderem o comportamento humano e a motivação como meio para melhorar a produtividade e a qualidade de vida dentro das organizações.

\subsubsection{A Teoria da Hierarquia das Necessidades}

Abraham Maslow foi o "primeiro a relacionar as necessidades humanas num quadro teórico abrangente definindo a teoria da motivação humana, baseada numa hierarquia das necessidades humanas básicas" (Rodrigues, 1994).

O trabalho de Maslow, serviu de apoio à outros cientistas sociais, tal como Douglas Mc Gregor na análise das condições de vida e necessidades do indivíduo no trabalho.

A "hierarquia das necessidades" de Maslow é composta por cinco necessidades fundamentais: fisiológicas, segurança, amor, estima e auto realização. Inicialmente, o autor propõe uma escala hierarquizada e 
seqüencial dessas necessidades. Posteriormente, o autor admite uma flexibilidade, no sentido de que, para surgir uma nova necessidade, não é necessário que uma necessidade anterior esteja 100\% satisfeita. O autor considera ainda, que a maioria das pessoas normais em nossa sociedade se encontram parcialmente satisfeitas e parcialmente insatisfeitas, em relação às suas necessidades fundamentais.

Explica que as "necessidades" podem surgir de forma consciente e inconsciente, sendo que esta última forma é a forma mais frequente.

Sabe-se, ainda que várias pesquisas não chegaram a confirmar cientificamente a Teoria de Maslow e que, algumas delas até mesmo a invalidam. No entanto, considera-se que ela é suficientemente bem estruturada para poder oferecer um esquema orientador e útil para análise do comportamento humano.

Um estudo mais recente, feito por Bertoni (1994) revela que os conceitos de Maslow foram distorcidos, na década de 70, pelos teóricos da Administração e reapresenta os conceitos divulgados nos livros acrescentando a eles uma sexta necessidade, chamada por Maslow de “meta - necessidade", que não foi, até então, abordada pelos teóricos.

Com o intuito de facilitar a compreensão, apresentamos um quadro síntese dos conceitos de Maslow, conforme descritos por Bertoni (1994) e a interpretação destes de acordo com a visão da Administração na década de 70 . 
Quadro 1: $\quad$ Síntese os conceitos de Maslow descritos Bertoni (1994) e os utilizados pela Administração na década de 70.

\begin{tabular}{|c|c|}
\hline CONCEITOS DE MASLOW & $\begin{array}{l}\text { INTERPRETAÇÃO DOS CONCEITOS } \\
\text { UTILIZADOS PELA ADMINISTRAÇÃO/ } \\
\text { ANOS } 70\end{array}$ \\
\hline $\begin{array}{l}\text { Necessidades: os " motivos para viver", ou seja, } \\
\text { as necessidades humanas constituem os } \\
\text { motivos que o indivíduo tem para viver, conceito } \\
\text { este associado às fases da vida. }\end{array}$ & $\begin{array}{l}\text { Este conceito é estático, aparecendo } \\
\text { apenas como uma necessidade externa do } \\
\text { indivíduo. }\end{array}$ \\
\hline $\begin{array}{l}\text { 1. Necessidades fisiológicas: Integração } \\
\text { (corpo), Psio } \\
\text { indivíduo, cuja desintegração leva) e leva } \\
\text { desequilíbrio. }\end{array}$ & $\begin{array}{l}\text { 1. Estas necessidades são definidas apenas } \\
\text { como condições de satisfazer ou não a } \\
\text { fome, sede, abrigo e sexo. }\end{array}$ \\
\hline $\begin{array}{l}\text { 2. Necessidade de segurança: refere-se à } \\
\text { obtenção de conhecimento e capacidade do } \\
\text { indivíduo para exercer um trabalho com auto- } \\
\text { estima. }\end{array}$ & $\begin{array}{l}\text { 2. Aquisição de bens materiais e a } \\
\text { preocupação com benefícios e estabilidade. }\end{array}$ \\
\hline $\begin{array}{l}\text { 3. Necessidade social: "sociabilidade" = } \\
\text { compartilhar, aprofundar e disseminar } \\
\text { conhecimentos e experiências dos indivíduos } \\
\text { com seus pares. }\end{array}$ & $\begin{array}{l}\text { 3. A integração limitou-se á participação do } \\
\text { indivíduo em grupos sociais, esportivos, } \\
\text { religiosos e de bairros. }\end{array}$ \\
\hline $\begin{array}{l}\text { 4. Necessidade de auto-estima: capacidade do } \\
\text { indivíduo de criar novos métodos e técnicas, de } \\
\text { inovar, de sugerir novas formas de ação. }\end{array}$ & $\begin{array}{l}\text { 4. Obtenção de "status", a promoção da } \\
\text { hierarquia funcional da empresa, a } \\
\text { reputação, o domínio, o poder e o prestigio } \\
\text { adquiridos. }\end{array}$ \\
\hline $\begin{array}{l}\text { 5. Necessidade de auto-realização: refere-se ao } \\
\text { ato de consolidar o processo de alcance de } \\
\text { objetivos de uma etapa evolutiva de vida ("Peak } \\
\text { Experiences") e que são várias vezes } \\
\text { alcançáveis na vida. }\end{array}$ & $\begin{array}{l}\text { 5. Liberdade e a tranquilidade para tomar } \\
\text { decisões. }\end{array}$ \\
\hline $\begin{array}{l}\text { 6. "Meta-necessidade": trata-se de uma } \\
\text { necessidade que independe da hierarquia, ou } \\
\text { seja, significa verdade, justiça e amor que } \\
\text { constituem os pressupostos básicos para o } \\
\text { funcionamento de uma organização saudável. }\end{array}$ & $\begin{array}{l}\text { 6. Não é citada pelos autores da } \\
\text { administração. }\end{array}$ \\
\hline
\end{tabular}

Sobre a Teoria de Maslow, pode-se concluir que a satisfação

ou não de uma ou mais necessidades, gera no indivíduo um impulso que o

move em direção à adoção de um comportamento, ou seja, gera um motivo

para a realização de ações satisfatórias, servindo como apoio para explicar

as reações das pessoas frente à diversidade de forças motivacionais. 
Entretanto, reconhece-se que o ciclo necessidade/comportamento constitui um dos fatores que induzem as ações das pessoas, desse modo, este ciclo também é reconhecido como um dos fatores mais significativos para a análise da qualidade de vida no trabalho.

\subsubsection{Mc Gregor: uma proposta de satisfação no trabalho.}

Ao analisar o comportamento do indivíduo no trabalho, McGregor, (1980) afirma que a empresa tradicional oferece "poucas oportunidades de satisfação das necessidades egoístas, principalmente para as pessoas situadas nos níveis inferiores da hierarquia"(p.45). Chamou de necessidades egoístas aquelas que englobam a auto-estima (auto-respeito e confiança, autonomia, realização, competência e conhecimento) e a própria reputação ( "status", reconhecimento e aprovação).

As necessidades egoístas, para McGregor, são atendidas fora do local de trabalho, pois acreditava-se que apenas as necessidades básicas, sistematizadas por Maslow, eram satisfeitas no local de trabalho, em função das empresa oferecerem não oferecerem condições para tal. Isto levava as pessoas a adotarem um comportamento indolente, passivo, com má vontade de assumirem responsabilidades, resistentes às mudanças e exigentes quanto aos benefícios financeiros percebidos. 
Tais pressupostos caracterizam o estilo tradicional de administrar, próprio da administração científica, atualmente muito criticada por seu exagerado mecanismo e pragmatismo.

No intuito de justificar tais comportamentos humanos e organizacionais, McGregor agrupou as idéias relacionadas a um padrão de comportamento do indivíduo, no trabalho, decorrentes da administração científica, e denominou-os de Teoria X. Os pressupostos que deram origem a esta teoria são apresentados pelo autor como segue (McGregor, 1980):

“1. O ser humano, de modo geral, tem aversão essencial ao trabalho e o evita sempre que possível;

2. Devido a essas características humanas de aversão ao trabalho a maioria das pessoas precisa ser coagida, controlada, dirigida, ameaçada de punição para que se esforce no sentido da consecução dos objetivos organizacionais;

3. O ser humano, de modo geral, prefere ser dirigido, quer evitar responsabilidade, tem relativamente pouca ambição e quer garantia acima de tudo" ( McGregor, 1980, p. 41-42).

O autor propõe, então, uma outra forma de perceber os indivíduos na organização e denomina essa forma de Teoria $\mathrm{Y}$, cujas pressuposições principais são:

"1. O dispêndio de esforço físico e mental no trabalho é tão natural como o jogo ou o descanso; 
2.0 controle externo e a ameaça de punição são os únicos meios de estimular o trabalho em vista dos objetivos organizacionais. $O$ homem está sempre disposto a se autodirigir e se autocontrolar a serviço de objetivos com os quais se compromete;

3. O compromisso com os objetivos é dependente das recompensas associadas a sua consecução;

4. O ser humano comum aprende, sob condições adequadas, não só a aceitar responsabilidades como a procurálas;

5. A capacidade de usar um grau relativamente alto de imaginação, de engenhosidade e de criatividade na solução de problemas organizacionais é mais amplamente distribuída na população do que geralmente se pensa;

\footnotetext{
6. Nas condições da vida industrial moderna, as potencialidades intelectuais do ser humano estão sendo parcialmente usadas" (McGregor, 1980,p.53).
}

Com esta Teoria, o autor propõe que, se ofereçam condições aos indivíduos para que as necessidades atendidas, até então apenas fora do local de trabalho passem, também, a serem satisfeitas no mesmo. Esta Teoria impulsionou a operacionalização de propostas que propiciaram um grande avanço na produtividade e na qualidade de vida do indivíduo no trabalho. 


\subsubsection{A Teoria dos Dois Fatores}

A teoria da motivação de Frederick Herzberg foi formulada com base em um estudo empírico, realizado, inicialmente, com 200 engenheiros e contadores de nove indústrias de fabricação de metais localizadas em Pittsburgh.

Herzberg (1964) levantou a hipótese dos "dois fatores" que sugeria que os fatores que produziam satisfação no trabalho são distintos daqueles que produziam a insatisfação. O autor, em sua hipótese, considera que os fatores que produzem satisfação no trabalho seriam distintos daqueles que produzem a insatisfação; e que o oposto da satisfação no trabalho não seria a insatisfação, e sim, nenhuma satisfação; por outro lado, o oposto de insatisfação não seria a satisfação, e sim, nenhuma insatisfação no trabalho.

Os fatores capazes de produzir insatisfação foram denominados pelo autor de "fatores higiênicos", por terem uma analogia à medicina preventiva por sua característica profilática; e a segunda categoria de fatores foi por ele chamada de "fatores motivacionais", porque Ihe pareciam eficazes para motivar as pessoas no desempenho de suas atividades de trabalho.

Os fatores higiênicos incluem: as condições físicas, ambientais e de segurança no trabalho, as políticas e diretrizes da empresa, 
o relacionamento entre o chefe ou supervisor com seus subordinados, o salário e os benefícios.

Os fatores motivacionais envolvem os sentimentos de crescimento individual, o reconhecimento profissional e a auto-realização e dependem das tarefas que o indivíduo realiza no trabalho.

Herzberg (1968) propõe que os fatores motivacionais sejam concebidos pelas empresas a partir do "enriquecimento do cargo" (job enrichment), que consiste em substituir tarefas simples por tarefas mais complexas que acompanhem o crescimento individual das pessoas, oferecendo-Ihes condições para o seu desenvolvimento psicológico e para a sua realização profissional.

Pode-se concluir que a Teoria dos Dois Fatores de Frederick Herzberg trouxe um novo enfoque sobre a motivação humana no trabalho, tendo em vista suas principais conclusões, ou seja, que a satisfação no trabalho não é um conceito unidirecional, e sim, que pode ser representada por dois contínuos, assim compreendidos: desde a alta satisfação no trabalho, até nenhuma satisfação no trabalho; e desde nenhuma insatisfação no trabalho, até a alta insatisfação; além da adoção do enriquecimento do cargo, que para os estudiosos de Qualidade de Vida no Trabalho possuiu um inestimável valor. 


\subsubsection{A Teoria das Necessidades Aprendidas}

David C. McClelland propôs a teoria sobre a motivação humana para o trabalho, partindo de pressupostos relacionados a conceitos de aprendizagem, pois acreditava que muitas necessidades são aprendidas pelo indivíduo quando enfrenta o meio, em função de sua cultura (Chiavenato,2000).

Essa teoria compreende três necessidades: a necessidade de realização, a necessidade de afiliação e a necessidade de poder.

Por necessidade de realização, entende McClelland que as pessoas gostam de ter responsabilidade para resolver problemas, tendem a traçar metas moderadas para a própria realização e inclinam-se a correr riscos calculados, além de desejarem obter feedback sobre o seu desempenho.

No que se refere à necessidade de afiliação, o autor diz que esta reflete 0 desejo das pessoas em interagirem socialmente e a preocupação com a qualidade de suas relações sociais; sendo assim, para uma pessoa com grande necessidade de afiliação, o relacionamento social precede as tarefas orientadas para a realização.

Quanto à pessoa que tem grande necessidade de poder, esta se concentra na obtenção e exercício do poder e da autoridade, procurando influenciar e vencer as outras pessoas pela argumentação. Isto se dá sob duas orientações possíveis: a positiva, quando reflete um 
comportamento persuasivo e inspirador; e a negativa quando a pessoa procura dominar e submeter as demais.

O autor afirma que o comportamento recompensado tende a se repetir frequentemente, pois a grande necessidade de realização, afiliação ou de poder apresentada pelas pessoas, pode ter tido origem remota em recompensas obtidas ao longo de suas vidas.

A partir da Teoria das Necessidades Aprendidas, pode-se concluir que o meio interfere no comportamento das pessoas e também em atividades de trabalho e seria importante identificar o perfil desejado de um cargo, para depois determinar quais características individuais estariam ligadas a ele.

Ao terminar este tópico, pode-se considerar que os autores aqui elucidados representam base conceitual de muitos estudos sobre Qualidade de Vida no Trabalho, pois ao pesquisarem o comportamento das pessoas, estes autores trouxeram contribuições importantes, tais como: o "fator psicológico", que Mayo identificou; a hierarquia das necessidades de Maslow, que subsidiou muitos estudos posteriores; a Teoria $\mathrm{X}$ e $\mathrm{Y}$ de McGregor que deu início às modificações comportamentais dos administradores frente aos trabalhadores; o enriquecimento do cargo proposto por Herzberg e por último, a inclusão da importância do meio e da cultura sobre as necessidades aprendidas de McClelland. 


\subsection{Conceitos de Qualidade de Vida no Trabalho}

A primeira metade do século $X X$ apresentou dois movimentos distintos: de um lado, a concepção voltada à produtividade e de outro, a preocupação com a satisfação com o trabalhador.

Os estudos sobre Qualidade de Vida no Trabalho, segundo Rodrigues (1994, p.76) e Fernandes (1996, p.40), é atribuído a Eric Trist e seus colaboradores que, em 1950, desenvolveram diversas pesquisas no Tavistock Institute de Londres, dando origem a uma abordagem sóciotécnica em relação à organização do trabalho, ao apresentarem experiências centradas na relação existente entre os indivíduos, o trabalho e a organização, com base na análise e reestruturação da tarefa e como objetivo de tornar a vida dos trabalhadores menos penosa.

Na década de 60 do século passado, as pesquisas sobre QVT apresentaram um grande avanço, segundo a literatura, impulsionadas pela crescente conscientização dos trabalhadores acerca de suas condições de trabalho, bem como pela responsabilidade social atribuída às empresas, despertando o interesse por estudos voltados para melhorar as formas de trabalho.

\footnotetext{
Este período estendeu-se até a década de 70 e caracterizou-se por uma sociedade com perspectivas progressistas e preocupada com a saúde, segurança e satisfação dos trabalhadores.
} 
Chiavenato (2000) refere que o termo Qualidade de Vida no Trabalho (QVT) foi cunhado por Louis Davis na década de 70, quando desenvolvia um projeto sobre o desenho de cargos", explicitando que o termo refletia a preocupação com o bem-estar geral e a saúde dos indivíduos no desempenho de suas tarefas (p.390 -1).

Segundo Rodrigues (1994), o início da década de 1970 foi marcado pela conhecida "crise do petróleo" e pelas altas taxas de inflação que atingiram muitos países ocidentais, entre eles os Estados Unidos, levando também a uma desaceleração nos rumos da QVT (p.78).

Afirma também Rodrigues (1994) que a preocupação com a qualidade de vida no trabalho voltou a merecer atenção em 1979 e início da década de 80, quando o Japão tornou-se alvo de estudos devido à adoção de técnicas administrativas voltadas para a qualidade, principalmente os "Ciclos de Controle de Qualidade" -CCQ- que visavam o alcance da Qualidade Total - QT (p.78).

Os anos 90 foram influenciados pela difusão dos conhecimentos sobre QVT, sendo que países como a França, Alemanha, Dinamarca, Suécia, Noruega, Holanda e Itália adotaram modelos e métodos de trabalho, com vistas à satisfação de seus clientes internos e externos. $\mathrm{Na}$ Inglaterra, Checoslováquia, Hungria, lugoslávia, Canadá, México e Índia a abordagem da QVT apresenta um desenvolvimento significativo. No Brasil, alguns estudos começaram a surgir nos Estados do RS, RN, SP, SC, MG e CE, dando margem a uma perspectiva de difusão ainda maior. 
No que se refere à expressão QVT, esta é frequentemente aplicada nas organizações para justificar uma diversidade de mudanças que nem sempre visam o bem-estar do trabalhador escamoteando a verdadeira intenção de aumentar a produtividade com menos recursos.

Neste aspecto, Limongi-França e Rodrigues (1999), ao analisarem a situação brasileira, afirmam que "a realidade gerencial no Brasil tem mostrado que, na prática, Qualidade de Vida no Trabalho tem sido compreendida de forma parcial e incompleta. A atuação da qualidade voltada para pessoas frequentemente traz um referencial assistencialista, algumas vezes benemérito, ou, simplesmente, ações gerenciais que ignoram a qualidade de vida no trabalho nas políticas de recursos humanos e nos processos das empresas ou na reparação de aspectos humanos e ambientais que neutralizam riscos na condição de trabalho" (p.137).

Esta situação, talvez esteja associada à dificuldade de conceituação manifestada pelos autores, devido ser uma expressão abrangente e carregada de subjetividade.

Walton (1973) apresenta esta característica abrangente e subjetiva em seu conceito, dizendo que qualidade de vida no trabalho visa proteger o empregado e propiciar-Ihe melhores condições de vida dentro e fora da organização. Segundo este autor, para que a qualidade de vida no trabalho seja alcançada, é necessário que o trabalhador tenha: remuneração adequada e justa, condições de segurança e saúde no trabalho, oportunidade imediata para utilização e desenvolvimento da capacidade 
humana, oportunidade para crescimento contínuo e segurança, integração social na organização, constitucionalismo na organização do trabalho, trabalho e o espaço total da vida, a relevância social da vida no trabalho.

Davis e Werther (1983), da mesma forma, referem que a QVT é "afetada por muitos fatores: supervisão, condições de trabalho, pagamento, benefícios e projetos do cargo. Porém, é a natureza do cargo que envolve mais intimamente o trabalhador" (p.71).

Quirino e Xavier (1987) reforçam a importância do grau de satisfação das necessidades pessoais, através de suas realizações nas empresas, para o alcance da QVT.

Vieira e Hanashiro (1990), referem-se à qualidade de vida no trabalho (QVT) como as condições favoráveis ou desfavoráveis ao empregado, resultantes do ambiente de trabalho. Estas autoras conceituam a QVT como sendo: "Aplicação concreta de uma filosofia humanista, pela introdução de métodos participativos, visando modificar aspectos do local de trabalho, a fim de criar uma situação nova, mais favorável à satisfação dos empregados."

Chiavenato (2000) define QVT, afirmando que "representa o grau em que os membros da organização são capazes de satisfazer as necessidades pessoais através de experiências na organização. A qualidade de vida no trabalho afeta atitudes pessoais e comportamentos importantes para a produtividade individual, tais como: motivação para o trabalho, 
adaptabilidade a mudanças no ambiente de trabalho, criatividade e vontade de inovar ou aceitar mudanças" (p.238).

Fernandes (1996) apresenta um aspecto mais abrangente em seu conceito, ao afirmar que QVT é "a gestão dinâmica e contingencial de fatores físicos, tecnológicos e sócio-psicológicos que afetam a cultura e renovam o clima organizacional, refletindo-se no bem estar do trabalhador e na produtividade das empresas" (p.45-6).

Matos (1999), argumenta que as abordagens de QVT, na maioria das vezes, enfatizam dois aspectos antagônicos. O primeiro se refere às reivindicações dos trabalhadores, com prioridade ao aspecto de bem-estar e satisfação no trabalho enquanto meta que termina em si mesma. O segundo, com ênfase nos efeitos da QVT sobre a produção e produtividade, em defesa dos interesses da empresa que atendem aos interesses do capital. E ainda, que outras abordagens associam qualidade de vida no trabalho a aspectos mais amplos como: condição de cidadania, de participação e democratização nos ambientes de trabalho.

Limongi-frança (2001) na tentativa de expressar uma síntese que envolvem os estudos sobre QVT, diz que, " na verdade, a base da discussão sobre o conceito de qualidade de vida encerra escolhas de bemestar e percepção do que se pode ser feito para atender expectativas criadas tanto por gestores, como por usuários das ações de QVT nas empresas" (p.11). 
A partir dos estudos até então divulgados, Nadler e Lawler (1983) apontam a evolução pela qual passou o conceito de QVT ao longo do tempo, sintetizando essa mudanças por meio do seguinte quadro:

Quadro 2: $\quad$ Definições Evolutivas da QVT

\begin{tabular}{|c|c|l|}
\hline PERÍODO & $\begin{array}{c}\text { FOCO } \\
\text { PRINCIPAL }\end{array}$ & \multicolumn{1}{c|}{ DEFINIÇÃo } \\
\hline $1959 / 1972$ & Variável & $\begin{array}{l}\text { A QVT foi tratada como reação individual ao trabalho ou às } \\
\text { consequências pessoais de experiências do trabalho. }\end{array}$ \\
\hline $1969 / 1975$ & Abordagem & $\begin{array}{l}\text { A QVT dava ênfase ao indivíduo antes de dar ênfase aos } \\
\text { resultados organizacionais, mas ao mesmo tempo era vista } \\
\text { como um elo dos projetos cooperativos do trabalho } \\
\text { gerencial. }\end{array}$ \\
\hline $1972 / 1975$ & Método & $\begin{array}{l}\text { A QVT foi o meio para o engrandecimento do ambiente e a } \\
\text { execução de maior produtividade e satisfação. }\end{array}$ \\
\hline $1975 / 1980$ & Movimento & $\begin{array}{l}\text { A QVT, como movimento, visa a utilização dos Termos } \\
\text { "gerenciamento participativo" e "democracia industrial" com } \\
\text { bastante frequência, inovador como ideais do movimento. }\end{array}$ \\
\hline Previsão Futura & Tudo & $\begin{array}{l}\text { A QVT é vista como um conceito global e como uma forma } \\
\text { de enfrentar os problemas de qualidade e produtividade. }\end{array}$ \\
\hline
\end{tabular}

Fonte: Nadler e Lawler, 1983. in Rodrigues (1994, p.81)

Pesquisas produzidas no Brasil no final do século passado, apontam que após esta sinópse de Nadler e Lawler a QVT teve uma importante fase cujo início se deu por volta dos anos 70, quando esforços ressurgem no sentido de resgatar o trabalho enobrecedor e significativo, como canal para a realização pessoal, crescimento profissional, alcance de recompensas intrínsecas e extrínsecas, e desenvolvimento de novas habilidades e ampliação do potencial.(Rodrigues,1994) 


\subsection{A Visão Contemporânea da QVT}

Vivemos em um mundo em constante transformação, no qual os acontecimentos nos trazem a única certeza de que as mudanças são constantes nesse novo paradigma social, organizacional e institucional. As pessoas, por sua vez, diante dessa realidade, acumulam atividades profissionais, assumem compromissos de capacitação pessoal, cuidam da família, enfim, desdobram-se para atender às múltiplas e concorrentes exigências da competitividade no trabalho e na vida na pós-modernidade .

A pós-modernidade trouxe novos comportamentos, mudanças de perfis profissionais, nos hábitos das pessoas e nos valores. 0 cidadão se vê cada vez mais sobrecarregado de trabalho, de informações, desgastando-se em jornadas diárias repletas de eventos e de afazeres, isto quando este não é excluído do mercado de trabalho por não ter um perfil de competências que seja valorizado.

Para tanto, as pesquisas que enfocam o comportamento humano no contexto das organizações produtivas, requerem uma abordagem integrada, multifacetada e interdisciplinar, em função da complexidade e transitoriedade que as mudanças impõem ao cotidiano da vida.

Neste sentido, pode-se observar que as contribuições ao estudo do desenvolvimento social e humano, bem como da condição humana no trabalho vêm de diversas ciências, tais como a Psicologia, a 
Antropologia, a Sociologia e a Economia. Esta última apresenta, entre outros, a importância de associar-se aos estudos de qualidade de vida no trabalho o Índice de Desenvolvimento Humano (IDH), o Índice de Desenvolvimento Social (IDS) e o Índice de Condições de Vida (ICV).

Um informe da Organização Internacional do Trabalho - OIT (2000), apresenta um estudo acerca das políticas e programas de saúde mental relacionadas aos trabalhadores da Alemanha, Estados Unidos, Finlândia, Polônia e Reino Unido, mostrando que a incidência dos problemas de saúde mental entre os trabalhadores está aumentando, sendo que um em cada dez trabalhadores sofre de depressão, ansiedade, estresse ou cansaço, que em alguns casos levam ao desemprego e à hospitalização. (Carandina, 2003)

Além dos aspectos oriundos da determinação da economia globalizada, a QVT é enriquecida por estudos que abordam riscos ocupacionais, ergonomia, saúde e segurança do trabalho, carga mental, esforços repetitivos, comunicação tecnológica, psicologia do trabalho, processos comportamentais que definem a inteligência emocional, expectativas no trabalho, motivação, liderança, fidelidade `a empresa, empregabilidade, entre outros que visam o estudar os multifacetados aspectos da relação indivíduo/trabalho.

Moreira (2001) comenta que, no mundo das idéias, hoje, está disseminado o pacto com a chamada "qualidade de vida" em todas as áreas do saber. Ressalta que visando a busca da qualidade de vida, parte- 
se do princípio de que, alterando-se as estratégias daquilo que é feito, ou alterando - se alguns critérios que balizam ações no dia-a-dia, será possível reverter o quadro de desqualificação da vida atual. Entretanto, nas práticas profissionais esses fatores encobrem muito da exploração do indivíduo no trabalho.

Neste sentido, Moreira (2001) relata que essas propostas são portadoras do idealismos positivista que tem marcado os estudos da relação saúde trabalho, que escamoteiam os reais nexos causais dos processos determinantes da qualidade de vida no trabalho. .

Tendo em vista que a QVT tem sido objeto de estudos em diversas áreas, faz-se necessário o resgatar o conhecimento produzido em estudos na área da saúde e, especificamente, os da área de Enfermagem, relacionados a esse objeto.

\subsection{A Qualidade de Vida no Trabalho da Enfermagem}

No Brasil, a preocupação com a QVT dos profissionais da área da saúde é ainda pouco abordada, tanto nas instituições de saúde da rede pública, quanto da particular.

Destacam-se alguns estudos brasileiros que adotam a temática QVT sob enfoques distintos: 
Silva e Massarollo (1998) abordam a QVT de enfermagem sob o enfoque da determinação social, com recorte teórico voltado para a qualidade de vida relacionada à saúde dos trabalhadores de enfermagem. Sob este foco, referem as autoras que "a qualidade de vida é determinada pelas contradições existentes entre os aspectos saudáveis que o grupo desfruta e aspectos destrutivos de que padece, tanto no momento produtivo - na situação de trabalho, como no momento de consumo - na vida social. Considerando o momento produtivo na determinação da qualidade de vida dos trabalhadores de enfermagem, um perfil favorável é confrontado com um perfil destrutivo. Esse perfil destrutivo se expressa pelos processos de desgaste que comprometem a potencialidade de saúde e de vida dos trabalhadores de enfermagem."

Em consonância com o referencial materialista histórico dialético utilizado pelas autoras, os membros de cada classe social, de acordo com o seu modo de inserção no processo produtivo e seus padrões, característicos de consumo e da sua forma de organização e cultura, se desenvolvem em contradições. De um lado, coexistem as forças benéficas que protegem a saúde e de outro, os aspectos destrutivos que contribuem para a sua deterioração. Sendo assim, nesse referencial, é no sistema de contradições no momento da reprodução social que se define a qualidade de vida.

Desta forma, as autoras afirmam que os trabalhadores de enfermagem vivem as contradições: experimentando de um lado, aspectos 
potencializadores da saúde e de outro, em oposição, os aspectos destrutivos, gerados no momento de produção de seu trabalho.

$$
\text { Shimizu (2000) revela em seu estudo sobre as }
$$
representações das enfermeiras de UTI, que as atividades por elas desenvolvidas são prazerosas, mas, que o desgaste e o sofrimento também estão presentes no cotidiano de trabalho, sobretudo o desgaste emocional que tem sua origem: no ritmo de trabalho intenso, na necessidade de conviver com o sofrimento e morte e de executar atividades que exigem um alto nível de responsabilidade, entre outros fatores.

Peña e Shirley (2000), analisam a gestão de QVT em um hospital psiquiátrico público e observam uma deficiência em várias facetas das dinâmicas sociais no ambiente de trabalho, como: a dificuldade de criação de espaços participativos, a falta de liberdade e criatividade no serviço, aprender a pensar e a crescer em harmonia, dificuldade para as mudanças e vários outros aspectos de indicadores ausentes de qualidade de vida no trabalho como: educação e aprendizagem, lazer no trabalho, crescimento e transformação interior e ausência de burocracia. Concluem que as características de QVT são de valorização do discurso e, muito comprometido no cotidiano por questões culturais, normativas, burocráticas e institucionais

Haddad (2002), realizando uma revisão da literatura, verifica não haver uma definição consensual a respeito de QVT, mas sim várias correntes ou abordagens. No entanto, acredita estar a temática associada à 
melhoria das condições físicas do servidor, programa de lazer, estilo de vida, instalações organizacionais adequadas, atendimento a reivindicações dos trabalhadores e ampliações do conjunto de benefícios. Descreve que a dinâmica do trabalho de enfermagem não leva em consideração os problemas do trabalhador, que cada indivíduo enfrenta no cotidiano dificuldades de toda ordem, fora e dentro do trabalho, mas esperando-se do profissional que ele jamais expresse junto ao paciente seus dissabores, ao contrário, espera-se dele serenidade. Argumenta que o modelo de "mãe cuidadora e abnegada" é introjetado pela enfermagem enquanto coletividade de trabalhadores. Provavelmente, isso explique, por que as enfermeiras toleram alto grau de sofrimento no trabalho e sejam pouco articuladas para fazer reivindicações de melhorias na QVT.

Partindo destes aspectos, a autora propõe a implantação de um Programa Interdisciplinar de Apoio ao Trabalhador de Enfermagem que promova e mantenha a QVT.

Leitão (2002) identificou e analisou as representações sociais de enfermeiras, no cotidiano do trabalho gerencial, numa instituição hospitalar que implementa Programa de Qualidade e buscou compreender as razões e as motivações pelas quais as enfermeiras entendem 0 programa, e qual o impacto tanto individual quanto coletivo sobre o trabalhador de enfermagem. O ambiente de trabalho é identificado como controlador, caracterizado pelo excesso de cobranças, o que sinaliza para limitação da liberdade e, consequentemente, menor espaço para 
criatividade, gerando sentimentos negativos, como tristeza, decepção e angústia. A organização sistêmica do trabalho provoca excesso de trabalho para as enfermeiras, resultando em desgaste físico e psíquico que podem levar ao sofrimento mental. As conquistas são definidas como geradoras de sentimentos positivos, como satisfação e orgulho pelo reconhecimento do trabalho realizado e valorização profissional que reforçam a auto-estima. Partindo destes resultados, a autora propõe uma maior participação das enfermeiras nas discussões de assuntos que tratem de problemas individuais e coletivos, que venham melhorar a qualidade de vida no trabalho das enfermeiras. Neste fórum de debate poderão ser desenvolvidos mecanismos coletivos defensivos, descritos pela nova Pscicopatologia do Trabalho, ampliando a base de forças dos funcionários para a transformação de situações inadequadas do ambiente de trabalho, em busca do sentido e da dignidade do trabalho.

Rocha (2002), em pesquisa qualitativa, analisando a QVT de 15 enfermeiros docentes de uma Universidade Privada do Estado de São Paulo, encontrou nove subcategorias par a categoria QVT docente de Enfermagem, a saber: condições de trabalho, remuneração, relacionamento interpessoal, identificação profissional, reconhecimento profissional, autoestima, tempo, estrutura administrativa e auto desenvolvimento. Utilizando o referencial da determinação social, a autora conclui que as condições potencializadoras para a QVT docente de Enfermagem são: investimento na capacidade docente, o perfil da instituição, o relacionamento profissional, o relacionamento com os discentes, as características do ensino, a 
identificação profissional, a organização do conteúdo, a competitividade institucional e a relação com o ensino prático. Enquanto as condições desgastantes da QVT docente de Enfermagem são: o regime de trabalho, a relação da teoria com a prática, as interferências na vida familiar, a remuneração, os aspectos didático - pedagógicos, a estrutura administrativa, a identificação profissional e o relacionamento interpessoal.

Souza (2003) abordou a QVT dos profissionais da equipe de enfermagem de uma Unidade de Terapia Intensiva Pediátrica e Neonatal (UTIP/N) como um dos aspectos fundamentais na proposta do gerenciamento participativo. O grupo, a partir das discussões, formulou estratégias para enfrentar as situações, considerando a governabilidade individual e institucional, como aprender a trabalhar com as diferenças, estreitar as relações interpessoais com a chefia e criar oportunidades para desenvolver atividades com os familiares. A discussão em grupo foi percebida como uma atividade reflexiva, transformadora, que permitiu conhecer o outro e compreender suas limitações e possibilidades.

Carandina (2003), em seu estudo, construiu e validou um instrumento de medida de QVT para enfermeiras. Quanto ao significado de QVT, este foi associado à percepção de satisfação e de bem-estar em relação a diferentes aspectos presentes em seu trabalho. Em relação aos seus indicadores, a autora descreve como os mais importantes: " 0 relacionamento interpessoal vertical e horizontal; o reconhecimento profissional, a preocupação com a qualidade do trabalho desenvolvido; a 
autonomia e estabilidade de emprego; a operacionalização do trabalho diário; as condições ergonômicas; a remuneração e recompensa; o tempo destinado ao trabalho e as oportunidades de crescimento profissional; a profissão e aspectos relacionados com o pessoal e o material disponível para trabalhar".

Schmidt (2004) ao avaliar e correlacionar as variáveis qualidade de vida e qualidade de vida no trabalho de profissionais de enfermagem atuantes em unidades do Bloco Cirúrgico de quatro hospitais da cidade de Londrina - PR, constatou que a Remuneração foi considerada como fonte de menor satisfação entre os trabalhadores, enquanto o domínio "Status" profissional, o de maior satisfação e que não há correlação entre as QV e QVT.

Carvalho (2004) aborda o trabalho de enfermagem psiquiátrica e os problemas de saúde dos trabalhadores sob o referencial do materialismo histórico-dialético. Verifica que, pela exposição, o desgaste apresenta-se tanto físico como mental. Este é atribuído às condições de trabalho vivenciadas e não pelo objeto de trabalho. As estratégias de enfrentamento empregadas pelos trabalhadores são: a satisfação no trabalho, o suporte social dos colegas de trabalho, a participação no grupo focal e o lazer.

Lino (2004) ao estudar 190 enfermeiras de unidades de terapia intensiva, constatou que são valorizados os seguintes aspectos: autonomia, interação e remuneração mais do que "status" profissional, 
requisitos do trabalho e normas organizacionais. Encontrou correlações significativas entre os domínios da qualidade de vida e os componentes da satisfação profissional. Quanto à análise das percepções e estados de vida e trabalho, os resultados sugerem que eles são indicadores potenciais de qualidade de vida e satisfação profissional. A autora confirma as relações entre os domínios da vida no trabalho e da vida fora do trabalho das enfermeiras, e demonstra o significado das características do trabalho em UTI na discussão da qualidade de vida das enfermeiras.

Como se pode observar por estes estudos, também na área de enfermagem a QVT tem sido abordada de várias formas. Somando-se aos aspectos inerentes às condições de trabalho na área da enfermagem, já bem explorados nos estudos específicos, pode-se enumerar outros fatores da dimensão estrutural que agudizam os problemas nessa esfera do trabalho em saúde e na enfermagem.

Desde a década de 80, estudiosos apontam para uma redução do emprego formal e o aumento do emprego informal, caracterizando um processo de maior complexificação da classe trabalhadora.

A tendência atual descrita por Antunes (2001), portanto, é: uma diminuição do proletariado nas indústrias; aumento do setor de serviços; aumento do trabalho feminino; aumento do trabalho temporário, terceirizado; aumento do desemprego estrutural, com conseqüente exclusão dos mais jovens e dos mais velhos. 
Em decorrência disto, o grupo de trabalhadores de enfermagem ficam, também, submetidos a demandas específicas nos processos saúde-doença, também em função da perda de direitos trabalhistas (licenças, férias remuneradas, etc). Esta situação pode significar uma intensificação do ritmo de trabalho, potencializando aspectos destrutivos, como por exemplo, acidentes de trabalho e outros processos de desgaste que merecem ser melhor investigados.

\subsection{Qualidade de Vida em estudantes universitários}

Os estudos mais gerais sobre QV na população são muito importantes para o desenvolvimento contínuo de indicadores sociais, para o desenvolvimento de padrões normativos de comparação e como componente focal de esforços para promoção da educação/formação de recursos humanos em diferentes setores.

Ao buscarmos referências de estudos que abordam QV do aluno universitário é interessante citar o trabalho desenvolvido por Pascarella e Terenzini (1991), sobre a repercussão da educação superior na qualidade de vida da população diplomada em cursos superiores. O estudo, além de apresentar extensa revisão bibliográfica, os autores salientam a melhoria da QV daqueles que ascendem a cursos superiores citando: as tomadas de decisões sobre a própria vida econômica, emocional, no trabalho e no cuidado com própria saúde, assim como o fato de o indivíduo tornar-se mais crítico e exigente. 
Os autores relacionam a QVE com o bem-estar subjetivo, a satisfação é descrita como um estado emocional aprazível. Trata-se do resultado da representação do papel de ser um estudante. Comentam que os estudantes alcançaram graus bons porque eles estavam satisfeitos, e não satisfeitos porque eles receberam graus bons.

Para Demo (1996), "qualidade de vida" representa o desafio de fazer história humana com o objetivo de humanizar a realidade e a convivência social. Oportunizar fazer uma história que vale a pena ser vivida, depende das circunstâncias dadas e da capacidade de construir e participar da sociedade. Menciona a cidadania, considera qualidade de vida como a humanização da realidade e da vida. Inclui desde a habitabilidade até a relação humana no sentido de participação, democracia, equidade, consumo, enfim a cidadania.

A qualidade de vida dos estudantes universitários é uma preocupação que vem sendo focada desde a década de 80. Benjamin (1994), um dos estudiosos do tema, realizou uma revisão desses trabalhos, tendo como um dos objetivos a elaboração de uma definição clara do conceito. Para isso, utiliza-se de uma classificação dos trabalhos publicados nos domínios de estudo (social, institucional e estudante) relacionando o tipo de abordagem utilizada nessas investigações.

Segundo Benjamin, as análises das publicações sugerem que a Qualidade de Vida dos Estudantes (QVE) possa ser entendida como "a percepção de satisfação e felicidade, por parte do estudante em relação a 
múltiplos domínios de vida à luz de fatores psicossociais e contextuais relevantes e estruturas de significados pessoais".

Os domínios de vida reconhecidos, segundo Benjamin (1994), são: 1) social; 2) individual; 3) acadêmico 4) gênero; 5) finanças; 6) moradia; 7) serviços da universidade; 8) administração universitária e 9) outros (entre estes, saúde).

As circunstâncias objetivas, relatadas pelo autor em sua definição, incluíram uma faixa de indicadores demográficos, como: idade, gênero, classe social, etnia, assim como indicadores de saúde física no momento presente. Da mesma forma, circunstâncias institucionais incluíram indicadores, tais como ano acadêmico, currículo, número de cursos etc. Entre os fatores psicossociais, distinguem-se os eventos situacionais (estresse) e estados emocionais prevalecentes (depressão, ansiedade).

Em relação às circunstâncias objetivas e os fatores psicossociais, Mendes (2002) revela em seu estudo que os estudantes de enfermagem do primeiro ano referiram a existência de momentos de maior estresse durante o curso. Destacaram-se os referentes às avaliações e os períodos de ensino prático. Ao estudar a influência do stress na saúde dos alunos, relacionou as alterações imunológicas encontradas neste período. $\mathrm{Na}$ análise das diferenças individuais destas respostas, encontrou um elevado coeficiente de determinação nos seguintes fatores: autoresponsabilização e medo das consequências e pedido de ajuda, entendido 
na perspectiva da valoração da existência, ou não, de uma rede social de apoio.

Ao estudar a variável peso, a autora constatou houve mudança no peso dos estudantes sendo que o aumento mostrou estar significativamente relacionada a estilos de "coping" centrado nas emoções de abandono passivo perante as situações de agressividade internalizadas/externalizadas. Quanto à resultante saúde, verificou a existência de um número significativo de alunos que expressavam uma sintomatologia depressiva leve e uma percepção globalmente mais negativa das suas condições de saúde no período dos exames.

Finalmente, Benjamin (1994) estudando a qualidade de vida de estudantes universitários de diferentes áreas, cita as estruturas de significados pessoais que incluiam: padrões de interação familiar prevalecente, expectativas e objetivos do estudante e identidade do estudante, especialmente auto-estima e auto-percepção de competência. Segundo o autor, essa formulação complexa só será inteligível ao ser colocada em prática nos cenários de outras investigações.

Esse domínio de adequação da relação entre aluno e universidade foi estudado por Nico (2000) ao formular o conceito de conforto acadêmico o que justifica e será o ponto decisivo para a permanência ou não do aluno na instituição de ensino.

A revisão feita por Benjamin aponta a QVE como fator relevante ao estar relacionado a resultados importantes do desempenho do

\footnotetext{
${ }^{2}$ Refere-se aos esforços para lidar com situações de dano, ameaça ou de desafio quando não está disponível uma rotina ou uma resposta automática.
} 
estudante, como performance acadêmica, tempo para a graduação, satisfação do estudante com o curso, persistência institucional, conduta em classe, relações sociais, envolvimento extra-curricular, interação paisestudante, e conflitos com colegas de república. Segundo o autor, o papel desempenhado pela QV sobre a vida do estudante de graduação justifica sua inclusão como uma importante variável nos esforços de compreensão das experiências e resultados atribuídos pelos estudantes ao processo vivido em sua formação.

Benjamin (1994), em revisão e discussão da literatura relacionada ao tema qualidade de vida de estudantes universitários, considera os modelos existentes para análise úteis, porém, incompletos. Propõe então, um modelo substituto, construído a partir dos pontos fortes dos modelos revisados. Este modelo é por ele denominado de "Modelo Ecológico de QVE”. Esse é fundamentado nos seguintes conceitos: o primeiro, diz respeito à relação do indivíduo com o seu contexto (social, histórico e físico). O segundo, abrange a compreensão do comportamento dos indivíduos que é sempre apreendida a partir de algum contexto específico, dentro do qual aconteceu. Finalmente, o terceiro conceito fundamenta-se na premissa de que a realidade dos indivíduos é construída socialmente, ou seja, o comportamento necessariamente surge de algum sistema de significado que, por sua vez, é criado, mantido e modificado através da interação social. Desse modo apreende-se que a vida consiste 
em relação social que permite ou não o crescimento, enquanto integra, coopera, compartilha, e compete com outros.

De acordo com Benjamin (1994), seguramente, a maioria de nós teve as experiências significativas dentro de alguma forma da agrupamento social complexo, muitas vezes representado pela família.

Com base nesses pressupostos, o modelo é descrito na Figura 1.

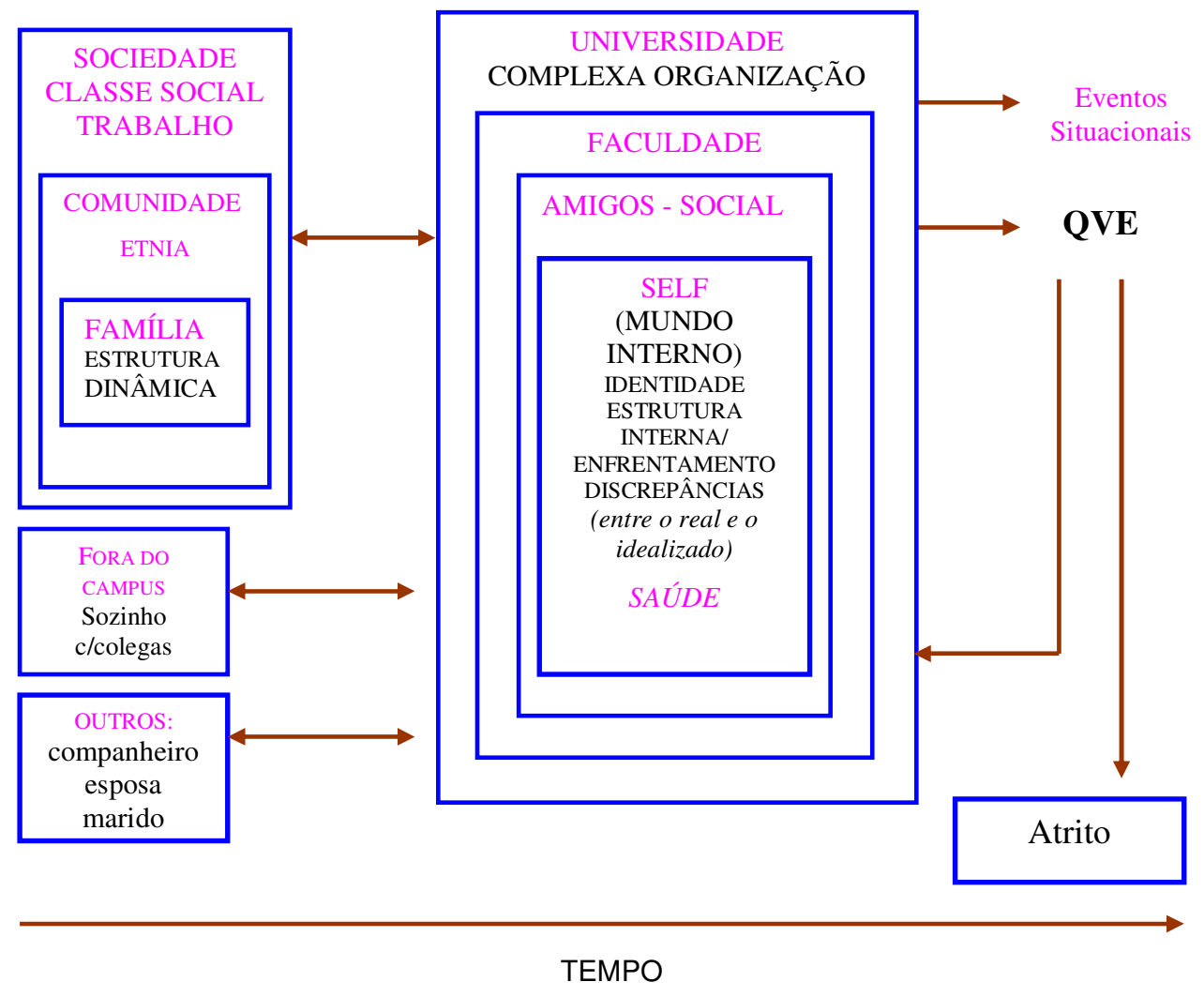

Figura 1: $\quad$ Modelo Ecológico de QVE proposto por Benjamin (1994) 
A família é descrita pelo autor como ponto fundamental na interação com a estrutura demográfica da vida do estudante e como um lugar particular no ciclo de vida. Destaca, ainda, a comunidade étnica particular onde o indivíduo se insere, o local geográfico onde vive e a sociedade. Para o autor há uma mútua influenciação entre o indivíduo, família e sociedade, na apreensão da qualidade de vida do estudante. Considera também as influências sociais diferentes da familiar, e especificas de cada curso e das situações de moradia dos estudantes (em residência no campus ou fora-campus, se diariamente viaja para a universidade ou não).

A universidade é descrita de forma semelhante, isto é, também interagindo com uma série de contextos: do indivíduo singular ou do "self " do estudante em termos de identidade (acadêmica; confiança social; amor-próprio; gênero, e estado afetivo). No âmbito da estrutura, propiciando que atinja expectativas, metas e valores, ou, que haja discrepâncias entre as aspirações e a realidade, entre os padrões de pensamento e de ação, e por fim condições de saúde física e mental.

A Universidade como contexto social, propicia também espaços de relacionamentos com amigos e colegas, para os que vivem ou não no campus. A Universidade como academia, é também espaço de relações como curso profissionalizante, favorecendo a escolha de programas, e experiências de trabalhos na academia (experiências de disciplinas eletivas e optativas dentro ou fora de sala de aula); e, a Universidade como organização complexa que compreende uma dada 
estrutura hierárquica, complexidade administrativa, formas de avaliação, tipos atividades curriculares e extracurriculares, nas quais o estudante participa).

Argumenta que esse contexto pode afetar o estudante, positiva ou negativamente, por uma gama de possíveis eventos e situações vividas, perpassando relações de poder e autonomia.

A interação destes vários contextos, familiar e universitário, determinam a QVE. Concebe como variável independente a estrutura familiar e a universidade com sua estrutura típica, como variável dependente.

A QVE positiva aumentará a probabilidade do sucesso acadêmico e social, considerando que uma QVE negativa diminuirá esta probabilidade, inclusive a possibilidade de contestação ou de resiliência.

Finalmente, QVE é vista como uma variável dependente do tempo. Isso significa que o tempo que o estudante passa em uma determinada instituição dará peso ou significado diferente para os fatores que irão sugerir a operação de domínios adicionais para diferentes grupos de estudantes.

Por exemplo, ajuste no período de transição/adaptação é pertinente para a QVE de estudantes recém admitidos, enquanto que oportunidades de emprego afetam mais significativamente a QVE de alunos que estão se formando. 
De forma mais geral, este modelo aponta variáveis relevantes e indica sua localização (dentro ou fora do campus). Mostra até que ponto as avaliações do estudante sobre a sua qualidade de vida acontecem simultaneamente numa variedade de contextos.

Benjamin (1994) comenta que esta representação gráfica do modelo está limitada, primeiro, por ser um modelo bidimensional, pois, realmente deveria envolver uma sucessão animada tridimensional que se move com o tempo. Segundo, esta limitada pela omissão deliberada de uma descrição detalhada de como as variáveis específicas interagem. Uma observação comum são aquelas relações com familiares, relações românticas, relações com membros do corpo docente e outros - como uma fonte primária de conflitos. Estas relações são vistas, como fortemente associadas com a QVE. Logo, a vida e os eventos, particularmente eventos negativos, são fontes primárias de tensão.

Concordamos com o autor, que este modelo de análise da QVE deveria ser apresentado de forma tridimensional, pois as relações ocorrem de forma integrada e dinâmica. Em relação às variáveis específicas, como as exemplificadas pelo autor, estas serão contempladas a partir da proposta de adaptação do modelo para a QVE.Enf., que a ser discutida no capítulo 6.

Esses estudos mostram que na última década do milênio passado, a preocupação com a qualidade de vida de estudantes em processo de formação profissional vêm ganhando espaço enquanto objeto 
de pesquisa, sendo uma das preocupações a de correlacionar as condições de vida do estudante com a evasão dos cursos e satisfação na profissão.

Muitas Universidades vêm desenvolvendo programas de avaliação da integração à vida acadêmica (Almeida, 1998), docentes pesquisando as condições relacionadas ao aprendizado (Santos, 2001), condições espaciais, materiais, temporais e pessoais para o estudo (Mercuri, 1992), evasão de clientela (Polydoro, 2001), a satisfação do aluno com a instituição (Nico, 2000), qualidade de vida do estudante (Oliveira, 1999; Souza e Guimarães, 1999, Saupe et al, 2002, Kawakame e Miyadahira, 2005), e qualidade de vida de alunos trabalhadores ( Iglesias, 2002).

Como já referia Benjamin (1994) em sua revisão bibliográfica e acrescidos os estudos acima mencionados, é possível afirmar que se justifica outros estudos relacionados ao mesmo objeto, tendo em vista as necessidades crescentes de se dar melhores respostas ao processo ensinoaprendizado e ao desenvolvimento de competências nos alunos.

Esses estudos é que propiciarão as bases para realizar intervenções visando a melhoria do ensino e a adequada formação dos alunos, através de um conhecimento mais aprofundado e particular de cada população e contextos específicos.

Atualmente, essa preocupação tem sido assumida de forma mais sistemática e com maior interesse e várias teorias e modelos pedagógicos surgiram para o estudo das mudanças pelas quais passa 0 ensino universitário. 
Segundo Pascarella \& Terenzini, (1991) esses estudos podem ser classificados como: 1) desenvolvimentistas, que se preocupam com a natureza, estrutura e processos de crescimento individual e 2) os modelos de impacto cuja preocupação é estudar a origem ambiental ou social da mudança do aluno.

A transição entre a vida de estudante e profissional assume formas e problemas específicos em cada contexto, consoante às exigências colocadas pelas características de desenvolvimento dos próprios estudantes e dos cursos. Esta transição implica uma necessidade de ajuste social e emocional ou a aquisição das estratégias de "coping”, necessárias para fazer face aos novos papéis, entre outras exigências (Santos, 2001).

\subsubsection{Qualidade de Vida em estudantes de Enfermagem.}

No que se refere especificamente QVEEnf., encontramos nos bancos de dados poucos estudos que utilizam como palavras chave Qualidade de vida do estudante. Entretanto, nos chama a atenção uma certa quantidade de trabalhos/estudos cujo objeto esteja relacionado ao processo ensino - aprendizagem dos alunos de enfermagem.

Em estudo de revisão bibliográfica, realizado na sub-base de dados on-line BDENF (Base de dados em enfermagem), específica da área de enfermagem, dentro da biblioteca virtual em saúde MEDLINE (Medical Literature Analysis na Retrietal Systen on-line), encontramos 21 publicações 
nos últimos 7 anos. Estes estudos sobre ensino-aprendizagem foram selecionados, pois, em sua temática, envolvem as circunstâncias objetivas, relatadas por Benjamim em sua definição que inclui além de outros indicadores, os da saúde física no momento presente e, como circunstâncias institucionais, incluíram indicadores, tais como ano acadêmico, currículo, número de cursos etc. Entre os fatores psicossociais, distinguem-se os eventos situacionais (estresse) e estados emocionais prevalecentes (depressão e ansiedade).

Quadro 3: $\quad$ Qualidade de vida de estudantes de enfermagem - revisão bibliográfica nos periódicos do Brasil relacionados com QVE.Enf., 1999 - 2005.

\begin{tabular}{|c|c|c|c|c|c|c|}
\hline ZANO & AUTOR & TITULO & OBJETIVOS & METODOLOGIA & NIVEL & LOCAL \\
\hline 2005 & $\begin{array}{l}\text { Kawakame, } \\
\text { PMG; } \\
\text { Miyadahira, } \\
\text { AMK }\end{array}$ & $\begin{array}{l}\text { Qualidade de Vida } \\
\text { de estudantes de } \\
\text { graduação em } \\
\text { Enfermagem. }\end{array}$ & $\begin{array}{l}\text { Investigar a QV dos } \\
\text { estudantes de graduação } \\
\text { em Enfermagem de uma } \\
\text { instituição de ensino } \\
\text { privada no interior do } \\
\text { Estado de SP. }\end{array}$ & $\begin{array}{l}\text { Quantitativa } \\
\text { Índice de QV de } \\
\text { Ferrans e } \\
\text { Powers. }\end{array}$ & $\mathrm{M}$ & EE.USP/SP \\
\hline 2003 & $\begin{array}{l}\text { Cavalcante, } \\
\text { M.B. }\end{array}$ & $\begin{array}{l}\text { Humanização no } \\
\text { processo de } \\
\text { formação de } \\
\text { profissionais de } \\
\text { saúde. }\end{array}$ & $\begin{array}{l}\text { Conhecer as percepções } \\
\text { de alunos de graduação } \\
\text { em enfermagem sobre as } \\
\text { experiências vividas } \\
\text { durante o período de } \\
\text { formação, por eles } \\
\text { consideradas positivas ou } \\
\text { negativas, e conhecer as } \\
\text { estratégias adotadas pelo } \\
\text { professor, como agente } \\
\text { facilitador/dificultador } \\
\text { desse processo. }\end{array}$ & Qualitativa & D & $\begin{array}{c}\text { EE.USP/ } \\
\text { SP }\end{array}$ \\
\hline 2002 & $\begin{array}{l}\text { Costenaro, } \\
\text { RGS; } \\
\text { Lacerda, MR }\end{array}$ & $\begin{array}{l}\text { Quem cuida de } \\
\text { quem cuida? } \\
\text { Quem cuida do } \\
\text { cuidador? }\end{array}$ & $\begin{array}{l}\text { Refletir a respeito do } \\
\text { cuidado daquele que cuida } \\
\text { do outro, em especial } \\
\text { daquele que tem como } \\
\text { essência o cuidado na sua } \\
\text { profissão. }\end{array}$ & Qualitativa & Livro & $\begin{array}{l}\text { UNIFRA/ } \\
\text { RGS }\end{array}$ \\
\hline 2002 & $\begin{array}{l}\text { Iglesias, RB; } \\
\text { Kimura, M }\end{array}$ & $\begin{array}{l}\text { Qualidade de vida } \\
\text { de alunos- } \\
\text { trabalhadores que } \\
\text { cursam a } \\
\text { graduação em } \\
\text { Enfermagem }\end{array}$ & $\begin{array}{l}\text { Analisar a QV de alunos- } \\
\text { trabalhadores que cursam } \\
\text { a grad. Em Enf. e associar } \\
\text { entre a QV desses alunos } \\
\text { e suas características } \\
\text { sócio-demográficas, de } \\
\text { trabalho e estudo. }\end{array}$ & $\begin{array}{c}\text { Quantitativa - } \\
\text { Índice de QV de } \\
\text { Ferrans e Powers }\end{array}$ & $\mathrm{M}$ & $\begin{array}{l}\text { EE.USP/ } \\
\text { SP }\end{array}$ \\
\hline 2002 & Saupe, R. & $\begin{array}{l}\text { Qualidade de Vida } \\
\text { de Estudantes de }\end{array}$ & $\begin{array}{l}\text { Avaliar a qualidade de vida } \\
\text { dos estudantes de }\end{array}$ & $\begin{array}{l}\text { Quantitativa } \\
\text { Escala de }\end{array}$ & Artigo & $\begin{array}{c}\text { Maringá/ } \\
\text { PR }\end{array}$ \\
\hline
\end{tabular}




\begin{tabular}{|c|c|c|c|c|c|c|}
\hline & & Enfermagem. & enfermagem. & Flanagan & & \\
\hline 2002 & $\begin{array}{l}\text { Ligeiro, LR; } \\
\text { Baptista,SS }\end{array}$ & $\begin{array}{l}\text { A exclusão das } \\
\text { alunas de } \\
\text { enfermagem da } \\
\text { Escola Anna Nery } \\
(1930-1938)\end{array}$ & $\begin{array}{l}\text { Revela que a maioria das } \\
\text { alunas excluídas, ao } \\
\text { ingressarem na Escola, se } \\
\text { deparavam com o rigor da } \\
\text { disciplina e com a extensa } \\
\text { carga horária de serviços } \\
\text { diários. }\end{array}$ & $\begin{array}{c}\text { Quanti- } \\
\text { Qualitativo } \\
\text { Histórico Social }\end{array}$ & Artigo & UFRJ \\
\hline 22003 & $\begin{array}{l}\text { Mendes, } \\
\text { AMOC }\end{array}$ & $\begin{array}{l}\text { Stress e } \\
\text { Imunidade }\end{array}$ & $\begin{array}{l}\text { Estudo sobre as alterações } \\
\text { verificadas na condição de } \\
\text { saúde dos alunos de } \\
\text { enfermagem e como } \\
\text { podem ser explicadas por } \\
\text { situações de stress } \\
\text { relacionadas com o curso. }\end{array}$ & Quantitativo & Livro & Coimbra \\
\hline 2001 & $\begin{array}{l}\text { Santiago, LC; } \\
\text { Meireles, CA; } \\
\text { Santos, CO }\end{array}$ & $\begin{array}{l}\text { Sentimentos de } \\
\text { um grupo de } \\
\text { acadêmicos de } \\
\text { enfermagem: } \\
\text { Vivências iniciais } \\
\text { ao cuidar de } \\
\text { clientes } \\
\text { hospitalizados. }\end{array}$ & $\begin{array}{l}\text { Analisar os sentimentos } \\
\text { dos alunos quando iniciam } \\
\text { os cuidados de } \\
\text { enfermagem fundamentais. }\end{array}$ & Quali/Quantitativo & Artigo & UFRJ \\
\hline 2000 & Lucchese, R & $\begin{array}{l}\text { Grupo Operativo } \\
\text { como estratégia } \\
\text { pedagógica em um } \\
\text { curso de } \\
\text { graduação em } \\
\text { enfermagem: um } \\
\text { espaço continente } \\
\text { das vivências dos } \\
\text { alunos } \\
\text { quartanistas. }\end{array}$ & $\begin{array}{l}\text { Oferecer um espaço para a } \\
\text { expressão vivencial do } \\
\text { aluno do quarto ano de } \\
\text { graduação. } \\
\text { Operacionalizar por meio } \\
\text { do grupo operativo, trocas } \\
\text { relacionais que favorecem } \\
\text { o enfrentamento das } \\
\text { ansiedades vividas pelo } \\
\text { aluno. }\end{array}$ & $\begin{array}{c}\text { Qualitativa } \\
\text { Pesquisa- ação }\end{array}$ & $\mathrm{M}$ & $\begin{array}{c}\text { EEUSP/ } \\
\text { SP }\end{array}$ \\
\hline 2000 & $\begin{array}{l}\text { Oliveira, ICS; } \\
\text { Fernandes, } \\
\text { JF; } \\
\text { Lunardi, VL }\end{array}$ & $\begin{array}{l}\text { Como a futura } \\
\text { enfermeira está se } \\
\text { cuidando e vem } \\
\text { sendo cuidada no } \\
\text { processo de } \\
\text { graduação? }\end{array}$ & $\begin{array}{l}\text { Compreender se a } \\
\text { preparação para o trabalho } \\
\text { da futura enfermeira tem } \\
\text { sido constituído num meio } \\
\text { e instrumento de } \\
\text { favorecimento do seu } \\
\text { cuidado e da negação de } \\
\text { si. }\end{array}$ & Qualitativa & Artigo & UFRGS \\
\hline 2000 & $\begin{array}{l}\text { Valente, SH; } \\
\text { Boemer, MR }\end{array}$ & $\begin{array}{l}\text { A sala de } \\
\text { anatomia } \\
\text { enquanto espaço } \\
\text { de convívio com a } \\
\text { morte }\end{array}$ & $\begin{array}{l}\text { Compreender o primeiro } \\
\text { contato que estudantes de } \\
\text { enfermagem e medicina } \\
\text { têm com a morte na sala } \\
\text { de anatomia. Revelam que } \\
\text { muitos alunos relegam } \\
\text { sentimentos de medo e } \\
\text { tristeza, adaptando-se } \\
\text { rapidamente ao } \\
\text { aprimoramento técnico } \\
\text { científico. }\end{array}$ & $\begin{array}{c}\text { Qualitativa- } \\
\text { Fenomenologia }\end{array}$ & Artigo & UFRJ \\
\hline 2000 & $\begin{array}{l}\text { Cruz, C; } \\
\text { Garofalo, RC; } \\
\text { Sabino, T; } \\
\text { Nascimento, } \\
\text { MAL }\end{array}$ & $\begin{array}{l}\text { O "pacote" e a } \\
\text { enfermagem: } \\
\text { ( análise crítica de } \\
\text { uma cena de } \\
\text { morte). }\end{array}$ & $\begin{array}{l}\text { Fornecer subsídios que } \\
\text { possam respaldar as } \\
\text { reflexões sobre a morte. } \\
\text { Situação onde o papel da } \\
\text { supervisora aparece como } \\
\text { ponto de apoio. }\end{array}$ & $\begin{array}{l}\text { Estudo descritivo } \\
\text { Relato de alunos }\end{array}$ & Artigo & UFRJ \\
\hline 2000 & Leite, MTS & $\begin{array}{l}\text { O processo } \\
\text { ensino- } \\
\text { aprendizagem na } \\
\text { perspectiva do ser } \\
\text { professor e do ser } \\
\text { aluno. }\end{array}$ & $\begin{array}{l}\text { Compreender o significado } \\
\text { do processo ensino- } \\
\text { aprendizagem na } \\
\text { perspectiva dos } \\
\text { professores e dos alunos } \\
\text { da } 1{ }^{2} \text { turma de } \\
\text { enfermagem. }\end{array}$ & $\begin{array}{c}\text { Qualitativa } \\
\text { Referencial } \\
\text { Fenomenológico. }\end{array}$ & $M$ & UFMG \\
\hline 2000 & Freitas, KSS; & O cuidado no & Desenvolver um processo & Qualitativa & $\mathrm{M}$ & UFSC \\
\hline
\end{tabular}




\begin{tabular}{|c|c|c|c|c|c|c|}
\hline & Silva, AL & $\begin{array}{l}\text { processo de ser e } \\
\text { viver de educanda } \\
\text { em enfermagem. }\end{array}$ & $\begin{array}{l}\text { de cuidado, com } \\
\text { educandas de } \\
\text { enfermagem. }\end{array}$ & & & \\
\hline 1999 & $\begin{array}{l}\text { Fernandes, } \\
\text { GFM; } \\
\text { Vaz, MRC }\end{array}$ & $\begin{array}{l}\text { Processo de } \\
\text { avaliação } \\
\text { humanizado e } \\
\text { participativo nos } \\
\text { estágios } \\
\text { supervisionados } \\
\text { de enfermagem }\end{array}$ & $\begin{array}{l}\text { Analisar as possibilidades } \\
\text { e limites da construção de } \\
\text { um processo de avaliação } \\
\text { humanizado e participativo } \\
\text { nos estágios } \\
\text { supervisionados de } \\
\text { enfermagem. }\end{array}$ & Qualitativa & M & RGS \\
\hline 1999 & $\begin{array}{l}\text { Cocco, MIM; } \\
\text { Bagnato, MHS }\end{array}$ & \begin{tabular}{|l|} 
Educadores e \\
educandos em \\
enfermagem: \\
possíveis \\
alternativas em um \\
mundo em \\
mudança
\end{tabular} & \begin{tabular}{|l} 
Reflexão sobre as \\
transformações que estão \\
ocorrendo no mundo e \\
suas possíveis implicações \\
nas relações entre \\
educandos e educadores \\
no ensino de enfermagem .
\end{tabular} & Qualitativo & Artigo & UFSC \\
\hline 1999 & $\begin{array}{l}\text { Matheus, } \\
\text { MCC; } \\
\text { Chaves, EC; } \\
\text { Bianchi, ERF }\end{array}$ & $\begin{array}{l}\text { A Relação } \\
\text { professora aluna e } \\
\text { os Mecanismos de } \\
\text { Stress Coping e } \\
\text { Burnout nas } \\
\text { primeiras } \\
\text { experiências } \\
\text { práticas. }\end{array}$ & $\begin{array}{l}\text { Apresenta uma análise dos } \\
\text { dados da pesquisa anterior } \\
\text { realizada por } \\
\text { Matheus(1995) sobre as } \\
\text { primeiras experiências } \\
\text { práticas da aluna e sua } \\
\text { relação com a professora, } \\
\text { sob a perspectiva de } \\
\text { LÀZARUS, FOLKMAN } \\
\text { sobre stress, coping e } \\
\text { burnout. }\end{array}$ & Qualitativa & Artigo & $\begin{array}{c}\text { EEUSP/ } \\
\text { SP }\end{array}$ \\
\hline 1999 & $\begin{array}{l}\text { Silva, MG; } \\
\text { Ruffino, MC }\end{array}$ & $\begin{array}{l}\text { Comportamento } \\
\text { docente no ensino } \\
\text { de graduação em } \\
\text { enfermagem: a } \\
\text { percepção dos } \\
\text { alunos. }\end{array}$ & $\begin{array}{l}\text { Identificar os } \\
\text { comportamentos docentes } \\
\text { predominantes no ensino } \\
\text { de graduação em } \\
\text { enfermagem de acordo } \\
\text { com a percepção dos } \\
\text { alunos. }\end{array}$ & $\begin{array}{l}\text { Levantamento } \\
\text { Quantitativo }\end{array}$ & $M$ & EERP-USP \\
\hline 1999 & $\begin{array}{l}\text { Carvalho, } \\
\text { MDB; } \\
\text { Pelloso, SM; } \\
\text { Valsecchi, } \\
\text { EASS; } \\
\text { Coimbra, JAH }\end{array}$ & $\begin{array}{l}\text { Expectativas dos } \\
\text { alunos de } \\
\text { enfermagem frente } \\
\text { ao primeiro estágio } \\
\text { em hospital. }\end{array}$ & $\begin{array}{l}\text { Os alunos revelam atitudes } \\
\text { de ansiedade quanto ao } \\
\text { procedimentos técnicos, } \\
\text { relacionamento com o } \\
\text { paciente e avaliação. O } \\
\text { docente pode favorecer a } \\
\text { eficácia do ensino e a } \\
\text { humanização da formação. }\end{array}$ & Qualitativo & Artigo & $\begin{array}{l}\text { EE-USP/ } \\
\text { SP }\end{array}$ \\
\hline 1999 & Rocha, EM & $\begin{array}{l}\text { Comportamento } \\
\text { comunicativo do } \\
\text { docente de } \\
\text { enfermagem e sua } \\
\text { influência na } \\
\text { aprendizagem do } \\
\text { educando. }\end{array}$ & $\begin{array}{l}\text { Reflexão sobre o ensino de } \\
\text { enfermagem e a motivação } \\
\text { que o aluno de graduação } \\
\text { tem para o processo de } \\
\text { ensino - aprendizagem }\end{array}$ & Qualitativo & $\mathrm{M}$ & $\begin{array}{l}\text { EE-USP/ } \\
\text { SP }\end{array}$ \\
\hline 1999 & $\begin{array}{l}\text { Filho, PCPT; } \\
\text { Pires, E; } \\
\text { Araújo, GA }\end{array}$ & $\begin{array}{l}\text { Características } \\
\text { evidenciáveis de } \\
\text { estresse em } \\
\text { discentes de } \\
\text { enfermagem. }\end{array}$ & $\begin{array}{l}\text { Detectar e verificar a } \\
\text { intensidade de } \\
\text { características } \\
\text { evidenciáveis de estresse } \\
\text { nos alunos do 8. semestre } \\
\text { do Curso de Enfermagem }\end{array}$ & Quantitativo & Artigo & EEUSP-RP \\
\hline
\end{tabular}

Nota: Elaborado á partir da revisão bibliográfica: Cardoso, SH, Oliveira, RA.; Ciampone,

MHT. (2004)

Ao analisar as publicações, constatamos que há um interesse crescente pelo tema, embora não sejam utilizados os descritores 
de qualidade de vida. Observa-se uma aproximação das dimensões de qualidade de vida ao discutirem processo de ensino-aprendizagem.

Em relação aos métodos utilizados nos estudos são quantitativo e qualitativo, de caráter exploratório, destacando-se como resultados, os diagnósticos de situação e intervenção, esta, caracterizada pela modalidade de pesquisa-ação e pela utilização da técnica de grupos.

Dos estudos encontrados que utilizam a metodologia quantitativa, nos anos de 2003 à 2005, há uma tendência de estudos que avaliam a qualidade de vida a partir da aplicação de escalas de medidas, baseados no conceito de Qualidade de vida proposto pela OMS.

Os demais estudos que adotam a metodologia quantitativa identificam situações que envolvem o stress no início do curso, no fim do curso, e o comportamento docente a partir da percepção dos alunos.

Estes estudos contribuem para diagnósticos de situações tanto em relação ao aluno quanto ao docente.

Ao tratarmos dos estudos de metodologia qualitativa, destacamos algumas contribuições para a abordagem da: a relação professor-aluno como facilitador do processo ensino-aprendizagem com ênfase nas primeiras experiências do campo prático, convívio com a morte, estudo de estratégias como espaços grupais como continente para as vivências dos alunos, processo de avaliação participativo, e cuidado do cuidador considerando também, o cuidado do aluno. 
Os estudos que utilizam as duas metodologias concomitantemente revelam aspectos de exclusão em relação a estrutura escolar e analisam sentimentos dos alunos ao iniciarem os cuidados iniciais aos clientes.

Os trabalhos publicados na sua maioria, são resultados de pesquisas realizadas por autores vinculados a Programas de PósGraduação em Enfermagem.

Este levantamento demonstrou que as publicações nacionais a respeito da temática Qualidade de Vida do estudante de enfermagem embora em um número significativo, ainda apresentam-se insuficientes considerando-se as abordagens qualitativas.

Considerando a carência de estudos mais específicos em diferentes cenários e situações na formação do enfermeiro que determinam e podem gerar tanto processos potencializadores de qualidade de vida, como processos destrutivos da mesma, comprometendo a saúde física e mental do futuro profissional, é que vislumbramos o desenvolvimento da presente investigação que deve gerar conhecimento ao identificar se a Universidade é um espaço promotor ou não de vivência de qualidade de vida para os futuros enfermeiros. 


\section{O CAMINHO METODOLÓGICO}

Atualmente, a abordagem qualitativa compõe em grande parte o cenário metodológico das pesquisas em enfermagem e educação, uma vez que envolve aspectos das ciências sociais que dependem essencialmente da observação da interação entre as pessoas em seus próprios espaços, descritos e expressos através da própria linguagem.

De acordo com Minayo (1996), a metodologia qualitativa é capaz de incorporar o significado e a intencionalidade como inerentes aos atos, às relações e estruturas sociais. A escolha por esta modalidade de pesquisa permite o acesso à intersubjetividade presente no propósito de revelar a compreensão que o aluno tem em relação ao seu vivido, durante a sua formação, quanto a qualidade de vida no trabalho.

A opção pela pesquisa qualitativa caracteriza o quanto compartilhamos com os participantes todos os problemas e possibilidades de atribuir sentido e buscar a compreensão desses processos. Exige, portanto, refletir sobre questões, como o rigor, validação e implicações éticas que estão contempladas durante todo o estudo.

Acredito que a análise das percepções dos alunos de enfermagem sobre a qualidade de vida, respeitando o recorte das vivências percebidas como promotoras e não promotoras de qualidade de vida, permitirá identificar e, provavelmente, reconstituir o significado singular e 
coletivo envolvidos no processo de formação, no cuidar de si. Enfim, uma estratégia que fortalece os sujeitos coletivos para que eles verbalizem, reflitam e permitam o protagonismo na elaboração e construção de formas mais solidárias e humanizadas de sua qualidade de vida.

\subsection{O Cenário do estudo}

O presente estudo foi desenvolvido com os alunos do Curso de Graduação em Enfermagem, do Departamento de Enfermagem do Centro de Ciências Médicas e Biológicas, Campus Sorocaba, da Pontifícia Universidade de São Paulo.

No Campus Sorocaba além do Curso de Enfermagem, estão alocados o Curso de Medicina e o Curso de Ciências Biológicas. São desenvolvidos vários cursos de pós-graduação (especializações).

Os alunos contam com o trabalho da Vice- Diretoria Comunitária ${ }^{3}$ nas seguintes situações: recepção aos calouros, contribui para atendimento ao alunado com dificuldades financeiras a partir de estudo da situação; participação do Programa de Atendimento Comunitário (PAC) no encaminhamento de alunos para assistência psicológica; acolhimento às necessidades de alunos com problemas de saúde e atendimento de alunos do Convênio Itamaraty (alunos estrangeiros).

\footnotetext{
${ }^{3}$ Informações contidas no Regimento Interno do CCMB- PUC/SP, na Seção 4 do Vice Diretor Comunitário, Título II da Organização Administrativa, Cap. 3 e entrevista concedida pela Profa. $\underline{\text { Carmen Lúcia C. Gardenal, Vice Diretora Comunitária do CCMB. }}$
} 
A Vice-Diretoria Comunitária tem como meta o desenvolvimento de equipes de apoio para cada curso, com o objetivo de apoio contínuo ao alunado nas diferentes demandas que forem necessárias.

Em relação ao curso de Enfermagem ,uma característica é a inserção do aluno na realidade de atuação, de forma gradativa, na primeira série. Os alunos são inseridos nas Unidades de Saúde e na Comunidade, pela Disciplina de Saúde Coletiva. Realizam aulas práticas no Conjunto Hospitalar de Sorocaba, nas Disciplinas Enfermagem Fundamental e Semiologia e Semiotécnica de Enfermagem.

Escolhi este contexto, pelo fato de trabalhar nesta Universidade e ser docente deste curso há dez anos, inicialmente, nas Disciplinas de Enfermagem Fundamental e Semiologia e Semiotécnica de Enfermagem na $1^{\text {a }}$ série e, há 4 anos, como coordenadora e docente na disciplina de Enfermagem Cirúrgica na 3.a série.

Como docente, vivo os conflitos do meio onde se desenvolvem as atividades de formação do futuro enfermeiro. Em contato com os alunos nas Clínicas Cirúrgicas, acompanho-os e compartilho com eles situações geradoras de sentimentos de impotência, revolta, tristeza. Exemplificando: a falta de uma abordagem humanizada por parte da equipe (médicos, residentes, professores, enfermeiros e auxiliares) em relação aos pacientes e aos alunos; a organização de trabalho que ainda é centrada nos procedimentos e não na abordagem global à pessoas; situações cirúrgicas onde a intervenção é apenas paliativa. 
Neste contexto, venho trabalhando com os alunos numa perspectiva de acolhimento, permitindo que os mesmos possam expressar seus sentimentos, perceber suas potências e compartilhar no grupo.

O Curso de Enfermagem desta Pontifícia Universidade Católica de São Paulo, há cinqüenta anos vem contribuindo de forma efetiva com a enfermagem brasileira, formando profissionais para atuar em diferentes campos da saúde.

Nos anos 90, em meio a uma crise econômica e política, havia uma notável queda na procura pelo Curso de Enfermagem, o que levou o Departamento a tomar algumas providências para proteger o curso. Houve uma redução das vagas, de 50 para 30 , e o período de integral para semi-integral. (Gardenal, 1996)

Em 1994, houve uma reação de melhora, com aumento significativo da procura pelo curso. Atualmente, o Curso sofreu um aumento das vagas de 30 para 50, com aproximadamente 200 alunos, freqüentando aulas de segunda à sábado, no horário das 7:00 às 12:30 horas.

Apresentamos o quadro a seguir, dados parciais do perfil dos alunos matriculados no Curso de Enfermagem da PUC-SP. 
Quadro 4: $\quad$ Perfil dos alunos matriculados no Curso de Enfermagem no período de 1999 à 2005.

\begin{tabular}{|c|c|c|c|c|c|c|c|}
\hline $\begin{array}{r}\text { Ano } \\
\text { Perfil }\end{array}$ & 1999 & 2000 & 2001 & 2002 & 2003 & 2004 & 2005 \\
\hline Faixa etária & $\begin{array}{l}\text { 17-19 } \\
\text { anos }\end{array}$ & $\begin{array}{l}18-19 \\
\text { anos }\end{array}$ & $\begin{array}{c}18-19 \\
\text { anos }\end{array}$ & $\begin{array}{c}18-19 \\
\text { anos }\end{array}$ & $\begin{array}{c}18-23 \\
\text { anos }\end{array}$ & $\begin{array}{l}\text { 17- } 23 \\
\text { anos }\end{array}$ & $\begin{array}{c}18-29 \\
\text { anos }\end{array}$ \\
\hline Sexo & $\begin{array}{l}\mathrm{F}=36 \\
M=05\end{array}$ & $\begin{array}{l}\mathrm{F}=47 \\
M=03\end{array}$ & $\begin{array}{l}\mathrm{F}=43 \\
M=07\end{array}$ & $\begin{array}{l}\mathrm{F}=43 \\
M=07\end{array}$ & $\begin{array}{l}\mathrm{F}=51 \\
M=01\end{array}$ & $\begin{array}{l}F=45 \\
M=08\end{array}$ & $\begin{array}{l}\mathrm{F}=41 \\
\mathrm{M}=09\end{array}$ \\
\hline casado & 03 & 06 & 05 & 02 & 07 & 02 & 04 \\
\hline solteiro & 35 & 42 & 43 & 45 & 39 & 46 & 42 \\
\hline separado & 03 & 01 & 02 & 01 & 01 & 01 & 01 \\
\hline $\begin{array}{c}\text { Atividade } \\
\text { remunerada }\end{array}$ & $\begin{array}{l}\text { Sim }=18 \\
\text { Não }=23\end{array}$ & $\begin{array}{l}\text { Sim }=15 \\
\text { Não }=35\end{array}$ & $\begin{array}{l}\text { Sim }=20 \\
\text { Não }=30\end{array}$ & $\begin{array}{l}\text { Sim }=15 \\
\text { Não }=33\end{array}$ & $\begin{array}{l}\text { Sim }=22 \\
\text { Não }=27\end{array}$ & $\begin{array}{l}\text { Sim }=22 \\
\text { Não }=28\end{array}$ & $\begin{array}{l}\text { Sim }=22 \\
\text { Não }=28\end{array}$ \\
\hline Escola PT"** & 13 & 15 & 21 & 23 & 19 & 22 & 22 \\
\hline Escola P.** & 25 & 35 & 28 & 23 & 26 & 24 & 28 \\
\hline Cursinho & $\begin{array}{l}\text { Sim }=21 \\
\text { Não }=19\end{array}$ & $\begin{array}{l}\text { Sim }=34 \\
\text { Não }=15\end{array}$ & $\begin{array}{l}\text { Sim }=37 \\
\text { Não }=13\end{array}$ & $\begin{array}{l}\text { Sim }=38 \\
\text { Não }=14\end{array}$ & $\begin{array}{l}\text { Sim }=32 \\
\text { Não }=17\end{array}$ & $\begin{array}{l}\text { Sim }=37 \\
\text { Não }=13\end{array}$ & $\begin{array}{l}\text { Sim }=25 \\
\text { Não }=09\end{array}$ \\
\hline $\begin{array}{l}\text { Total de } \\
\text { alunos }\end{array}$ & 41 & 50 & 50 & 50 & 52 & 53 & 60 \\
\hline
\end{tabular}

Fonte: Dados extraídos de estudo estatístico dos questionários dos candidatos matriculados no Curso de Enfermagem da PUC-SP - Cedidos pela Coordenadoria de Vestibulares e Concursos/PUC-SP

Escola $\mathrm{PT}^{*}$ - oriundos de escolas particulares

Escola $\mathrm{P}^{\star \star}$ - oriundos de escolas públicas

Em relação ao motivo mais forte que levou o aluno a optar pelo curso de enfermagem, ao qual concorreu como $1^{\text {a }}$ opção, foi comum em todos os anos. A saber: adequação às aptidões pessoais e a possibilidade de poder contribuir para a sociedade.

Os alunos matriculados utilizam como meio para se manterem informados sobre os acontecimentos atuais, a televisão, seguindo o jornal e a internet. 
Quanto aos tipos de revistas e jornais mais citados como leitura dos alunos, destacam-se revistas de generalidades (ex. Veja, Isto è, Cláudia, Caras, Vip, Nova, Capricho, etc), e as revistas científicas (ex. Superinteressante, Ciência Hoje, Revista Geográfica Universal, etc.).

Os alunos moram com sua família e o pai é o maior responsável pela renda familiar, com exceção do ano de 2003 , quando as mães é que assumiram este papel.

Quanto ao grau de instrução dos pais, há predominância do ensino médio completo e superior completo. Observa-se que, com o passar dos anos, o grau de instrução dos pais vem melhorando, principalmente no caso das mães. No ano de 2005 , os pais apresentam nível de instrução de ensino médio fundamental completo. Em contrapartida, as mães, se mantêm no nível de ensino médio e superior completo.

Em relação às situações profissionais dos pais, estes são: aposentados, pensionistas, proprietários e/ou administradores de micro empresa, funcionários de empresa privada ou estatal e profissionais liberais.

\subsection{O Currículo do Curso de Enfermagem da PUC/SP}

A Escola de Enfermagem em Sorocaba veio se somar às trinta e quatro escolas existentes até meados da década de 50, e também se incorporou aos $60 \%$ das escolas ligadas à rede privada. 
Após a autorização para o funcionamento da Faculdade de Medicina, em janeiro de 1950, seguem-se esforços para a criação da Escola de Enfermagem.

A Escola de Enfermagem teve início no $2^{\circ}$ semestre de 1950, confiada às Irmãs Franciscanas do Coração de Maria. A autorização para o funcionamento se deu pela Portaria $n^{\circ} 497$, em março de 1951 e passou a funcionar no Hospital Santa Lucinda.

Desde o início da implantação da Enfermagem moderna no Brasil até os dias de hoje, foram estabelecidos seis currículos de enfermagem: em 1923, 1949, 1962, 1972, 1994 e 1996.

Quando surgiu o Curso de Enfermagem em Sorocaba, este veio respaldado no currículo mínimo ditado por força do Decreto $\mathrm{n}^{\circ}$ $27.426 / 49$.

Em 1972, surge então um terceiro currículo mínimo, com duração de três anos, introduzindo as habilitações no lugar das especializações, de forma optativa. A Resolução n04/72 preconizava como objetivo central: "formar os alunos e desenvolver-Ihes uma visão do homem no seu todo biopsicossocial, mas manteve excluída do tronco profissional comum, a área da Saúde Pública, refletindo a hegemonia da prática curativa na atuação da enfermagem". (SILVA, 1991)

O Curso de Enfermagem da PUC-SP, apesar de o currículo mínimo tornar facultativo esse enfoque, tanto na formação geral e optativo 
na escolha da habilitação, garantiu o desenvolvimento da disciplina de Saúde Pública dentro do curso, alocada no $7^{\circ}$ período com uma carga horária de 120 horas, perfazendo 3,07\% da carga horária total, sem habilitação.

Por 22 anos o currículo mínimo de 1972 direcionou o ensino de enfermagem e os destinos da profissão, compactuando com uma política de saúde que privilegiava as medicinas de grupo, o atendimento hospitalar previdenciário, as indústrias farmacêuticas e de equipamentos médico hospitalares. Contudo, é importante destacar que o Curso de Enfermagem da PUC-SP, nunca ficou nos limites da carga horária deliberada pela resolução. Procurou fazer alterações curriculares nas quais a parte preventiva foi cada vez mais ganhando espaço. Antes mesmo de surgir uma nova legislação, extinguiu as habilitações, ganhando o curso mais um semestre para a formação geral dentre outras atitudes tomadas no âmbito operacional.

Na reformulação curricular que ocorreu na década de 70, tentou-se quebrar o predomínio na área curativa aumentando as disciplinas na área preventiva. Foi, então, que surgiu a disciplina de Introdução à Enfermagem em Saúde Pública e Educação em Saúde Pública. Aumentou um pouco a oportunidade de os alunos se prepararem melhor para atuar na área específica, como também para incluir, na prática profissional, as orientações pertinentes a cada patologia, mesmo no ambiente hospitalar. 
Revisando mais uma vez o currículo pleno, em 1990 foi implantada uma nova grade que tentou privilegiar mais ainda a área preventiva, distribuindo no curso as disciplinas de Saúde Pública com um espaço maior, 9,29\%; garantindo outros conteúdos que só se limitavam às habilitações e reorganizando as disciplinas durante os quatro anos.

Somente em dezembro de 1994, ocorre a quinta reforma. Foi fixado, após muitos estudos, o novo currículo de enfermagem, "objetivando estimular a aquisição integrada dos conhecimentos básicos, teóricos e práticos que permitem ao graduando o competente exercício da sua profissão" (Portaria n²1.721,1994).

O Curso de Enfermagem da PUC sempre se manteve além das exigências mínimas regulamentadas para o seu funcionamento, evidenciando a preocupação no sentido de preservar a área de saúde coletiva, quebrando a hegemonia da área curativa. Podemos, também, observar que buscou estar coerente com os valores preconizados pela PUC e os da profissão.

Neste sentido, disciplinas específicas fizeram parte da formação do enfermeiro no Curso de Enfermagem da PUC como as: Antropologia Filosófica, Problemas Filosóficos e Teológicos do Homem, hoje denominada Introdução ao Pensamento Teológico.

Os conteúdos dos aspectos, sociológicos, antropológicos, filosóficos e teológicos, permitem o conhecimento sobre a natureza humana 
e o desenvolvimento de atitudes e valorização do homem, contribuindo para a formação profissional e também para o crescimento pessoal.

Outros conteúdos específicos da formação profissional, foram referentes a: História da Enfermagem enfocando a constituição dos saberes e técnicas ao longo do tempo, permitindo uma melhor compreensão do presente e o redicionamento do futuro; a Ética que estimula a reflexão sobre questões bioéticas suscitadas pela vida, trabalhando-se os conceitos relacionados a pessoa, responsabilidade, respeito, verdade, consciência, autonomia, justiça e outros, que permitem ao aluno perceber o paciente na totalidade de seu ser, bem como a si mesmo.

Em 1996, em atendimento à nova Lei de Diretrizes e Bases da Educação Nacional, a construção do Projeto Político Pedagógico do Curso de Enfermagem da PUC-SP vem tendo planejamento e um considerável investimento que caminha para cinco anos entre encontros, trabalhos individuais e em grupos.

As primeiras iniciativas foram desde a retomada do Currículo em andamento, até as leituras de textos e pesquisas bibliográficas.

A releitura atenta do Currículo Pleno do Curso foi, provavelmente, o primeiro desafio incentivado pelo objetivo de avaliar as diretrizes em curso, as mudanças necessárias e as propostas de novos investimentos. Partiu-se da formação de grupos de trabalhos (GTs) para reconstrução dos marcos referencial e conceitual existentes e da construção 
do marco filosófico, tendo como parâmetro, as contribuições de Saupe e Alves.( 2000)

Novas leituras, encontros com o Prof. José Nagamine (Acessor Técnico da PUC-SP), com o Prof. Dro Marcos Masseto e com as professoras Dr a Regina Marcília e Dr a Terezinha Azevedo Rios, vieram regar o trabalho árduo de revisão da nossa própria prática e visualização de um novo momento na educação de Enfermagem.

No segundo semestre de 2001 o grupo de docentes começou a planejar o Fórum de Avaliação Interna do Curso. As reuniões seguintes foram dedicadas ao planejamento e à organização desse evento.

O Fórum de Avaliação do Curso de Enfermagem (FACE) foi organizado em dois momentos: 1) o primeiro momento ocorreu no dia 22 de novembro de 2001, no horário das 7:00-12:00 h. A dinâmica foi marcada por Oficinas de Trabalho de docentes e alunos por série. As contribuições dos grupos foram apresentadas e o resultado final foi divulgado; 2) o segundo momento foi dedicado aos enfermeiros de campo, egressos da PUC-SP ou não. O objetivo determinado foi: "Contribuir, a partir da vivência prática das (os) enfermeiras (os), com o Curso de Enfermagem da PUC-SP na construção do Projeto Político Pedagógico".

Caminhando no processo de construção do Projeto Político Pedagógico, o grupo de docentes, após muitas discussões, optou pela metodologia problematizadora. Para tanto, vem se preparando por meio de 
cursos de capacitação pedagógica e reuniões frequentes para seguimento da construção da mudança curricular almejada.

A Educação Problematizadora ou libertadora, segundo Paulo Freire, é baseada na concepção de homens que problematizam suas relações com o mundo. Fundamenta-se na relação dialógica entre educador e educando, possibilitando o aprendizado de ambos, por meio de um processo emancipatório. (Freire, 1975)

Neste sentido visualizamos que o perfil de enfermeiro almejado bem como a metodologia problematizadora serão compatíveis com a abordagem de temáticas relativas a Qualidade de Vida integrada nos diferentes módulos do curso, privilegiando a trans e a interdisciplinaridade

\subsection{Os procedimentos para a coleta de dados}

A coleta de dados desta pesquisa ocorreu em dois momentos, sendo que no primeiro utilizou-se como instrumento a entrevista e no segundo momento a técnica de grupos focais.

A coleta de dados teve início após a apreciação e autorização da Comissão de Ética do CCMB-PUC/SP (Centro de Ciências Médicas e Biológicas), de acordo com a Resolução n. 196 (1996), bem como a solicitação de autorização da Chefia do Departamento de Enfermagem para a realização da mesma (Anexos I e II). 
Inicialmente, pedi a participação voluntária e a autorização dos colaboradores do estudo, por meio do Termo de Consentimento Livre e Esclarecido (Anexo III e IV) bem como solicitei autorização para a gravação das entrevistas por eles concedidas. Estes foram informados sobre os objetivos do estudo, a garantia do anonimato, a isenção de qualquer poder hierárquico ou de influências que pudessem interferir em seu vínculo como aluno. Com isso buscamos isentá-los, portanto, de quaisquer pressuposições de natureza coercitiva em decorrência da participação no estudo. Para assegurar o anonimato, os nomes dos colaboradores foram substituídos por pseudônimos, escolhidos pelos próprios colaboradores.

Foram informados da importância da colaboração de cada um para a obtenção de dados e viabilização da pesquisa e que a mesma seria realizada em dois momentos distintos.

\subsubsection{O Primeiro Momento da Coleta de Dados}

\subsubsection{Caracterização dos colaboradores}

Foram convidados nesse primeiro momento os alunos da quarta série do curso de enfermagem, por entender que os mesmos já haviam vivenciado todo o processo de formação e que esse seria um momento oportuno para refletirem sobre o tema qualidade de vida. 
$\mathrm{Na}$ primeira fase deste estudo colaboraram cinco alunas. Antes de iniciar a coleta, expliquei que o conteúdo das entrevistas seria utilizado como temas disparadores a serem discutidos na segunda fase coleta de dados da pesquisa, isto é, nos grupos focais.

No início da entrevista solicitei que cada uma se apresentasse e falasse um pouco de si e de como gostaria de ser caracterizada no estudo. No quadro 5, mostro o perfil das colaboradoras, ressaltando dessa apresentação algumas das características por elas assinaladas.

Quadro 5: $\quad$ Caracterização dos colaboradores da primeira etapa da coleta de dados.

\begin{tabular}{|c|c|c|c|c|}
\hline PSEUDÓNIMO & SEXO & IDADE & ALUNO & FORMAÇÃO \\
& & & TRABALHADOR & ANTERIOR \\
\hline Ana & Fem & 23 & não & Segundo grau \\
\hline Clara & Fem & 32 & Estagiária voluntária & Engenharia \\
\hline Julia & Fem & 21 & não & Segundo grau \\
\hline Maria & Fem & 30 & Sim & Auxiliar de enfermagem \\
\hline Luana & Fem & 27 & Sim & Tecnologia da saúde \\
\hline
\end{tabular}

As colaboradoras nessa etapa foram do sexo feminino, sendo que a mais jovem tinha 21 anos e a mais velha 32 anos, a média das idades foi de 26.6 anos. Podemos considerar que, dentre as participantes, $40 \%$ são alunas trabalhadoras e as mesmas têm formação anterior em nível médio e superior. 
Em relação às experiências prévias na área da enfermagem, destaca-se que apenas uma aluna trabalhadora, exerceu atividades como auxiliar de enfermagem.

\subsubsection{As entrevistas}

O primeiro momento da coleta de dados ocorreu durante 0 mês de novembro e dezembro de 2002.

Os dados foram coletados, por meio de entrevista individual semi-estruturada, com o intuito de favorecer ao entrevistado a possibilidade de discorrer sobre o tema proposto, sem direcionar repostas ou condições pré-fixadas pelo pesquisador, como um meio de acessar tanto conteúdos voltados ao posicionamento do eu quanto às percepções e significados atribuídos ao vivido pelo aluno em relação a sua qualidade de vida.

Este tipo de entrevista constitui-se em um importante recurso de investigação porque nos permite, através do discurso, o acesso a dados de realidade, de caráter subjetivo, isto é, "idéias, crenças, maneiras de pensar; opiniões, sentimentos, maneiras de sentir, maneiras de atuar; conduta ou comportamento presente ou futuro; razões conscientes ou inconscientes de agir". (Jahoda, In Minayo, p.108, 1996)

O instrumento utilizado na coleta de dados (Anexo V) foi constituído por um roteiro contendo três questões abertas. A primeira solicitava que o aluno formulasse o significado de qualidade de vida e, em seguida, solicitava relatos de experiências pessoais ou observadas em seu 
cotidiano sobre aspectos promotores e não promotores da qualidade de vida.

As entrevistas foram gravadas e transcritas na íntegra ${ }^{4}$. Após a transcrição, entreguei as entrevistas aos devidos respondentes para que pudessem tomar contato com o conteúdo produzido em seus depoimentos para que observassem se o que estava escrito correspondia àquilo que haviam dito. Sabendo que era possível modificar o material, em caso de discordância com o texto, desde que não alterasse o significado de suas manifestações, nenhum colaborador propôs alteração na redação das transcrições das entrevistas.

Cabe destacar que o número de colaboradores que participaram da primeira fase da coleta foi definido pelo critério de representatividade das experiências presentes nos discursos. Estes participantes foram por nos considerados porta-vozes do grupo ao qual pertencem.

A análise dessas entrevistas será apresentada adiante, no item correspondente.

\footnotetext{
${ }^{4} \mathrm{O}$ conteúdo das entrevistas na íntegra estão anexados na contra-capa deste relatório em forma de CD $\mathrm{R}$
} 


\subsubsection{O Segundo Momento da Coleta de Dados}

\subsubsection{Caracterização dos Colaboradores}

Para esse momento, foram convidados alunos que estavam freqüentando o curso de graduação em enfermagem matriculados nas segunda, terceira e quarta séries, pois, considerou-se que nessas séries estes vivenciaram pelo menos um estágio na área profissional de aprendizado sejam em Unidades de Saúde, Ambulatórios ou Hospitais. Assim excluiu-se o convite aos alunos da $1^{\text {a }}$ série.

Nesta fase do estudo, participaram onze alunos, representantes das três séries do curso. Os alunos foram identificados por pseudônimos escolhidos por eles mesmos. No quadro 6, saliento, também, o perfil desses colaboradores, ressaltando características presentes na apresentação dos mesmos. 
Quadro 6: Caracterização dos colaboradores da segunda etapa da coleta de dados.

\begin{tabular}{|c|c|c|c|c|c|}
\hline PSEUDÔNIMO & SÉRIE & SEXO & IDADE & $\begin{array}{c}\text { ALUNO } \\
\text { TRABALHADOR }\end{array}$ & $\begin{array}{l}\text { FORMAÇÃO } \\
\text { ANTERIOR }\end{array}$ \\
\hline Lua & $4^{a}$ & $\mathrm{~F}$ & 26 & $\begin{array}{l}\text { Estagiária } \\
\text { voluntária }\end{array}$ & Segundo Grau \\
\hline Sol & 4 & $\mathrm{~F}$ & 23 & não & Segundo Grau \\
\hline Flor & $4^{9}$ & $\mathrm{~F}$ & 21 & não & Segundo Grau \\
\hline Henrique & $4^{a}$ & $\mathrm{M}$ & 32 & $\operatorname{sim}$ & $\begin{array}{c}\text { Tecnologia em } \\
\text { saúde } \\
\text { Técnico em } \\
\text { enfermagem }\end{array}$ \\
\hline Ana & $3^{2}$ & $\mathrm{~F}$ & 23 & não & Segundo grau \\
\hline Gisele & $3^{a}$ & $F$ & 20 & não & Segundo grau \\
\hline Paola & $3^{2}$ & $\mathrm{~F}$ & 22 & não & Segundo, grau \\
\hline Fred & $3^{\underline{a}}$ & $\mathrm{M}$ & 24 & $\operatorname{sim}$ & $\begin{array}{c}\text { Auxiliar de } \\
\text { enfermagem }\end{array}$ \\
\hline Brenda & $2^{\mathrm{a}}$ & $\mathrm{F}$ & 24 & não & $\begin{array}{c}\text { Auxiliar de } \\
\text { enfermagem }\end{array}$ \\
\hline Mel & $2^{\mathrm{a}}$ & $\mathrm{F}$ & 24 & não & $\begin{array}{c}\text { Auxiliar de } \\
\text { enfermagem }\end{array}$ \\
\hline Rosa & $2^{a}$ & $\mathrm{~F}$ & 21 & não & Segundo grau \\
\hline
\end{tabular}

O sexo predominante dos colaboradores nesta fase continua sendo o feminino, representando $81,81 \%$ dos participantes, mas, nesta etapa, contamos com colaboradores do sexo masculino, representando $18,19 \%$, do total.

A média de idades foi de 21,4 anos, sendo que o mais jovem tinha 20 anos e o mais velho 32.

Em relação às experiências prévias na área da enfermagem, destacaram-se: dois alunos trabalhadores do sexo masculino (auxiliar de 
enfermagem) e duas alunas que apenas tinham como experiência na enfermagem, a formação no curso de auxiliar mas que não haviam exercido a profissão.

\subsubsection{Os Grupos}

Para obter os dados no segundo momento, a técnica escolhida foi a de grupo focal, associada a alguns elementos do grupo operativo, conforme proposto por Pichon-Rivière. (2000)

Este momento da pesquisa ocorreu no período entre 13/08/2004 e 17/09/2004, e constituiu-se pela realização de cinco encontros de grupo focal, em que os temas abordados foram embasados no conteúdo que emergiu do conjunto das entrevistas individuais. Desse modo os temas disparadores foram os significados de qualidade de vida e os relatos de vivências durante a formação, vinculados a experiências promotoras ou não promotoras de qualidade de vida.

Segundo Minayo (1996), a técnica de Grupo Focal é importante para o estudo das representações presentes em um dado grupo social, porque ela, de certo modo, simula conversações espontâneas pelas quais as representações são veiculadas no cotidiano.

Chiesa e Ciampone (1999) afirmam que a Técnica de Grupo

Focal pode enriquecer e ampliar a perspectiva de compreensão em uma 
pesquisa, assim como possibilitar intervenções transformadoras que contribuam para interações mais humanas e efetivas.

Justifica-se, ainda, a escolha desta estratégia metodológica pela possibilidade de reunir diferentes atores em formação, num mesmo espaço de investigação, promovendo a reflexão crítica sobre o cotidiano de ensino - aprendizagem. Enquanto estratégia metodológica permite, ainda, aos pesquisadores, observar pontos consensuais e as divergências, além das diferentes maneiras de superação dos problemas evidenciados em diferentes campos que compõem os cenários (Chiesa e Ciampone, 1999)

Elegemos a perspectiva dialética de abordagem grupal, partindo da afirmação de Pichon-Rivière (2000), "de que o sujeito não é só um sujeito relacionado, é um sujeito produzido em uma práxis”.

Pichon-Rivière (2000) define grupo como sendo "um conjunto de pessoas ligadas entre si por constantes de tempo e espaço e articuladas por sua mútua representação interna que se propõe explicita ou implicitamente a uma tarefa, que constitui a sua finalidade."

Em relação à proposta explícita, esta corresponde à tarefa, enquanto motivo pelo qual as pessoas estão reunidas. O implícito é o pano de fundo da interação grupal, é a base que sustenta a persecução do motivo, conforme explicam Ciampone e Dall'Agnol. (1999)

Portanto, esta investigação pautada na técnica de grupos focais, segundo estes pressupostos, constituiu-se em uma modalidade de 
pesquisa-ação (Minayo,1996). Contemplou uma reflexão sobre um problema coletivo de forma coletiva, onde pesquisador e participantes estavam envolvidos de maneira cooperativa e participativa. Os atores, neste cenário, são sujeitos partícipes de todo o processo.

Segundo Ludke e André, (1986) nesse tipo de investigação, o pesquisador se coloca no meio da cena pesquisada, ficando ligado à realidade.

Minayo (1996), Chiesa e Ciampone (1999) consideram como pré-requisito para a operacionalização do grupo focal a existência de um número de participantes que compõem o grupo que não comprometa 0 processo de comunicação. Os relatos encontrados na literatura apontam que o número ideal de participantes que constituirão os grupos oscile entre um mínimo de seis e um máximo de 12 pessoas.

\section{Ciampone e D’Agnoll (1999) esclarecem que os grupos} focais são reuniões com um pequeno número de informantes (de seis a 15), que devem contar com um moderador para intervir, no sentido de focalizar e aprofundar a discussão. Os participantes precisam ser escolhidos a partir de um grupo de referência, cujas vivências sejam pertinentes ao objeto de estudo na pesquisa, isto é, neste tipo de pesquisa a amostra é sempre intencional.

O êxito da aplicação desta técnica vem sendo apontado, em grande parte, pela atuação do coordenador que deve garantir um ambiente que possibilite a expressão de todas as opiniões dos participantes sem que 
isso leve a um clima de disputa. O coordenador deve ser alguém que atue como facilitador do processo.

Outra habilidade do coordenador é manter a discussão sobre o tema central, fazendo sumarizações da discussão, sempre que necessário, auxiliando o grupo a fazer uma reflexão conjunta, ou a trazer novas questões para aprofundamento.

Um papel importante do coordenador é fornecer informações acerca do encontro, esclarecendo sobre os objetivos e finalidades da Pesquisa bem como da Técnica de Grupo Focal. Isto facilita o sentimento de união no grupo. Reduz a ansiedade e elimina mal-entendidos.

O coordenador também deve estar atento à observação da comunicação não verbal do grupo, para que possa evidenciar uma maior diversidade de opiniões ou sentimentos relacionados ao tema em foco, muitas vezes expressos de modo não explícito.

Tratando-se de uma técnica que visa explorar a subjetividade dos atores envolvidos, a operacionalização desta observação mais apurada deve ser feita de modo conjunto pelo coordenador e no mínimo por um observador. Este observador deve assumir a tarefa de registrar todos os acontecimentos no grupo, incluindo os aspectos não verbais presentes na comunicação dos participantes, desde o início até o final da reunião. 
Nesse estudo, a observadora escolhida foi uma terapeuta ocupacional com formação em coordenação de grupo operativo e experiência em observação. A escolha desta observadora teve como requisito ser uma pessoa do conhecimento da pesquisadora que participou da formação em coordenação de grupos, além de ser uma profissional da área da saúde.

As datas e horários dos encontros foram agendados conforme a disponibilidade da maioria dos alunos. Os encontros foram realizados em local que favoreceu a participação, pois o anfiteatro escolhido situa-se dentro do campus do Centro de Ciências Médicas e Biológicas da PUC/SP.

Seguindo os pressupostos do trabalho de Grupo Focal, por ocasião do primeiro encontro, foi realizado o contrato grupal, momento em que o participante, de posse do Consentimento Livre e Esclarecido foram informados sobre os objetivos e aspectos relevantes da pesquisa, de maneira a não permanecerem com dúvidas. Foi também explicado a importância das gravações dos encontros, indicando que o principal motivo consistia na retomada fidedigna do conteúdo para análise posterior. Explicou-se que o uso desse material é exclusivo da pesquisa em curso, bem como que o destino das fitas seria a guarda pela pesquisadora.

Desde o contrato afirmou-se que conteúdos tratados e discutidos nestes encontros seguiriam a ordem: no primeiro, a questão referente aos significados de qualidade de vida, no segundo, reflexão sobre 
os relatos vividos de situações promotoras de qualidade de vida; no terceiro, reflexão e dramatização sobre as situações vividas não promotoras de qualidade de vida. No quarto encontro, combinamos debater o tema Como Construir a Qualidade de Vida, durante a formação, e no quinto encontro, foi acordado uma devolutiva das sessões anteriores e avaliação do processo grupal. Foi esclarecido que a observadora estaria presente em todos os encontros e que a mesma, também faria o registro do processo. Esse material retornaria ao grupo em forma de devolutiva que antecederia o encontro seguinte e ao final.

\subsection{Procedimentos de Análise dos dados.}

$\mathrm{Na}$ primeira fase, o material obtido nas entrevistas foi analisado segundo perspectiva da análise de conteúdo proposta por Minayo (1996).

A Análise de conteúdo pode ser definida como:

“Um conjunto de técnicas de análise de comunicação visando obter, por procedimentos sistemáticos e objetivos de descrição do conteúdo das mensagens, indicadores (quantitativos ou não) que permitam a inferência de conhecimentos relativos às condições de produção/ recepção destas mensagens". Bardin, In Minayo, p. 199, 1996)

$\mathrm{Na}$ busca de atingir os significados manifestos e latentes no material qualitativo, têm se desenvolvido várias técnicas como Análise de 
Expressão, Análise das Relações, Análise Temática e Análise da Enunciação. (Minayo, p.204,1996) Nesta fase do estudo optamos pela Análise Temática, por ser uma das formas que melhor se adequa à investigação em curso.

A opção pela análise temática possibilitou apreender opiniões, atitudes, valores e crenças dos participantes acerca das questões vivenciadas no cotidiano. Partindo do senso comum elabora-se, difunde-se e partilha-se diversas percepções e representações sobre a qualidade de vida.

Segundo Minayo (1996), a análise temática consiste em desvendar "os núcleos de sentidos" contidos nas comunicações, cuja presença ou freqüência tem algum significado importante para os sujeitos que vivenciam determinadas circunstâncias presentes no seu dia-a-dia, relativas ao objeto de estudo.

A análise temática pode se encaminhar para a contagem de freqüência das unidades de significação como definidoras do caráter do discurso. Ao contrário, dessa perspectiva optamos nessa fase pela análise qualitativa da presença de determinados temas convergentes ou divergentes, independentemente da frequência, pois consideramos que esses temas denotam valores de referência e modelos de comportamentos subjacentes aos discursos dos alunos participantes.

Assim, a análise temática pautou-se no processo de formação dos futuros enfermeiros, visualizando-se como finalidade, compreender e intervir no pensar, sentir e agir, que norteiam esses alunos, 
na construção cotidiana da sua qualidade de vida, viabilizando-se essa intervenção mais efetiva no segundo momento da pesquisa, isto é, nos encontros grupais.

\subsubsection{Apresentação e análise das Entrevistas.}

O material resultante das entrevistas individuais foi analisado em duas fases: na primeira, foi feito uma pré-análise. Inicialmente realizei uma "leitura flutuante" do material, num contato exaustivo com os dados, até atingir uma "impregnação" por esse conteúdo. Na segunda fase, realizei a exploração do material, recortei dos dados as unidades de significados e agrupei-as de acordo com os conteúdos, que incidiram em um tema. Para esta fase, elaborei quadros individuais para cada tema disparador dos discursos, conforme mostra o Anexo $\mathrm{VI}$, utilizado para codificar as entrevistas.

Apresento a seguir a síntese dos temas emergentes das questões formuladas nas entrevistas, que posteriormente foram trabalhados nos cinco encontros grupais.

As alunas referiam-se a qualidade de vida como um equilíbrio entre a vida profissional e pessoal. Relataram com maior facilidade as vivências não promotoras de qualidade de vida. Afirmaram que o apoio psicológico, as crenças, os valores e a religião do indivíduo são as bases para manter este equilíbrio. Apontaram momentos de vivência em algumas 
disciplinas como promotoras de qualidade de vida para si e para o cliente. As situações não promotoras de qualidade de vida foram expressas por relatos do convívio com alguns docentes e pela recepção por parte dos enfermeiros de campo. Dificuldades de estrutura, material e integração entre a equipe médica e de enfermagem, foram também citadas como situações não promotoras de qualidade de vida.

Outra questão comentada como não promotora de qualidade de vida foi em respeito a situação do aluno trabalhador e a excessiva carga horária do curso. Revelaram que as situações de conflito como: lidar com o descaso da equipe médica, descaso do familiar em relação ao paciente e a morte, geram sentimentos de impotência e de solidão nos alunos.

A valorização e reconhecimento do cuidado prestado pelo aluno ao paciente, familiares, equipe e professores são percebidos como situações promotoras de qualidade de vida.

\section{Sobre os significados de qualidade de vida}

As alunas percebem qualidade de vida como poder fazer o que gostam e terem tempo para o trabalho e para a vida pessoal ( família, lazer e o cuidado de si), conforme ilustra o trecho da fala;

"Ter qualidade de vida no trabalho significa em primeiro lugar a pessoa ter que gostar do que faz, se ela não gosta, ela não vai ter vontade de fazer o trabalho, vai fazer só por obrigação, pelo dinheiro, ou por outra coisa, se ela gosta do que faz ela vai se sentir melhor."( Ana) 
Para manter-se em equilíbrio, sem ter sobrecarga e estress, apontam o lazer como atividade terapêutica, o apoio psicológico, a família, ter uma fé e religião, como meios de sustentação.

"Porque qualidade de vida é isto, não viver só em função do trabalho, você não pode se sobrecarregar, não pode se estressar, e eu acho que para evitar isto, precisa ter uma atividade terapêutica, ter família, apoio psicológico, em todos, mas eu acho que é muito preciso, ter uma religião, uma fé." (Clara)

Percebem que a estrutura organizacional, bem como as relações interpessoais, devem oferecer condições adequadas para a realização do trabalho. O ambiente harmonioso entre as pessoas e a oportunidade de uma educação continuada aos profissionais, são também valorizados como aspectos significativos para a qualidade de vida.

“...um lugar que funcione uma estrutura adequada, para que você possa exercer suas funções adequadamente. Não só o local, mas, toda a parte que ela possa ter estrutura física e também a parte burocrática tem que oferecer isto." (Julia)

“...Ah! que também tenha espaço para o profissional poder se manter atualizado, freqüentar cursos, congressos... Isto reflete na qualidade de vida, porque o profissional que não se atualiza não pode prestar uma assistência adequada."(Maria) 


\section{Sobre as situações promotoras de qualidade de vida}

As aulas de Antropologia, Psicologia, Psiquiatria e atividades acadêmicas, são referidas pelas alunas como promotoras de qualidade de vida.

"Na aula de psiquiatria, a professora sempre fala que precisa cuidar da mente...eu estava muito estressada...isto tudo me ajudou muito a pensar em mim, a falar o que eu penso e buscar o que eu quero mesmo. Mudei bastante." (Ana)

“...matérias também, psicologia, antropologia, que fazem parte das ciências humanas, elas ajudam a conhecer mais não só o paciente, como a gente também, e entender melhor a vida." (Ana)

“...alguns trabalhos que a faculdade faz, a Semana da Enfermagem, que trata um pouco da parte psicológica, que fala da humanização, acho que isto abre um pouco a nossa cabeça também." (Clara e Luana)

Enumeram vivências que mostram a percepção da relação professor aluno como possível promotora da qualidade de vida.

"Em alguns estágios, não todos, eu vi muita gente trabalhando com gosto, alguns professores também. Você percebe que eles tentam passar segurança, 
entendem seus problemas e procuram dar um certo apoio e eu penso que isto ajuda bastante." (Clara)

"Alguns professores ...você percebe que faz o que gosta e de certa forma incentiva e estimula você...ela ensina com alegria, com entusiasmo, ela respeita 0 paciente, fala baixo, não grita, trata bem os pacientes, os auxiliares, o astral dela é bom." (Clara)

As representações sobre o que é ter Cidadania e Conquista dos Direitos com consciência dos Deveres, também constitui-se como tema quando indagou-se sobre situações promotoras de qualidade de vida.

“Eu penso que qualidade de vida tem muito haver com cidadania, porque você exercendo sua cidadania você vai ter uma qualidade de vida melhor. Lutar por aquilo que a gente acredita, buscar nossos direitos, exercer nossos deveres, respeitar, saber o seu espaço. Eu penso que cidadania é ligado com qualidade de vida." (Julia)

Outro tema foi o apoio dos outros. Nas entrevistas houve o relato de situações onde o apoio recebido pelo aluno pela equipe do setor onde estagiaram foram significativos para as experiências promotoras de qualidade de vida.

“... é ser bem recebido no setor. Poder contar com os enfermeiros, que eles dêem atenção, porque às 
vezes a gente quer perguntar alguma coisa e não consegue nem ser ouvido." (Luana)

Quanto ao resultado do cuidado prestado, os alunos citaram que quando o cuidado prestado resulta em melhoria dos pacientes ou grupos da comunidade, estes sentem-se gratificados e isso também promove a qualidade de vida

"Ah! mas é gostoso você vê alguém que está ali encolhida, deprimida e você consegue animar esta pessoa!! Eu gosto!! Tá na alma, você deita dormir, você está até mais leve, já inclui o paciente nas suas orações." (Maria)

Algumas situações vividas nos estágios são relatadas como mudança de atitude e de valorização da vida. Nesse sentido, percebem que mudou seus valores reconhecendo riscos e a importância de cuidar de si, também são fatores promotores de qualidade de vida.

“... depois que eu fiz estágio no Pronto Socorro, eu vi muitos acidentes de moto, então, talvez tenha melhorado a minha qualidade de vida, porque eu não vou mais andar de moto. (Maria) 


\section{Sobre as situacões não promotoras de qualidade de vida}

Relatam que a Introdução ao Hospital e o contato com os doentes e a realização de procedimentos, gera angústia, medo e as vezes traumatiza o aluno, se o docente não for continente.

“Ah!! Os estágios. No primeiro ano nossa!! O medo da Profa. $Z$ que pelo amor de Deus!!! Então no começo foi muito difícil, eu não sei, eu acho que se a disciplina não tivesse tanto procedimento, deveria ter mais sensibilidade, eu tinha muito medo de fazer um procedimento errado, de ter uma reclamação da professora, então eu sentia muito medo de chegar. Talvez se fosse de outra forma eu teria aproveitado mais os estágios, eu ficava com medo mesmo, a disciplina me agonizava muito e eu ficava com muito medo, me estresso, eu tinha medo, mas assim, o bom é que eu não desisti da profissão." (Ana)

As atitudes negativas do professor que demonstra falta de carinho, tolerância, de paciência e de ética com os alunos nessa fase inicial da aprendizagem pode ser não promotora de qualidade de vida.

“... porque tem professores que não tem muita ética, não tem paciência, as vezes ele chama a atenção em frente do paciente, eu acho que isto é uma situação muito desagradável, principalmente se for no inicio do curso, que a pessoa está crua ainda, este é um ponto negativo." (Clara) 
"A gente respeita muito a profissão de professor...mas, eu acho que tivesse um pouco mais de educação ia melhorar muito a qualidade de vida." (Luana)

A falta de relacionamento entre os alunos da Enfermagem com professores e alunos de outros cursos também foi mencionado enquanto tema não promotor de qualidade de vida.

“...falta um pouco de relacionamento, amizade mesmo, entre as faculdades, por exemplo: enfermagem, medicina, biologia, eu penso que tem muito preconceito em relação a isso."(Clara)

As atitudes negativas do Enfermeiro de campo demonstrando desatenção ao paciente, resultando em desestímulo para o aluno e descaso em relação ao cuidado. Para eles o enfermeiro de campo é, de certo modo, um modêlo ou um anti-modêlo

“Ela não se preocupa com a equipe, ela nem sabe o nome dos pacientes, ela não faz assistência direta, nem prescrição de enfermagem, nem nada." (Clara)

A carga horária do curso e as condições de aprendizagem para o aluno trabalhador, também foram lembradas como não promotoras de qualidade de vida. 


\begin{abstract}
“...porque eu estava trabalhando, até que, eu podia ter rendido, produzido coisas melhores, eu gostaria de ter participado em um trabalho cientifico na faculdade, mas o meu tempo para pesquisar fora foi muito escasso." (Luana)
\end{abstract}

"Na nossa sala acho que tem mais uns 10 alunos que trabalham, por isto que eu vejo tem aluno que se doa tanto que chega a adoecer." (Maria)

Os relatos onde os alunos percebem a falta de suporte para o enfrentamento de situações vividas ocasionaram sentimentos por eles nominados como solidão, revolta e culpa.

“...eu via a vida se esvair, e se fosse minha mãe, se fosse... acha que eu ia ficar parada? Mas nunca!! Porque eu me senti culpada de não ter feito alguma coisa...E ali na emergência, ainda mais aluno, fica desesperado..."(Julia)

"Gerou sentimentos de revolta, sentimentos de muitos porquês e sem resposta, isto que é mais triste!" (Júlia) 


\subsubsection{Apresentação e análise dos Grupos}

A explanação sobre os cinco encontros do grupo focal está apresentada no item 4.4.2.1.

O material dos encontros grupais foi primeiramente gravado e transcrito servindo como base para a elaboração das crônicas e para a constituição da discussão, análise e síntese final da pesquisa.

Os dados advindos dos encontros também foram submetidos a uma "leitura flutuante" com o intuito de alcançar uma “impregnação” pelo conteúdo.

Ao término de cada sessão realizávamos uma breve análise do material produzido pelo grupo. Para tanto, eu e a observadora nos reuníamos para analisar o conteúdo apreendido tendo apoio nas anotações realizadas no encontro. No momento dessa primeira análise, estávamos atentas ao que os porta - vozes ${ }^{5}$ do grupo tinham tentado nos comunicar. No encontro seguinte, eram apontados ao grupo os vários aspectos explicitados pelos porta-vozes que eram também do grupo, ou seja, decorrentes da interação dos membros do grupo entre si e com o coordenador.

Segundo a técnica de grupos operativos as crônicas elaboradas pelo coordenador e observador devem refletir os principais

\footnotetext{
${ }^{5}$ Porta-voz é o depositário da ansiedade grupal, conjuga a verticalidade e a horizontalidade, isto é, fala de sua vida pessoal articulando-a com o processo atual que acontece no aqui e agora de grupo em relação a tarefa. O que é enunciado pelo porta-voz, no grupo, torna-se conteúdo emergente a ser interpretado. (Pichon-Rivière (2000).
} 
momentos vividos pelo grupo em relação à tarefa. As crônicas de cada encontro, constituíram-se em material de apresentação dos dados neste momento da pesquisa.

No capítulo denominado "Discutindo os Encontros", buscamos estabelecer os nexos entre os domínios da QVT. e, QVTE e QVEst.Enf., apontados pela literatura, frente às crônicas consideradas material empírico produzido nos encontros.

\subsubsection{O Primeiro Encontro}

\section{Devolutiva das entrevistas individuais - 13/08/2005}

O primeiro encontro começou às 15 horas, em um Anfiteatro do Hospital Santa Lucinda, localizado dentro do Campus, pois o prédio da Faculdade estava passando por reformas e o barulho iria interferir.

Os alunos estavam alegres, motivados. Logo que encontraram as cadeiras foram-se acomodando.

Neste primeiro encontro estavam presentes: eu, no papel de pesquisadora e coordenadora do grupo, a observadora e 11 dos 12 alunos convidados a participar: 3 alunos da $2^{\underline{a}}$ série do curso, 4 alunos da $3^{\text {a }}$ série e 4 alunos da $4 \stackrel{a}{ }$ série.

O início do encontro se deu com minha fala, agradecendo a presença de todos, e reafirmando com os participantes o objetivo do 
contrato estabelecido, reafirmando os objetivos da pesquisa, apresentando e expondo a função de um terceiro elemento do grupo, a observadora, estabelecendo-se os horários, datas e local onde ocorreriam os demais quatro encontros do grupo focal (GF).

Expliquei a importância de gravar os encontros e todos concordaram.

Fizemos uma rápida apresentação dos presentes, pois, já eram conhecidos do meio acadêmico: nome e série. Neste momento, distribui papel e caneta para que eles escolhessem e escrevessem como gostariam de ser chamados por um nome fictício e que deixassem exposto para facilitar a visualização. Percebi que gostaram da idéia e logo já foram surgindo seus novos nomes, alguns variaram as cores e fizeram ilustrações.

Esclareci que, naquele primeiro encontro, eu apresentaria uma devolutiva, uma análise do material resultante de cinco entrevistas individuais realizadas com alunos da 4.a série do ano de 2002. Expliquei ainda que os dados coletados foram analisados depois de terem sido divididos em temas e subtemas emergentes, respeitando os princípios da análise qualitativa de dados propostos por Minayo (1996).

Falei que a cada encontro abordaríamos as respostas de cada questão formulada nas entrevistas individuais. 
Estavam todos atentos. Expliquei que poderiam manifestar suas opiniões de forma livre. Acrescentei que deveriam ficar à vontade, pois a finalidade dos encontros era estabelecer uma reflexão.

O esquema 1 mostra os significados referentes à qualidade de vida, citados pelos colaboradores.

$1^{\text {a }}$ Questão: Tomando como referência as experiências que você tem tido nos estágios que faz parte de sua formação profissional, o que você considera que é ter qualidade de vida no trabalho?

Apoio Psicológico/ Crenças/ Religião/ Valores

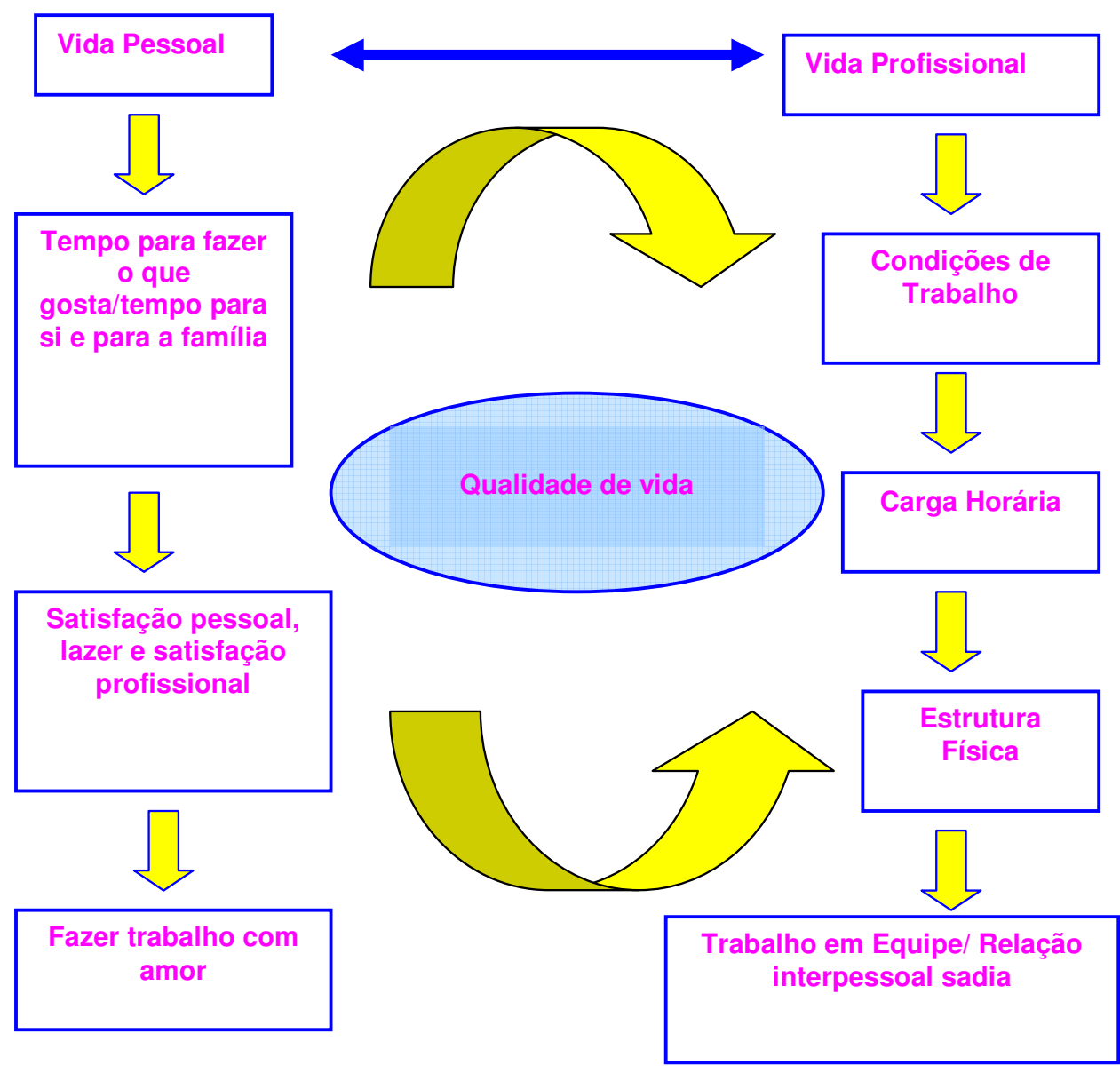


Foram relatados por mim depoimentos dos alunos que ilustravam essas categorias encontradas.

Após terminar a apresentação, perguntei ao grupo: “o que pensam? O que acham e se tem alguma coisa a ver com vocês”.

O grupo se coloca ressaltando pontos sobre as condições de trabalho do profissional enfermeiro como carga horária de trabalho excessiva, remuneração inadequada, falta de material, exploração por parte das empresas.

Henrique expressa “ ... carga horária excessiva, não está aí a remuneração (olha para o esquema apresentado) mas vai pesar muito. As empresas estão cada vez mais visando o enfermeiro como produto mesmo, produtividade, cada vez mais como mão de obra barata,...aí torna-se difícil, é um conflito mesmo...acaba se decepcionando com todo este clima.

Em seguida, passam a ser expostas questões mais próximas da realidade vivida pelos estudantes e os sentimentos envolvidos.

Rosa relata: “Eu acho que falta ao professor ter um jogo de cintura, para lidar com essas dificuldades que a gente enfrenta no estágio, para nos ajudar, lidar com a falta de material. Parece que eles não estão nem sabendo lidar com isso, como se a pessoa que não está bem não sabe dar apoio....fala que quando for profissional vai ser assim, você não vai ter quem lhe dê apoio...". 
Outro ponto ressaltado é a insegurança projetada para o futuro profissional, a partir da percepção da não valorização das atividades do aluno por parte de outros profissionais.

Ana desabafa: “... o estágio é uma coisa importante, será que quando eu me formar vou conseguir trabalhar em equipe, dar uma assistência adequada, conseguir fazer uma prescrição a ser cumprida, a ser feita...a gente estudou tanto para fazer isso, será que eu como chefe vou conseguir, será que os meus auxiliares vão ser capazes?...E fico saindo irritada do estágio, ninguém leu". Aqui a aluna se refere às anotações de enfermagem.

Flor conta uma história de uma colega enfermeira e enfatiza a falta de acolhimento dos colegas enfermeiros e das dificuldades vividas no início da profissão. Revela o seu medo diante da proximidade da sua formatura.

“... ela trabalha em UTI. Contou que no começo foi muito difícil; ela quase entrou em depressão, aliás ela entrou em depressão grau I. Teve que fazer terapia, teve que conversar muito, porque o ambiente é muito difícil. Ela pensou que os colegas enfermeiros iam ser o apoio dela e ela viu que eram os últimos a contar, foram os que mais denegriram... (isso eu percebi aqui na faculdade que tem gente maravilhosa na enfermagem, mas o pior defeito dela é não ter companheirismo entre os próprios enfermeiros) e ela me contou isso". Eu estou super preocupada esta 
semana. Com freqüência estou com isso na minha cabeça. Acho que os auxiliares vão falar que sou novinha, e não sei nada. Ela disse que não. Os auxiliares foram os que mais a ajudaram; então, isso Ihe surpreendeu. Isso não sai da minha cabeça, estou a 3 meses da minha formatura e o mercado de trabalho? Estou morrendo de medo, como vai ser comigo?

O grupo então coloca o que em sua opinião está mais diretamente relacionado com a qualidade de vida e o quanto o tema está intimamente ligado, não somente na vida profissional como pessoal também, de maneira a fazer parte do cotidiano de cada um: "A qualidade de vida, a gente tem que se preocupar todo dia, toda hora ... a gente é exemplo sendo da área a saúde...”. Afirma Lua

Fred relata uma situação vivida em seu trabalho: "Não dá para separar o pessoal dos seus problemas da vida ... o pai dela (colega de trabalho) teve um AVC ... a gente entendeu ... acima de tudo nós somos seres humanos ...”.

São também mencionados como fatores que interferem na qualidade de vida o papel da instituição de ensino e a relação com enfermeiras formadas e com as demais categorias profissionais no convívio hospitalar. 
Sol diz “... porque essa questão de não ter atividades para os alunos? Deve haver atividades para os alunos ... a instituição não tem essa preocupação". Refere-se a espaço de acolhimento e lazer.

Referem ainda o quanto a medicina é privilegiada em relação à enfermagem na questão dos espaços de lazer não compartilhados no campus aos demais cursos. Henrique desabafa: "até o final do curso eu dou um mergulho naquela piscina."

Mel fala do seu medo: "eu fico com medo ... eu não vejo a gente ser apresentada para a enfermeira chefe ..."; "parece que nem sabe o nome. Também elas passam e nem olham para gente ... Eu me sinto um nada ... essa interação, apresentação é muito importante... mas muita gente não quer ouvir isso ... é a nossa instituição ...”.

Paola queixa: "Não tem uma multidisciplinaridade ... você faz uma coisa e eles desfazem ... você acaba perdendo o respeito pela pessoa (colega de trabalho) do seu lado ..."

Em seguida começam a explorar as razões pelas quais os conflitos entre categorias profissionais ocorrem na prática clínica e a refletir sobre sua implicação nisso.

Henrique diz que "... a gente não tem um trabalho conjunto com os alunos da Medicina (durante a formação) ... a partir do momento que você está trabalhando ... junto com o residente esse contato vai ser diferente...."; 
Rosa acrescenta “... na verdade a gente está aqui falando de preconceito, No primeiro dia de aula, os alunos já falam que os médicos são os reis. Cuidado! A gente entra ouvindo isso e vai criando isso durante o curso e não quebra essa impressão que já colocam para nós....”.

Ao final se dão conta de uma questão importante sobre a própria atitude: Mel diz: "percebe que parece que você tem que provar algo para ele?” ; Lua acrescenta: “... é uma questão de valores não é! A gente acha que a gente tem que provar uma coisa ...".

Neste momento, eu, resgatando algumas falas sobre 0 reconhecimento profissional questiono: "o que será que estaria permeando no processo de formação que leva vocês se sintam não valorizados por estarem na enfermagem?"

São retomados pontos como a organização da faculdade, o difícil relacionamento com alunos dos outros cursos durante os estágios, a competitividade dentro da enfermagem. "A faculdade não dá estrutura para a enfermagem ...”; “... a gente não tem autoridade, você escreve ... ninguém lê".; "deveriam ser promovidas atividades de integração ...” ; “... a nossa classe não tem união ..."; “... eles unidos conseguiram a quadra ... não sinto união na enfermagem" e acrescentando a relação com os docentes que em alguns casos é vista como geradora de medo, insegurança e pressão: “... às vezes eu sinto mais ameaçada por professor, eu tenho medo ... mais medo que de qualquer outra coisa ...”. 
Em seguida, mencionam o âmbito familiar como interferindo significativamente na sua qualidade de vida: “... acho que a família é importante ... é o apoio que a gente tem, pelo menos eu sempre tive ..."

Expressam algumas dimensões percebidas como qualidade de vida a partir de atitudes, tanto no âmbito familiar, como profissional.

"Qualidade de vida é um tema que abrange muita coisa. Como pessoa e se dar bem como profissional, claro que você não pode...não dá para separar, você tem que ter um equilíbrio, responsabilidade, ter seu compromisso com amor, tanto com a Instituição quanto com a sua família".

Henrique acrescenta o âmbito pessoal, descreve a partir da leitura de um livro que está fazendo, como o autor (um médico) fala do sofrimento gerado a partir do conflito de enfrentar situações profissionais diferentes dos contextos vividos durante a formação.

"O autor fala de todos os conflitos que ele se depara na Instituição que ele trabalha, em uma cidade em Minisota, e ele lembra na faculdade os pontos que eram abordados, lembra que eram debatidos por semanas por um grupo de médicos e no entanto ele está a 5 minutos do paciente, tem mais 30 minutos para resolver o problema e ele não consegue achar uma solução, ele entra em conflito todo o tempo." 
Ao final, após retomar alguns pontos importantes trazidos pelo grupo, convido-os, para que cada um mergulhe dentro de si e procurem perceber o quanto conseguiram melhorar, buscar o que tem de positivo.

A sessão foi encerrada às 17:00 horas. Agradeci a presença de todos e confirmei a data e local do próximo encontro.

\section{Minhas impressões}

Ao final da sessão todos pareciam estar bem à vontade, considerando tratar-se do primeiro encontro o grupo se colocou bastante e com considerável desenvoltura sobre os assuntos que surgiram. Demonstraram desse modo estarem ávidos por um espaço de escuta e também de expressão.

Inicialmente expuseram questões de âmbito geral, referentes à profissão e à categoria como um todo. Ao longo do encontro porém, trazem expectativas e experiências pessoais e os sentimentos suscitados por elas. Os integrantes conseguem expressar não só opiniões como também alguns sentimentos envolvidos.

Sobre os temas expostos ficam evidentes algumas contradições nas relações e sentimentos vividos pelos alunos. Os alunos de medicina "podem" e os da enfermagem não; os profissionais que atuam e o profissional que deseja ser; ser profissional e ser humano; acreditar na 
própria competência e provar a própria competência; cuidar de si e cuidar do outro; união/cooperação e desunião/competitividade.

A apresentação das respostas das entrevistas ( $1^{\text {a }}$ momento) em forma de esquema e ilustradas com a leitura das falas pertinentes foram facilitadoras para o tema disparador.

Estava preocupada com a adesão dos alunos em relação à participação do grupo, pois sabia que a maioria desenvolvia outras atividades, e surpreendi-me com a presença e espontaneidade de todos.

Confesso que inicialmente estava ansiosa e também constatei que muitas das questões e sentimentos vividos pelos alunos em algum momento eu os havia experimentado, mas percebi que, como coordenadora, pude tomar o distanciamento de mim mesma para poder realizar uma escuta e intervenções adequadas.

\subsubsection{Segundo Encontro}

\section{Devolutiva das entrevistas individuais $-22 / 08 / 2005$}

A segunda sessão aconteceu no mesmo local, no Anfiteatro do Hospital Santa Lucinda.

Iniciei a sessão às 15:30 horas, agradecendo a presença de todos os colaboradores, os mesmos doze que haviam participado da 
primeiro encontro: Fred, Giseli, Paola, Rosa, Lua, Sol, Ana, Flor, Brenda, Mel e Henrique. Contei também com a presença da observadora.

Recordei que a cada encontro abordaríamos as respostas de cada questão formulada nas entrevistas individuais.

Passei então a projetar os resultados das respostas da segunda questão em forma de esquema.

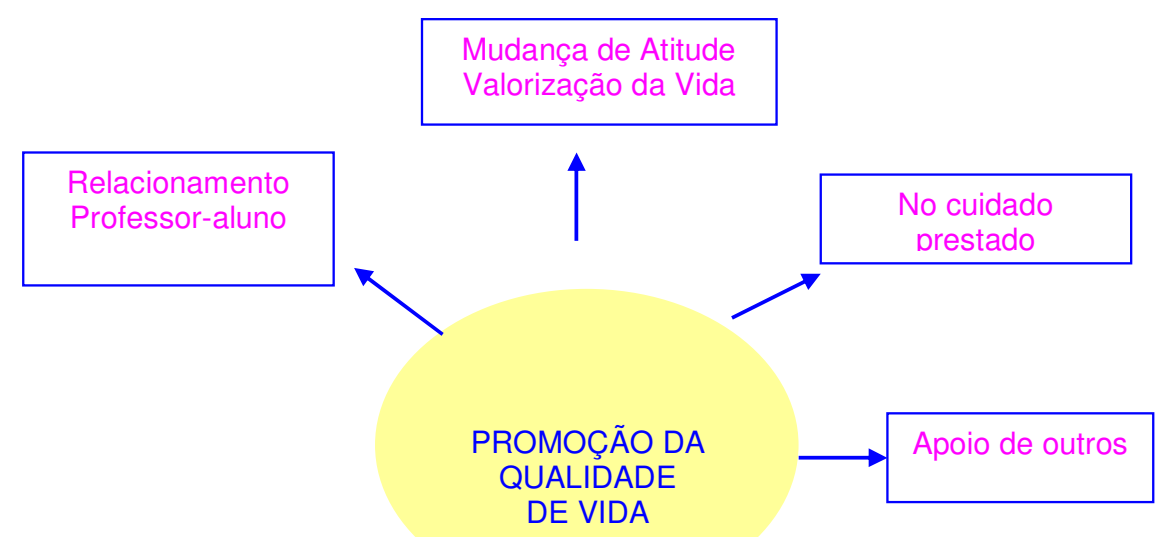

Cidadania /Conquista dos Direitos e consciência dos Deveres
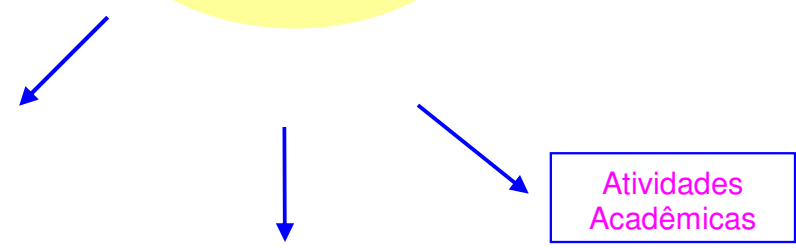

Aulas de Psiquiatria,

Psicologia e

Antropologia

Foram relatados por mim depoimentos dos alunos que ilustravam essas categorias encontradas. 
Após a apresentação dos relatos do tema, perguntei ao grupo: "O que vocês pensam sobre essas coisas que vocês viram? Tentem relacionar um pouco com o que vocês vivem".

Segue-se um momento de silêncio e então o grupo começa a trazer questões relacionadas, as disciplinas que em sua opinião foram importantes para a formação tanto pessoal como profissional, a instituição de ensino.

Flor valoriza o fato do curso oferecer disciplinas (Ética, Antropologia e Psiquiatria ) que possibilitam a reflexão e a crítica. "...se você não tem uma vida de reflexão e crítica, a faculdade puxa...se você não tem essa vida de reflexão...a PUC te chacoalha um pouco..." Essas matérias, com certeza, fazem a gente pensar na qualidade de vida”.

Lua acrescenta: "Essas aulas trazem muito à tona a questão dos valores, o que você traz, de onde você vem e até onde você quer chegar, e reflete no dia a dia de todo mundo."

Rosa relata uma situação conflituosa vivida nesta semana pela sua turma e a importância do acolhimento realizado pela professora de psicologia.

"Estavam todos muito nervosos com problemas com outro professor. A professora de psicologia falou que não conseguia dar aula, não posso continuar se vocês não se acalmarem. Tinha gente até chorando. Ela sentou como uma mãe para gente e deu o maior 
apoio. Foi uma promoção de qualidade de vida para gente. Ela fez a gente parar para pensar, ensinou os caminhos".

Flor menciona também o bom relacionamento professor/aluno do atual contexto de ensino: “...até a mãe de uma aluna chegou e falou que o nosso relacionamento com os professores, tem que levantar as mãos para o céu ...você pode chegar e conversar com o professor na boa".

Em seguida, é notada por Henrique a semelhança existente entre as respostas e questões levantadas pelos alunos entrevistados na pesquisa e o que vivenciam atualmente. "São temas atuais...É legal, tem uma constância... e isso vinha de várias turmas...”.

Segue relacionando uma constância com o modelo do Centro Acadêmico da Enfermagem (CAE), segundo ele, o modelo de CA não funciona mais e é necessário atualizar, encontrar um modelo que seja mais próximo da realidade dos alunos de enfermagem que mudaram muito.

Flor concorda e diz: “... eram mais velhos, já tinham filhos”.

Rosa: “... o curso não é mais integral, a maioria também não trabalha".

Rosa vê a sua turma ávida por conhecimento e sem interesse em participar em festas, mesmo as de Confraternização: “Eu vejo que na minha classe querem muitos cursos, palestras... No final do semestre 
fizemos uma confraternização só com o pessoal da minha classe, só foram oito pessoas".

Em seguida, os alunos enumeram algumas situações compreendidas por eles como promotora da qualidade de vida durante 0 período de formação.

Sol identifica alguns estágios como tendo um papel relevante para a formação e para a noção de qualidade de vida: "Hoje, no estágio de Psiquiatria, fomos conhecer os lares abrigados que surgiram após a desospitalização. Foi muito interessante porque a casa deles tem um aspecto de casa...o quarto das pacientes me chamou muito a atenção, uma delas faz desenhos maravilhosos.... a qualidade de vida deles melhorou muito porque eles estão sendo inseridos na sociedade novamente, de uma forma digna, com cidadania...estágio veio muito a contribuir como ser e como profissional".

O fato também de entrar na faculdade e todo o contexto de mudanças que isto envolve na vida do aluno, é percebido como promotor da qualidade de vida à medida que o aluno vai conquistando a sua identidade. Isto fica bem evidenciado quando Paola diz:

“Para mim, só o fato de entrar na faculdade, mudou muito a minha qualidade de vida. Mudou o meu relacionamento aluno/professor, conhecer vários amigos, as atividades acadêmicas, morar sozinha, ter 
mais dever e mais consciência. Eu mudei bastante $o$ meu jeito de pensar".

Fred complementa dizendo da liberdade que se conquista com essas mudanças:“ Mais liberdade”. Paola enfatiza: "A liberdade, com dever e responsabilidade".

O atendimento oferecido pelos funcionários da escola é anunciado por Rosa como promotor da qualidade de vida: “ $A$ gente não pode esquecer dos funcionários, da biblioteca, da secretaria, eles se preocupam com tudo que acontece com a gente; no SETAL ${ }^{6}$, tem pessoas muito legais, preocupam-se com os alunos como seres humanos. Elas dão muito apoio para gente".

O cuidado prestado aos clientes pelos alunos traz uma sensação de satisfação, sentem-se úteis, por outro lado, projetam para o futuro profissional a preocupação em dar continuidade a este tipo de assistência. Flor afirma: “...quanto ao cuidado prestado, você faz a coisa certa, você prescreve aqueles cuidados que vão contribuir para a melhora do paciente, a gente fica com aquela sensação de missão cumprida. Será que vai ser assim todo dia quando eu trabalhar? Tem que fazer a diferença todo dia, fazer o melhor, fazer o melhor para ele e consequentemente para mim; com certeza a gente se sente bem com o nosso serviço...".

\footnotetext{
${ }^{6}$ SETAL - Secretaria do alunado
} 
Paola expressa neste momento o quanto se sente mal quando não consegue realizar uma tarefa com sucesso:“ ... uma veia que eu não consigo pegar, fico mal o resto do dia...já acabou para mim".

Em seguida lembro ao grupo a proposta que eu havia feito no encontro anterior, de mergulhar (usando a metáfora da piscina) dentro de si e buscar algo de bom. Peço então que fechem os olhos e busquem resgatar algo importante que vivenciaram durante esses anos de formação. Em seguida vamos compartilhar com o grupo.

Então, o grupo começa a trazer suas experiências consideradas de sucesso ou de coragem em que aparecem entre outras coisas a escolha profissional, o papel do professor como orientador e também o compromisso com a própria formação.

Sol se refere ao seu mergulho de uma forma generalizada, associada às barreiras que teve que romper: "O meu mergulho na piscina foi uma forma de romper as barreiras que foram impostas por todos, romper todos os obstáculos...”.

Paola conta que: “ ...foi a partir deste ano,... fez-me acordar mais, me empenhar, eu gostava do curso, mas era muito imatura, foi por causa da professora de Administração...foi a partir daí que eu dei o meu mergulho".

Ana considera que deu seu mergulho quando tirou o objetivo de mudar de faculdade: " ... eu entrei no primeiro ano, eu não queria fazer 
aqui,... queria muito mudar de faculdade...neste ano comecei a me dedicar mais à PUC,... consegui ser monitora e me integrar mais na Faculdade...hoje sou representante da Comissão de Série, eu aprendi a gostar...”.

Henrique atribui seu mergulho à escolha profissional em si: “ ... eu tinha o plano de fazer enfermagem, faz tempo. Você escolher algo que gosta e saber que você pode estar sempre melhorando...".

Sol conta sua história dizendo que sempre quis fazer enfermagem e o quanto foi difícil para entrar, fez reopção do curso de biologia para enfermagem: “...dei o meu nome, mas não esperava...quando saiu o resultado...eu pulava de tanta alegria... é a profissão que eu vou me dedicar e fico muito feliz de ter conseguido".

Lua diz que: “...a gente sempre acaba mergulhando quando a gente acaba sendo reconhecido, ... isso nós faz mergulhar em várias situações que acontecem com todo mundo, até prova mesmo, ... no estágio sempre acontece, quando conseguimos atingir nossos objetivos...”.

Flor considera seu mergulho quando concluir seu trabalho de Iniciação Científica: “ O dia que eu entregar meu relatório de Iniciação Científica eu vou mergulhar, vou me afogar, risos. É uma coisa que eu encarei como desafio, uma coisa que eu queria e quero muito...”. 
Rosa lembra da participação dos alunos no Projeto Nefroriso4: "A gente não pode esquecer do "Nefroriso" que é uma coisa que ajuda muito a gente. $O$ ano passado me fez muito bem, eu entrei na última semana e foi maravilhoso. Tinha que ter uma vez por mês algo parecido com isto"!

Fred diz: "Eu ainda estou no fundo da piscina...foi perseverança e garra para esta aqui ( cursando a faculdade) até hoje”.

Gisele associa o seu mergulho ao fato de estar indo melhor no curso: "Eu nunca quis fazer enfermagem, aí, eu passei. Até o segundo ano eu não gostava e agora, neste ano eu me achei mais e estou indo melhor".

Após um longo período de silêncio, pergunto ao grupo como eles pensaram neste mergulho? Foi fácil ou difícil para vocês?

Seguem-se falas breves e em que dizem não terem encontrado dificuldades em realizar o exercício proposto anteriormente.

Em seguida, recoloco a pergunta:“ $\boldsymbol{A}$ maioria achou fácil...vamos pensar agora qual o sentimento quando fizeram 0 exercício".

Alguns alunos trouxeram sentimentos de forma sucinta como:

7. Atividade extra-curricular organizada e desenvolvida pelos alunos. Tem como objetivo propiciar momentos de descontração e alegria à pacientes e funcionários da Unidade de Hemodiálise. 
Fred: "Satisfação que você está conseguindo, orgulho".

Sol: "Alegria e felicidade".

Henrique: "Conquista”.

Paola: "Capacidade".

Rosa: "Insegurança, mas, ao mesmo tempo, alegria".

Mel: "Confiança também, mas ainda estou no processo".

Brenda: "Um sentimento de bem estar".

Após um breve silêncio faço os seguintes comentários: “...o ato de mergulhar é um ato solitário, por mais que tenha alguém...é um ato solitário...e exige muita coragem, não é fácil...Somos nós mesmos que fazemos as escolhas. As escolhas são de cada um e somos responsáveis por essas escolhas. Como é isso para vocês?

Em seguida a minha pergunta o grupo se coloca, ora citando alguns processos de "culpabilização" do outro, ora ressaltando a condição de solidão/individualidade do ser humano.

Rosa diz: " A gente é muito acostumado, a colocar a culpa no outro".

Henrique complementa: “... você é vítima do sistema, do professor...".

Sol fala: “...é um mecanismo de defesa, projeção...”. 
Henrique comenta agora: “...a gente sempre será sozinho”.

Lua concorda: " A gente vem sozinho e vai sozinho. Não tem jeito".

Já próximo do final do encontro Henrique pergunta aos demais se sentem-se sós e então são relatadas experiências de solidão diferentes entre si.

Ana: "Sempre fui fechada para tudo e para todos ... quando vim para cá senti uma solidão ... eu cresci muito ... eu encontrei pessoas muito boas aqui em Sorocaba".

Fred: “... você começa a pensar em você mesmo ... você mergulha em você ... às vezes é bom".

Encerrei o encontro às 17 horas. Agradeci a presença de todos e confirmei a data e local do próximo encontro.

\section{Minhas impressões}

Em relação ao primeiro encontro, houve muitos momentos de silêncio, porém quando se colocavam o faziam de maneira clara. Alguns integrantes ainda estão participando pouco das discussões.

Nesse encontro são tratados muitos assuntos diferentes, porém, um dos que pareceu mais relevante para o grupo, foi o resgate de experiências consideradas de sucesso, de competência ou de autosuperação e a possibilidade de compartilhá-las. Entre as questões pessoais 
relacionadas ao contexto de formação puderam compartilhar e discutir a respeito da motivação de cada um com relação à carreira e à própria profissão.

Minha intenção foi de oportunizar um espaço para resgatar um pouco as potencialidades de cada um e o seu protagonismo. Acredito que a proposta foi correspondida.

O grupo pode refletir e pontuar sobre situações promotoras de qualidade de vida durante a formação.

Percebi que os períodos de silêncio significavam um tempo para o contato com o mundo interno de cada um e a reflexão. Trata-se de uma vivência pouco exercitada pelos alunos durante a formação.

\subsubsection{Terceiro Encontro}

\section{Devolutiva das entrevistas individuais $-03 / 09 / 2005$}

Agradecendo os presentes: Giseli, Paola, Lua, Ana, Brenda, Mel e Henrique e comunicando a ausência de Fred, Rosa e Sol e suas justificativas enviadas, iniciei o encontro no mesmo horário e local previstos. Flor chegou após o início do grupo, justificando o seu atraso. Participou a partir das apresentações das dramatizações. Como programado, contei com a presença da observadora. 
Resgatei a estratégia de trabalho inicial do grupo e iniciei abordando a resposta da $3^{\mathrm{a}}$ questão formulada nas entrevistas individuais. $\mathrm{O}$ esquema 3 mostra situações percebidas como não promotoras de qualidade de vida, citados pelos colaboradores.

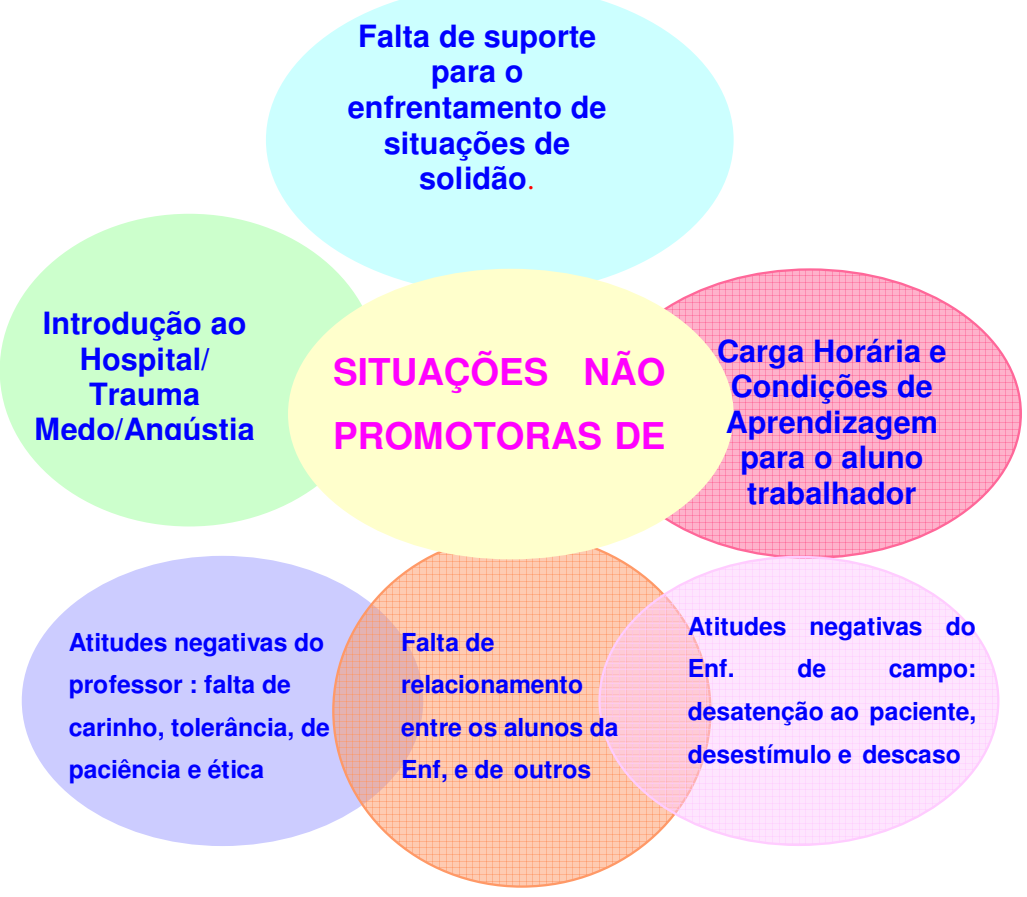

Após explicar o esquema, relatei os depoimentos dos alunos que ilustravam essas categorias encontradas.

Em seguida solicitei que os integrantes se dividissem em dois grupos a fim de elaborar e apresentar uma dramatização de uma situação considerada por eles como não promotora da qualidade de vida vivida no contexto acadêmico. 
Os grupos foram formados por representantes das diferentes séries e após elaboração, iniciamos a apresentação descrita a seguir:

Grupo 1: Formado pelos alunos - Henrique, Gisele e Brenda. Dramatizam uma situação vivida em sala de aula. Henrique vivência o papel do professor, Gisele e Brenda, as alunas.

O professor de Bioquímica gesticula e escreve rapidamente (copiando de suas anotações) na lousa o Ciclo de Krebs. Uma das alunas pergunta ao professor: "Professor, precisa decorar tudo isto?" O professor permanece em silêncio. As alunas entreolham-se, a outra aluna repete a pergunta da colega. "Professor, precisa decorar tudo isto?" O professor, então, vira-se e impõe-se dizendo: Como??? Tem que saber ou vai querer ser uma auxiliar de enfermagem? A aluna de forma provocativa diz; "Como se o senhor não sabe! Ou você sabe ou não."

O grupo encerra a dramatização, todos riem e aplaudem.

Grupo 2: Ana, Paola, Lua e Mel. Apresentam uma situação vivida no estágio prático na sala de parto. Ana vivencia o papel da aluna, Paola a professora, Lua a enfermeira e Mel a parturiente.

A parturiente está prestes a dar à luz, agitada, não consegue fazer força. A aluna a acolhe, procurando acalmá-la e solicita que a mesma preste atenção na respiração e tente fazer força. A aluna é surpreendida pela enfermeira que a empurra e assume o seu lugar forçando a parturiente a fletir o tórax para fazer força. A aluna, chateada, espera por um 
posicionamento da professora que se mantém em silêncio, sem nenhuma expressão.

A dramatização é encerrada pelo grupo e todos aplaudem

Em seguida, solicito que comentem sobre as dramatizações realizadas.

Logo em seguida, Lua já comenta sobre a segunda dramatização: “... as quatro falaram de situações que passaram e de sempre conviver com o não-exemplo ...". Mel acrescenta a sua opinião; “... na teoria é uma coisa, na prática é outra."

Henrique menciona como encarou a encenação e comenta que foi uma situação vivida por ele: “...senti, provoquei também o professor, porque, o professor vai ensinar, como ele vai passar que é importante uma coisa que ele ensina e não sabe os passos mais importantes?" Declara que:

“ Na verdade eu o cutuquei...o interessante é que logo ele se referiu ao auxiliarão de enfermagem, o enfermeiro sabe alguma coisa mais complexa ou então vira auxiliar de enfermagem."..."Eu pensei ainda: tem auxiliar de enfermagem que pode saber muito mais do Ciclo de Krebs do que ele."

Após um breve silêncio pergunto: "Como foi para vocês fazerem essa dramatização?"

Algumas pessoas mencionaram como haviam encarado as encenações e logo o grupo passa a citar situações de desconforto vividas durante os estágios e associadas à figura do professor/supervisor: Em 
relação às dramatizações, Paola diz que: "Difícil." Henrique refere que: "Para mim não foi difícil ... foi uma situação que eu vivi ... provoquei, por isso que não foi difícil. Você provoca o professor para ver o quanto ele sabe, é diferente de uma situação como a do segundo grupo, que foi vivida na prática."

Referindo-se a situações de desconforto vividas durante os estágios, Henrique conta que quando vai atender uma mulher a professora chega dizendo: "Homem para fora!" Diz Henrique: "Ridículo." Então já fala no começo que este curso de Enfermagem é só para as mulheres e não entram homens."

Mel comenta: “... não sei se com o médico acontece isto?”

Brenda lembra que: "Também tem mulheres que só vão com mulher. Tem que ter esta opção." Henrique sustenta a idéia de que se perguntar à mulher se ela quer ser atendida por homem aí então ela pode achar que há outras intenções.

Lua interfere sugerindo uma saída para a situação: “...o professor deve apresentar o grupo todo como alunos e deixar em aberto para as pacientes...”.

O assunto é encerrado por Henrique que diz: "Dependendo da situação é o próprio professor que cria o mal estar."

Pergunto ao grupo: “Quem fez o papel e quem assistiu. Como é que foi fazer, como é que foi assistir?" 
Gisele, comenta: "Vocês passaram muito bem, é o que acontece na realidade."

O grupo novamente aponta a figura do professor como de relevância para a qualidade de vida. Flor fala que : “... o que será que eles vão falar quando virem uma coisa que marca mesmo... a postura do professor em relação ao aluno, o professor é o grande promotor da qualidade de vida, e como na faculdade marca muito."

Lua fala do exemplo que é o professor: “...porque a gente como aluno, a gente tem o professor como exemplo, quando a gente vê que o espelho não é tão exemplar. Cada pessoa é uma. Na prática, são raros os professores que são bons exemplos e aí a gente fica se perguntando: Onde estou? O que eu estou fazendo aqui?"

Henrique, falando de quando encontram um professor que gosta de dar aulas diz de como se sente: "É legal, quando a gente encontra um professor que se dedica, que faz o diferencial, parece que está começando a faculdade naquele momento."

Após um silêncio, Henrique continua fazendo comentários sobre a postura do professor: "Ainda assim, a faculdade, eu acho, tem mudado, mas certos professores não estão acostumados com aluno crítico, o aluno que faz a diferença, que critica, faz colocações ou reclama da situação..." 
Retomo a intervenção anterior e após um período de silêncio seguido de algumas falas paralelas o grupo relata uma série de acontecimentos em que se sentiram desvalorizados, humilhados e sem 0 reconhecimento de seu papel por parte do professor e da enfermeira de campo.

Ana retoma a situação dramatizada e vivida por ela na prática e desabafa: “... ela me empurrou, a professora viu e não falou nada ... você se sente: o que eu estou fazendo aqui? ... ela fez tudo certinho e nós alunos sempre por baixo ..."

Gisele compartilha da fala de Ana e comenta: "Aconteceu com a gente, a enfermeira falou que a gente só atrapalha, só que a gente faz tudo lá, disse que a gente só ri, conversa e não faz nada."

Ana lembra e diz: “... todas as enfermeiras que estão ali se formaram aqui, até os professores, a gente se sente inútil nessas horas".

O silêncio que segue é quebrado pela fala de Paola:“... o professor cobra muito do aluno e quando você faz uma pergunta, ele vira com uma coisa que vai te machucar e não dá nem para você responder, ele trata mal o aluno, na frente de todo mundo..." Flor concorda e fala: “... o professor parece que se sente uma pessoa superior...quando a gente pressiona o conhecimento dele, parece que ele vai se rebaixar." Comenta sobre como acontece o ensino aprendizagem na infância: “... a gente foi criado desde pequenininho num sistema de perguntas e respostas." 
Paola retoma a relação professor - aluno na aprendizagem: “... você pergunta uma coisa e o professor expõe muito você na sala de aula ..., às vezes você é tímida”. Brenda completa: “... ele ridiculariza ..." "Ri da pergunta da gente e não explica."

Neste momento comento e pergunto: "Vocês trouxeram várias situações... muito voltadas à parte de postura do professor... Vocês podem pensar em outras situações que percebam como não promotoras da qualidade de vida?"

O grupo fala do pouco conhecimento da profissão no âmbito familiar e também no acadêmico, bem como da necessidade de em diversos momentos ter que diferenciar o papel do profissional de enfermagem do de outros profissionais da saúde. Relacionada a isso; mencionam também a questão da valorização profissional.

Brenda conta a dificuldade da sua família entender quem é o enfermeiro: “ ... primeiro vem a auxiliar, a enfermeira ... Não tem quem é mais e quem é menos, enfermagem é uma profissão igual à fisioterapia, fonoaudiologia, psicologia." Outros alunos concordam. Paola conta que:"...em casa foi muito difícil também ..."

Em seguida pergunto: "Como vocês vêem essa situação interferindo na qualidade de vida de vocês ?"

São citados mais alguns exemplos do que vinha sendo dito a respeito do pouco conhecimento sobre o que realizam enquanto alunos: 
Gisele ri e diz: "Tem uma amiga da nossa classe que o pai dela diz que ela faz faculdade de auxiliar de enfermagem". Paola comenta: “...tem um pouco de rejeição, preconceito." Henrique conta que: “... quando vou ao trabalho mais relaxado, as pessoas não têm dúvida: auxiliar de enfermagem, e eu vou vestido mais socialmente, embora eu ainda seja auxiliar de enfermagem, me chamam de enfermeiro."

Respondendo ainda a questão, também é dito sobre o contato limitado entre os cursos de áreas correlatas dentro da faculdade: Henrique comenta: "Outra situação que foi citada na apresentação ... é criar ... interação entre cursos, mas a faculdade não tem nada que cria esta interação com os cursos ..., não tem nada, vamos dizer se você tivesse um momento para discutir alguma coisa”. Flor acrescenta: “... parece que só usa o mesmo prédio.” Henrique, em seguida, sugere: “... seria interessante discutir na faculdade um dispositivo da faculdade para promover esses encontros. Talvez muitas coisas aí se desmistificassem. É uma situação não vivida a criação desta oportunidade."

Pouco antes do término do encontro, solicito que cada um relembre uma situação que viveu e que considera não promotora da qualidade de vida. A partir daí, citem 3 sentimentos suscitados por essa experiência: "Vão tentar perceber o que aquela situação trouxe para vocês ... de sentimentos ... Vamos pensar?"

Logo após a minha intervenção, Lua pede para falar e diz: “ $A$ primeira sensação que dá é mágoa, impotência e ao mesmo tempo garra." 
Flor; "Sinto uma sensação horrível de mãos atadas e muita insegurança quanto ao futuro." Paola comenta: "Tristeza, raiva e arrependimento." Sol concorda com ela. Gisele, enfaticamente fala: "Muita, muita e muita raiva mesmo." Brenda comenta: "Insegurança, incompreensão e chateada." Mel : "Insegurança, incapacidade e tristeza." Henrique, pensativo, diz: "Desvalorização e tristeza." Ana, desabafa: "Tristeza, impotência e inutilidade...quando eu me formar vou ser bem melhor que ela."

Em seguida, encerro o encontro, lembrando que na próxima semana será o nosso penúltimo encontro.

\section{Minhas impressões}

A cada encontro percebo mais o comprometimento dos alunos em participar, chama a atenção a preocupação em avisar e justificar as ausências. Em relação ao primeiro e segundo encontros, houve uma comunicação mais distribuída entre os participantes.

A estratégia da dinâmica foi muito bem respondida pelos participantes e permitiu uma aproximação maior com o tema e os sentimentos envolvidos.

Ao considerar o aprendizado, puderam compartilhar diversas situações em que se sentiram desqualificados ou desmerecidos e que contribuíram negativamente para sua qualidade de vida no contexto acadêmico. Exploraram predominantemente situações em que, segundo 
eles, o comprometimento da qualidade de vida esteve relacionado à figura do professor/supervisor.

Confesso que estas situações incomodaram-me muito e que foi difícil lidar com elas, pois, remete-me a situações minhas vividas como aluna e faz-me questionar o meu papel atual como professora. Como coordenadora do grupo exercitei o meu distanciamento para permitir uma escuta adequada e intervenções acertivas.

Os participantes mostraram-se muito à vontade ao relatar suas experiências, mas, não conseguiram problematizar as situações consideradas não promotoras de qualidade de vida, atendo-se a mencionar diversos exemplos, sem refletir sobre as implicações de tais situações/exemplos na qualidade de vida dos alunos.

Acredito esta situação ser reflexo do modelo que os alunos vivem no contexto de aprendizado, onde as oportunidades para refletir são poucas ou até inexistentes.

Foram possíveis perceber algumas contradições vividas pelos alunos como: exemplo e não exemplo, dicotomia entre teoria e prática, manifestar as dúvidas para o professor e não manifestar as dúvidas, falar e calar, perguntar e responder, ser mais valorizado e ser menos valorizado.

O grupo deixa claro algumas contradições em relação à reflexão e alienação; maior envolvimento com o curso e menor envolvimento com o curso; crescer na relação e crescer na solidão. 


\subsubsection{Quarto Encontro}

Construindo a qualidade de vida durante a formação $10 / 09 / 2005$

O quarto encontro aconteceu no mesmo local, no Anfiteatro do Hospital Santa Lucinda.

Iniciei a sessão às 15:30 horas, agradecendo a presença de todos os colaboradores: Fred, Giseli, Paola, Rosa, Lua, Sol, Ana, Flor, Brenda, Mel. Registrei a ausência de Henrique. Contei também com a presença da observadora.

Os alunos estavam bem integrados, conversavam entre si. Ficaram curiosos ao verem o aparelho de som sobre a mesa.

Solicito a atenção e peço para que cada um identifique em suas experiências acadêmicas (âmbito hospitalar, aulas teóricas, relação com os colegas e etc...) uma situação potencializadora ou seja, uma situação em que reconhecem uma potencialidade própria.

Após um silêncio reflexivo, os participantes passam a citar diversas situações consideradas vitoriosas e em que se reconheceram capazes e/ou se sentiram valorizados.

Sol diz que : “...foi o meu projeto de iniciação científica, com certeza..." 
Flor fala da importância de sentir-se reconhecida pelo outro “... a pessoa reconheceu, o familiar reconheceu ...é uma coisa que você aprendeu, aplicou e deu certo ..."

Rosa traz uma situação bem próxima; “... eu tenho dificuldade de apresentar trabalho (relatou um episódio em que conseguiu apresentar com êxito um trabalho) ela (professora da disciplina) me elogiou ...fiquei super feliz, percebi que eu consigo ...recebi muitos elogios do professor..."

Paola fala da sua insistência no enfrentamento das dificuldades: “... enfrentei barreiras e não desisti em permanecer no mesmo curso."

Ana conta que: "Eu acho que foi a minha monitoria em parasitologia, me ajudou muito e recebi muitos elogios do professor...não sabia que era tão importante aqui...cada dia que passa sinto-me mais importante ali."

Brenda e Mel compartilham as suas potencialidades ao ajudarem o outro. Brenda diz: “...estou ajudando as pessoas, meus amigos, meus familiares, meu pai e isto também me ajuda.” Mel fala que: “... quando vou na prática, apesar do meu medo, você está lá diante de uma pessoa, ...depois você vê que fez a coisa certa... é uma vitória.”

Gisele fala do seu amadurecimento; “...amadureci bastante, quando eu estava no primeiro ano, a professora me chamou e disse que eu 
não levava jeito, que eu era muito medrosa. Agora eu me apego muito ao paciente, coisa que ela falava que eu era distante deles."

Sol relata que: "...minha experiência de dois anos no ambulatório...me senti e sinto hoje muito importante em prestar uma assistência adequada, diferenciada.”

\section{Pergunto ao grupo: "Como foi para vocês pensarem} nessa situação... ? como vocês se sentiram ... ?"

Alguns alunos mencionaram 0 contentamento experimentado: Flor verbaliza "foi legal... passa esperança". Gisele fala: "a gente ficou orgulhoso".

Em seguida, proponho que escutem uma música que havia sido preparada e vejam o que tem a ver com o que falaram e trouxeram hoje para o grupo.

Os participantes ficam em silêncio e a música começa a fluir:

\section{Tente Outra Vez}

Raul Seixas

\section{"Veja}

Não diga que a canção está perdida

Tenha fé em Deus, tenha fé na vida

Tente outra vez

Beba (Beba)

Pois a água viva ainda tá na fonte

Você tem dois pés para cruzar a ponte

Nada acabou, não, não, não 
Tente

Levante a sua mão sedenta e recomece a andar

Não pense que a cabeça agüenta se você parar

Não, não, não, não, não, não

Há uma voz que canta, há uma voz que dança

Há uma voz que gira

Bailando no ar

Queira (Queira)

Basta ser sincero e desejar profundo

Você será capaz de sacudir o mundo

Vai, tente outra vez

Tente (Tente)

E não diga que a vitória está perdida

Se é de batalhas que se vive a vida

Tente outra vez"

Após a execução da música os participantes falaram a respeito do que achavam que a canção pretendia comunicar.

Paola fala empolgada: “...tem tudo haver comigo, e eu não tentei uma vez, eu tentei duas, três, acho que eu tentei bastante, mas era o que eu queria."

"Mel diz: "ser perseverante." Fred completa: "através dos problemas e dificuldades a gente também aprende." Gisele: "Não é porque surgiu um obstáculo que a gente vai desistir.”

Flor emocionada fala: “...a vida inteira a gente vai ter questões pela frente."

Sol diz que o que chama a sua atenção é a fé em Deus: “...a fé em Deus, não importa a religião, você tem que buscar um apoio, aquela 
esperança, aquela força para trabalhar, aprender...ter fé em Deus que vai melhorar."

Paola fala da sua dificuldade em prosseguir quando perdeu pela primeira vez e depois pela segunda vez: “...coloquei na minha cabeça que eu ia vencer...sentia-me fraca, boba, não sabia a força que eu tinha dentro de mim..."

A partir da fala de um integrante faço uma nova intervenção: "A Paola falou que ela não percebia a força que ia dentro dela ... Como é que vocês percebem essa força dentro de vocês ? Ela existe ? Que tamanho é essa força?

Segue-se uma longa fala de uma integrante que credita sua força ao apoio familiar e ao desejo de poder retribuir esse apoio e ao final menciona suas expectativas com relação ao próprio desempenho profissional: "Eu não quero estar num hospital só por enfeite ... eu quero refletir para o paciente uma diferença, ... Quero prestar uma assistência de qualidade que é o que eu busquei aprender ..." (Sol).

Em seguida, a pedido de outro integrante a coordenadora repete e esclarece a intervenção anterior: “... vocês têm essa força ... com é que está? ... de onde vem? ... como vocês alimentam essa força?"

Em algumas falas que se seguiram, houve o reconhecimento de que a força está no interior de cada um e que por vezes ela é descoberta 
ou estimulada na relação com o outro: Rosa fala: “... eu nunca me lembro da minha força, eu me lembro de uma frase do meu pai dizendo que eu não iria conseguir fazer a faculdade, ele lançou um desafio para mim e a força vem desse desafio".

Lua comenta que : "...tudo que a gente faz na vida...em primeiro lugar é pela gente mesma... a força está dentro e você tem que cuidar dela ..., depende muito da gente, é querer e saber o que a gente quer..."

Ana completa: "A minha força eu sinto que fui obrigada a achar ... ele (o pai) me ensinou a buscar essa força dentro de mim ..."

Após mais algumas falas exemplificando o assunto que estava sendo trazido peço que se dividam em subgrupos e cada um escolha uma maneira de representar como percebem a construção da qualidade de vida e como é que pode ser construída essa qualidade de vida durante a formação.

São formados 3 subgrupos e após o tempo determinado para elaboração, iniciamos as apresentações. Cabe observar que durante a elaboração os alunos participaram de forma ativa.

Grupo 1 Formado pelos seguintes participantes: Gisele, Fred, Sol e Brenda. 
Sol inicia a apresentação explicando que o grupo optou em elencar palavras e que cada um foi contribuindo com suas idéias e construíram o seguinte quadro:

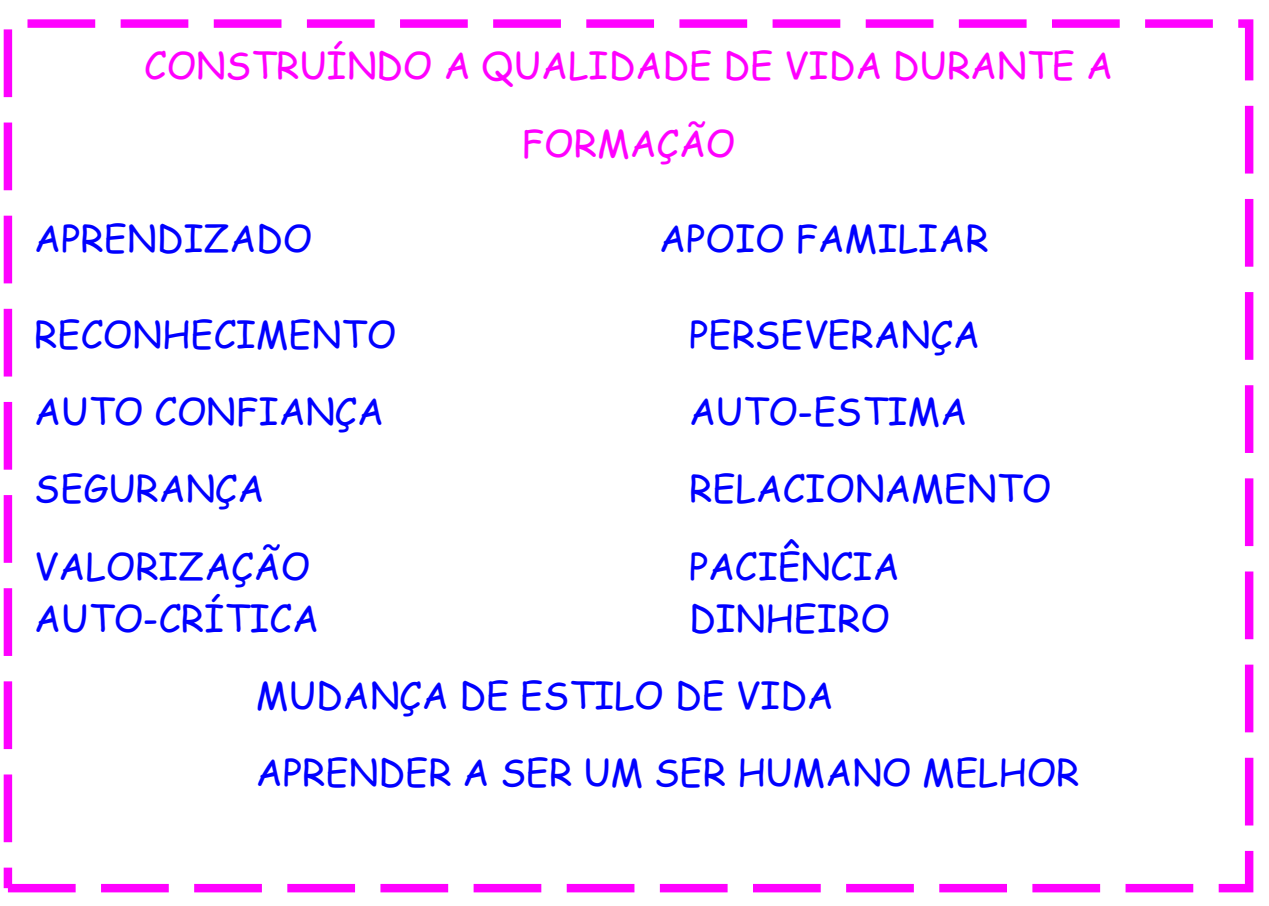

Solicito que expliquem o que entendem por mudança de estilo de vida.

Sol responde: “Um exemplo é a nossa alimentação antes e depois da faculdade... você muda seu estilo de vida...adquire conhecimento."

Pergunto sobre o que querem dizer ao relacionar a paciência e Brenda explica que está relacionada com os outros, e consigo mesmo. 
Em relação aos demais itens, Fred fala: "O reconhecimento está relacionado a sermos reconhecidos pelas outras pessoas, da faculdade, da família..."

O conhecimento, embasado, segundo Brenda, e Fred é o que de alguma forma vai melhorar a auto estima e a qualidade de vida.

O relacionamento é entendido na fala de Gisele como: "Relacionamento com professores, pacientes, pais...tem que ser bom."

O dinheiro, diz Fred: "É com o dinheiro que você vai ter uma segurança maior para continuar os estudos." Brenda acrescenta concluindo a apresentação: "A gente pensa muito nisso".

Grupo 2 Constituído pelas seguintes participantes: Paola, Lua e Rosa.

Lua inicia explicando que colocaram uma somatória de várias coisas, sentimento, sonhos e que tem muita coisa envolvida.

Construíram o seguinte quadro.

$$
\begin{aligned}
& \frac{\text { CONSTRUÍNDO A QUALIDADE DE VIDA DURANTE A }}{\underline{\text { FORMACÃOO }}} \\
& \text { SONHO + CONQUISTA+ AMIZADE+ APOIO+ RESPEITO+ } \\
& \text { CONHECIMENTO+ LAZER+ BOA ALIMENTAÇÃO+ } \\
& \text { RELACIONAMENTOS SAUDÁVEIS+ PERSISTENNCIA+ } \\
& \text { FAZER O QUE GOSTA = QUALIDADE DE VIDA. }
\end{aligned}
$$


Rosa aponta para o quadro e fala sobre o sonho de fazer faculdade, novas amizades e do crescimento que isto proporciona como pessoa.

Paola considera o amor o principal apoio: "Todo mundo tem que ser bem amado...o relacionamento deve ser com amor."

Lua aponta para o conhecimento e explica: "Com o tempo o conhecimento também vai pesando, você vê muita coisa que vai passando e tem que correr atrás. Você vê alguma coisa que errou e volta para traz para ver onde foi que errou." Rosa acrescenta: "Você, tendo conhecimento, tem mais segurança."

Paola enfatiza: "Tem o lazer ...o afeto." Lua completa: “...você pode trabalhar em vários lugares, mas, precisa ter um tempo para o lazer..."

Falando sobre a boa alimentação, Rosa declara: “... por mais que a gente saiba.. e como estudante a gente come mal, só porcaria!"

Lua encerra a apresentação do grupo fazendo referência sobre os relacionamentos saudáveis com familiares, funcionários.

Grupo3 Participantes: Ana, Flor e Mel

Ana apresenta o seguinte esquema: 


\section{NÃO É PRECISO APENAS FAZER O QUE GOSTA, MAS SIM, GOSTAR DO QUE FAZ!}

União Igualdade

\section{Força \\ Perseverança}

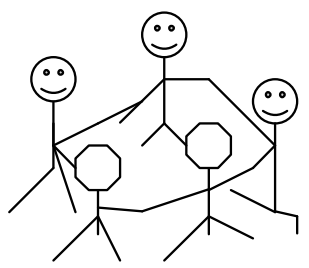

\section{Oportunidade}

Apoio

Integridade

Ana apresenta dizendo que: "o grupo fez um círculo mas que tem que estar todo mundo junto, a integridade, a igualdade, gente de outros países que na faculdade sofrem preconceito...a perseverança para nunca desistir, a força que a gente busca todo dia, o apoio familiar, colegas... a parte espiritual, a gente tem que ter força para batalhar... a união é muito importante, não só a dos colegas, professores e de toda a comunidade que a gente convive os 4 anos, a união é muito importante."

Em relação à frase de apresentação: "Não é preciso apenas fazer o que gosta, mas sim, gostar do que faz”, Flor explica: “... se a gente escolheu de todas as profissões, esta, a gente tem que estar aqui e dar o melhor de nós para aquilo que vamos fazer".

Findas as apresentações, inicio um diálogo com os integrantes de cada subgrupo a fim de esclarecer e explorar pontos contidos e relacionados em cada apresentação. 
No primeiro subgrupo foram destacados: paciência, reconhecimento, aprendizado, relacionamento e etc...

Já no segundo subgrupo: auto-estima, conhecimento, relacionamentos saudáveis.

E no terceiro subgrupo: integridade, igualdade, perseverança, união, fazer o que gosta.

Sinalizando o que havia sido trazido pelos subgrupos e pergunta: “... o que é preciso para ter qualidade de vida. Agora, o que fazer?"

O grupo então menciona a importância da pessoa estar sempre se percebendo, se autoavaliando e reconhecendo quando precisa de ajuda: Flor: “... a gente está sempre refletindo ...”; Sol: "Você vê o que está causando isso ... depois que você identifica, você vai atrás ... a fase mais difícil é identificar ...”; Rosa: “... a gente tem que assumir que a gente não está bem e precisa de ajuda, saber ouvir crítica como crítica construtiva.."

Flor resgata a importância da espiritualidade: "Eu dou muito valor à espiritualidade,...ao autodomínio...bondade, brandura...cultivar cada dia...".

Outro ponto levantado foi a necessidade de extrapolar o comodismo e encarar as mudanças: Flor comenta: “... a gente não pode se acomodar ... acho que há pessoas que não correm atrás de mudanças ...” 
Rosa relata sobre a mudança do professor de anatomia que foi mobilizada pelos alunos da sua turma e o quanto isto a faz feliz em saber que os atuais alunos não estão tendo mais aula com esse professor.

Finalizo o encontro lançando as seguintes questões: "de quem depende a minha qualidade de vida e como é que está minha qualidade de vida?

Lembro aos participantes que na próxima semana será o nosso último encontro.

\section{Minhas impressões:}

Este grupo se destacou pela ampla participação. Os integrantes conseguiram expor e perceber o que estava sendo dito. Em contrapartida, o encontro foi entrecortado por muitos momentos de silêncio.

A estratégia utilizada permitiu que se explorassem as interfaces entre os diversos âmbitos que compõem sua qualidade de vida como o familiar, a historicidade de cada um e suas experiências tanto de vida quanto profissionais.

Os participantes continuam se reconhecendo na fala uns com os outros e também acolhendo os conteúdos trazidos pelo grupo.

O grupo reconhece sua participação articulada aos próprios sentimentos quando relatam momentos que identificam como potencializadores e também quando reconhecem a importância do cuidado 
de si em primeiro lugar: "tudo o que a gente faz na vida ... em primeiro lugar é pela gente ... é uma escolha que a gente faz ... a força está dentro e você tem que cuidar dela ..." ou seja, dão exemplos de como ser protagonista mediante a tarefa (qualidade de vida na formação)

Expressam pensamentos contraditórios como a força que vem de mim e a força que vem do outro, acomodação e mudança, cuidar de si e cuidar do outro e expectativas internas e expectativas externas.

\subsubsection{Quinto Encontro}

O quinto encontro aconteceu no mesmo local e horário dos demais. Estavam presentes: Henrique, Ana, Flor, Mel, Brenda, Lua, Rosa, Gisele e Fred, justificaram as ausências: Sol e Paola.

Iniciei o encontro apresentando na forma de leitura, uma devolutiva referente aos quatro encontros anteriores, onde resgato algumas situações:

"Tudo começou com um convite para participar de um grupo. Um grupo para coleta de dados da minha tese. Um grupo sobre qualidade de vida do aluno de enfermagem.

O convite foi aberto para os alunos das três séries $\left(2^{a}, 3^{a} \mathrm{e}\right.$ $4^{a}$ ), vários alunos mostraram-se interessados e dos doze inscritos, onze participaram. 
Vocês aceitaram o desafio, mostraram coragem para refletir, sentir e falar.

Mostraram disponibilidade para estar presentes em todos os encontros, às $6^{\text {a }}$ feiras, das 15:30 às 17:00 horas. Apesar das demais tarefas e compromissos que envolvem a vida acadêmica e pessoal.

Fred, Gisele, Paola, Mel, Rosa, Henrique, Lua, Flor, Sol, Ana e Brenda, juntos iniciaram o processo de reflexão.

Inicialmente, no primeiro encontro, a partir do tema disparador " Qual o significado de qualidade de vida?"

Rosa comenta da falta de "jogo de cintura" do professor em lidar com situações em campo de estágio, como a falta de material, com o paciente, e enfatiza : "Não vai ter quem dê apoio".

Ana revela seu sentimento de irritação ao ver que seus registros ninguém lê.

Brenda desabafa a forma com que são referidos no estágio: “... só pode ser estudante mesmo".

Henrique fala de como isso traz uma frustração danada.

A Flor conta uma situação em que uma enfermeira em depressão não teve o apoio das colegas enfermeiras, denotando falta de companheirismo. 
A Instituição...

A Mel fala dos seus sentimentos de medo e de sentir-se um nada em relação à postura da enfermeira.

Brenda, Henrique falam da postura de superioridade dos residentes em relação aos alunos de enfermagem.

Lembram também por outro lado que existe gente legal.

O grupo segue a reflexão buscando compreender esta diferença.

Sol lembra que antes o curso era integral. "...era muito bom. Tinha aquele horário de estudo... era todo mundo junto".

A falta de estrutura da Faculdade, de atividades de integração, a diferença econômica, a falta de união na enfermagem, são apontados pelo grupo como fatores que interferem na não valorização da enfermagem.

Conseguem perceber também a fragilidade dos alunos e residentes de medicina.

Os espaços conquistados pela medicina no Campus, como a quadra, a piscina não são coletivos à enfermagem. A queixa de que eles conquistaram o espaço, mas, que a Instituição também contribuiu. 
A enfermagem parece, que tem que estudar, aprender e trabalhar, sem ter o direito de lazer.

A queixa se revela ainda no desejo simbólico do mergulho da piscina, entrar em um espaço que é negado.

O aluno fala do seu medo, do seu pavor, a sua necessidade de mostrar que mudou.

A família é lembrada como colo que acolhe, ouve e abraça.

O choro silencioso e solitário do aluno.

Sobre o segundo encontro, onde falamos sobre situações promotoras de qualidade de vida, o grupo concorda como espaço de reflexão e de crescimento as disciplinas de antropologia, psiquiatria.

É lembrada a situação de acolhimento da professora de psicologia.

Ser aluno da PUC é visto como algo diferencial das demais Universidades.

E o Centro Acadêmico é lembrado como um espaço que precisa ser reformulado.

Rosa diz "Os alunos querem muitos cursos, palestras, muitas coisas querem só absorver. Queixa da não participação dos colegas em festas. 
Henrique: "Acho que festa não é o forte da enfermagem".

Depois foi retomado o convite do $1^{\circ}$ Encontro para mergulharem na piscina na busca de algo importante durante a sua formação.

Paola fala que por causa da intervenção da professora de administração passou a se empenhar e gostar mais do curso.

Ana conta sobre sua conquista em relação à transferência de escola e o quanto isto a fez gostar mais da PUC e sentir-se filha da PUC.

Rosa também declara o seu amor pela PUC.

Sol relata o caminho que percorreu para chegar na enfermagem.

Situações como conclusão da bolsa de pesquisa, monitoria, participação no Nefroriso, foram lembradas como situações potencializadoras da qualidade de vida.

Fred diz que ainda está no fundo da piscina, que talvez só depois que sair da faculdade poderá emergir. Compartilha com o grupo as barreiras que teve que enfrentar para chegar até aqui. Da sua vontade de querer, da sua perseverança e garra para chegar aqui.

Gisele diz que tem se valorizado mais, sente-se melhor.

Mel está no processo. 
A maioria dos alunos achou fácil fazer o mergulho.

O mergulho trouxe sentimentos de satisfação, orgulho, conquista, confiança, segurança e insegurança.

Compartilham também o sentimento de solidão, quando lembro que mergulhar é um ato solitário.

Ana fala do acolhimento de pessoas muito boas aqui em Sorocaba, quando se sente sozinha.

Fred vê que estar sozinho possibilita a refletir sobre si, a fazer o mergulho em si

No terceiro encontro, o grupo continua no seu processo, agora, refletindo sobre situações não potencializadoras de QV.

Utilizando-se do recurso da dramatização, os alunos de ambos os grupos trazem à tona o papel do professor, aquele que não acolhe, que ignora os sentimentos do aluno e a postura do enfermeiro de campo.

No pensar do grupo, ambas as situações retratam o não exemplo. A dicotomia da teoria e da prática e a falta de postura do professor.

O vivenciar de quem fez a cena: para Paola foi difícil e para o Henrique não, pois conta que viveu esta situação onde foi protagonista, cutucando o professor. 
O vivenciar no olhar de quem assistiu: Flor diz que o professor é o grande promotor de qualidade de vida.

Henrique diz que acha que tem mudado, mas, que certos professores não estão acostumados com alunos críticos.

Mel diz que se identifica com a situação.

Mais ninguém fala.

Ana diz que viveu de fato a cena e desabafa o seu sentimento de impotência diante da situação e do não acolhimento de ambas, professora e enfermeira.

Gisele fala que a enfermeira falou que ; "A gente só atrapalha, só que a gente faz tudo lá!"

Ana diz o quanto se sente inútil nessas horas.

O grupo retoma o movimento para falar sobre seus sentimentos em relação à abordagem do professor.

"O professor trata mal; ...parece que se sente uma pessoa superior, ...do professor só vai vir coisa ruim, ...o professor expõe a gente na sala de aula,...ele ridiculariza, ...ele ri."

Outras situações como o não reconhecimento e preconceito da profissão são apontados como não promotoras de QV. 
Quando chamados para falar dos sentimentos em relação às situações discutidas:

Lua revela : mágoa e impotência e ao mesmo tempo garra.

Flor: mãos atadas e muita insegurança.

Paola: raiva e arrependimento.

Sol: Tristeza e raiva

Gisele: Muita raiva

Brenda: Incompreensão, insegurança e chateada.

Mel: Insegurança e incapacidade.

Henrique: Desvalorização e tristeza.

Ana: Tristeza, impotência e inutilidade.

No quarto encontro, solicito para falarem de uma situação potencializadora.

Uma situação que consideraram que marcaram um gol.

A princípio, parece difícil para o grupo falar.

Sol fala que foi o seu projeto de iniciação científica

Lua considera que seu gol foi entrar na faculdade. 
Flor: quando a família reconhece o aprendizado e que quando aplicado dá certo.

Rosa: Dificuldade de apresentar trabalho, que foi superada... sentiu-se feliz e percebeu que consegue.

Paola: não desistiu

Fred: crescimento do lado humano.

Ana: monitoria da parasitologia.

Brenda: Adquiriu conhecimento e pode estar ajudando seus familiares...

Gisele: "... acho que amadureci bastante....eu achava que não levava jeito... eu me apego muito aos pacientes.... coisa que antes eu era distante deles."

Sol: acrescenta dizendo da sua experiência de dois anos no Ambulatório.

Depois disto vocês foram convidados a ouvir a música:

Tente outra vez (Raul Seixas/ Paulo Coelho/ Marcelo Motta).

A música foi tomando o ambiente. Envolvidos pela letra e melodia, o silêncio de cada um desvelou o sentimento que emergia dentro de si. 
Emoção, sorrisos, lágrimas, paz, harmonia, pudemos

observar.

A música acaba, é hora de falar sobre o que a música tinha a ver com cada um.

Paola imediatamente responde; "Tem tudo a ver. Eu não tentei uma vez eu tentei duas... eu acho que tentei bastante, mas era o que eu queria".

Rosa: "...a gente só vai ser vitorioso se a gente tentar."

Mel: “...ser perseverante.”

Flor: emocionada diz: "Essa música é linda."

Flor: "A vida inteira a gente vai ter questões pela frente."

Gisele: "Não é porque surge um obstáculo que a gente vai desistir."

Lua : "Tem que trabalhar muito a paciência."

Sol: "O que mais me chamou a atenção foi a fé em Deus, é importante a religião, você tem que acreditar em algo."

Após esta reflexão, o grupo foi convidado para expressar como pode ser construída a qualidade de vida durante a formação.

Faço agora alguns comentários sobre a apresentação de cada sub-grupo: 
Sub-grupo 1: Gisele, Sol, Fred e Brenda

Vocês apresentaram basicamente atitudes que dependem de vocês e de outros. Trazem contribuições de forma subjetiva que podem ser concretizadas e então pergunto: de que forma? De quem depende isto?

Sub-grupo 2: Paola, Lua e Rosa

Seguem o estilo do outro grupo também. Parecem apontar para as ferramentas e não para o como fazer.

Sub-grupo 3: Mel, Henrique, Ana e Flor

Enfatizam a união. Também ficam na subjetividade.

Convido a vocês a retomarem esta reflexão.

Pensar mais de forma objetiva, durante o acontecer desses encontros resgatar os significados e as situações promotoras e não promotoras de QV.

Vamos ver que no primeiro encontro descobrimos a falta de acolhimento do aluno por parte do professor, da Instituição, do campo de estágio. Constatamos a queixa de um desacolhimento.

No segundo encontro, a proposta do desafio do mergulho. Este encontro foi pautado pela reflexão de situações que favoreceram a qualidade de vida. $O$ mergulho da piscina possibilitou $o$ resgate de potencialidades de cada um. 
No terceiro encontro, percebo que o grupo avançou na reflexão e no sentir, mas ainda não percebeu estratégias de enfrentamento. Parecem estar descolados de si e centrados no outro. A música também me disse, pois as frases começam sempre com o verbo na terceira pessoa do imperativo (Veja, Tenha, Tente, Beba, Queira, Vai) que para tentar outra vez é preciso viver o nosso papel de protagonista e não de meros expectadores da vida.

O grupo apresenta também uma capacidade de constituir vínculos bons, e com isso, podem desenvolver um espaço solidário. Pensar em propostas de mudanças locais e estratégias de enfrentamento.

Quero também dizer ao grupo que soube acolher a mim e a observadora, o quanto corajosos foram em estar aqui e falar de si mesmos; o quanto puderam fazer deste processo um crescimento do grupo.

Empresto agora a fala de uma outra pessoa, não integrante do grupo, que apresento a vocês:

"Mais do que o gesto, interessa como ele foi recebido. Mais do que a palavra, nos influenciamos como ela foi ouvida. Mais do que o fato, vale onde, como e quando ele nos tocou."

(Lya, Luft, Senhora de preciosa poesia)

Em seguida, passo a palavra para aquela que nos ouviu no seu silêncio. A observadora. 
A observadora passa então a fazer uma síntese dos quatro encontros, que descrevo a seguir em forma de depoimento:

“...é uma proposta bastante arrojada, eu acho no contexto de uma área como esta, na área da saúde, é diferente e bastante desafiadora, quando a gente é convidado a falar, tendo a presença de uma professora que foi de muitos, se não foi de todos, acredito que será em algum momento".

“...foram quatro encontros bastante intensos, então, as pessoas não são todas da mesma classe, então eu acho que existiu, não sei se vocês já se conheciam antes daqui da faculdade. Não sei como era isso, mas, uma relação em profundidade entre todos não existia ainda. Então, o que acabou acontecendo, apesar do dia, do horário, como a Raquel também apontou, vocês estavam bastante presentes de corpo e alma."

“...pude observar e ficou muito clara a coragem que o grupo demonstrou durante todo o tempo, a coragem em ousar em aceitar uma proposta diferente da do cotidiano de trabalho de formação de vocês e a coragem de terem permanecido e terem exposto não só o que pensavam, que é muito fácil, mas o que vocês sentiam, o que é muito mais difícil." "...vocês fizeram todos os encontros com muita participatividade, o que muito me surpreendeu."

“...outra coisa é a figura do observador, que é algo muito estranho no grupo. Ele é um estranho, porque realmente ele é desconhecido, é uma figura que está lá anotando tudo o que eu falo, não diz uma palavra e nem olha para mim, então, gera muito desconforto, e eu acho que vocês conseguiram trabalhar muito bem com isso, de uma maneira muito tranqüila, o que não é tão comum assim. Eu me senti bastante acolhida neste grupo, sem dúvida nenhuma. Eu não conhecia as pessoas e acho que 
acolhimento é também uma palavra que define muito o processo que vocês fizeram aqui dentro."

"...ao mesmo tempo que vocês tiveram a coragem de se expor e também explorar as questões que vocês estavam trazendo, porque este lugar não era um lugar só de depositação, isso também eu achei bastante interessante no grupo. Não era um lugar de queixas, de poliqueixas, poderia ter virado, e não, mas, era um lugar de discussão, de reflexão. As questões foram trazidas mas foram elaboradas, muitas das questões que vocês trouxeram foram trabalhadas por vocês e não de uma maneira queixosa de lamento, de catalogação do que não estava legal."

“... grupo trouxe um olhar de uma relação que já está posta para vocês, da importância de poder olhar o lado pessoal quando se pensa em qualidade de vida no trabalho e neste lado pessoal, vocês trazem a família, crença, relacionamento, cuidar da própria saúde, enfim, isso é uma coisa que a gente também observa."

“...uma questão que eu acho que atingiu os encontros e aí a gente pode conversar sobre isso, mas, o grupo manifesta uma necessidade de escuta e de reflexão, acho que vocês apontam isso no 2 ou no 3 encontro, que a PUC, que a instituição mobiliza bastante o aluno, chacoalha, mas, se alguém não tem essa prática, a instituição vem e chacoalha essa pessoa. Para mim vocês já estão fazendo na Universidade, me parece que há uma necessidade de acolhimento e troca, ao mesmo tempo a gente fala de pares de contradição, que são idéias contraditórias e que acabam surgindo, que se articulam e complementam-se, apesar de serem contraditórias. Então, ao mesmo tempo em que isto aparece, acontece uma acolhida muito grande do grupo, quando manifestam-se os sentimentos, situações diferentes, paralelamente a isto; contraditoriamente vocês trazem muito forte em vários encontros, o quanto a Enfermagem não tem essa união da classe, isto é contraditório, é real, não é só do professor de 
enfermagem, mas, de acordo com o que vocês trouxeram fica bastante claro que isto acontece, porém, que é outrossim, um espaço onde vocês fizeram o acolhimento um dos outros e conseguiram em muitos momentos manifestar o desejo de fazer a diferença e acho que se vocês não encontram isso nos diferentes espaços da Universidade, acabaram fazendo isso aqui de uma maneira bastante notória." “...vocês não reproduzem aqui a competitividade que vocês falaram que existe na classe ( em campo, com os colegas)."

Concluídas as devolutivas, solicito que todos fechem os olhos e identifiquem quais os sentimentos presentes naquele momento dentro de cada um.

Os integrantes que se manifestaram: Flor : “..esperança, que a falta da união melhore,...é bom saber que tem gente querendo discutir.”

Henrique revela dois sentimentos: "Dois sentimentos contraditórios, vontade de conquistar novas coisas e por outro lado, ter paciência."

Flor: " acho que vai assim até o último dia de aula, não muda muito não."

Após um momento de silêncio proponho: “... a gente vai ter um tempo agora para discutir sobre a devolutiva. $O$ que acharam, o que estão pensando sobre isso"

Imediatamente, um dos integrantes se colocou falando a respeito de suas impressões sobre a devolutiva: Lua: "O sentimento que 
mais bateu fé, acreditar que tem que ser diferente, tem que melhorar, tem que pensar..."

Rosa completa: “... as coisas que a gente falou, não fugiram da realidade, mas não imaginava que dava para enxergar tanta coisa no que a gente falou..." e ao ser perguntado, sobre os sentimentos suscitados respondeu: “... não sei como explicar. Foi legal.”

\section{Mais um momento de silêncio e então retomo uma} solicitação do encontro anterior: “... na semana passada dei uma tarefa de casa para vocês. Lembram-se? Como é que era a qualidade de vida de vocês. E então, pensaram ?"

O grupo falou da fase de transição que alguns dos integrantes estão vivendo, seja porque se percebem em um momento de auto-conhecimento e descobertas sobre si, seja porque estão prestes a concluir o curso e se tornar profissionais tendo que fazer escolhas com relação ao direcionamento da carreira, ou ainda porque se encontram em meio a situações de mudança: Ana fala: "A minha (qualidade de vida) ... não está do jeito que eu queria ...estou passando por momentos de me conhecer e aprender a gostar de mim ...”; Rosa declara: “... a minha está péssima, mas eu estou em mudança de rotina ... mas isso é uma questão de tempo ...”; Flor comenta: “... a gente está numa fase muito boa, formatura ... dúvidas, o que eu faço da minha vida agora ... Fica com vários caminhos ... e tem que escolher um ..." 


\section{Relembrando a fala de um dos integrantes sobre o} quanto a devolutiva possibilitou "ver muito mais coisas que não tinha visto ..." peço que o grupo reflita sobre a construção da qualidade de vida.

Então a participação de cada um é reconhecida como aspecto importante nessa construção, ora como parte de um conjunto, ora individualmente: “... são coisas que em parte dependem dos alunos ... se todos estiverem interessados fica mais fácil ..."; "Por ser uma coisa muito pessoal, se todo mundo tiver se empenhado ...cada um vai buscar a sua." ( Lua)

É referido também o papel do conflito como mobilizador da pessoa para a mudança: Henrique: “... acho que as coisas só mudam quando gera conflito, quando incomoda ..." então após mais um momento de silêncio pergunto: "O Henrique falou que as coisas só mudam quando acontece o conflito ... Quando o conflito acontece qual é a minha atitude?"

O grupo aponta diversas maneiras de reagir a um conflito, explorando inicialmente o par de contradição enfrentar "versus" paralisar e em seguida, passando a problematizar os significados da não reação que pode se traduzir em cautela diante da situação ou em um momento para refletir sobre o que está havendo: Mel: "Ou a pessoa fica parada ou evolui"; Rosa: “... tem as que só vão reclamar ... e as que vão se envolver”; "... tempo para refletir”; Lua: “... não pode ser imediatista ...” 
Pergunto: “... é escolha nossa estarmos do jeito que estamos ?" e relembra o fato de não poderem freqüentar a piscina da Medicina. Seguem-se comentários rápidos e a coordenadora esclarece: “... como é que vocês resgatam o conflito de não poder entrar na piscina ...?”

O grupo menciona o respeito às regras sociais como limite à liberdade e também a falta de um interesse maior por parte dos alunos em freqüentar a piscina: Henrique aponta: “...regras sociais... independente da gente ... o homem acha que é livre mas nunca será livre ...”;Flor pensativa diz: “... não sei se há um interesse ...”. Então a relembro alguns aspectos apontados pelo grupo a fim de enriquecer a discussão: “... falta de união (entre os alunos da enfermagem) e espaço de lazer, ... uma fala diz que a instituição ajudou-os (alunos da Medicina) ... mas que eles são unidos ...”

Falam a respeito da real vontade/necessidade de ter acesso à piscina: Lua refere: “... se realmente o pessoal falar que quer ... é porque não há vontade ..."

Novamente faço uma outra intervenção: "O que o grupo acha do que a Lua comentou em relação a não ter a necessidade ... E quem é que vai sinalizar essa necessidade ?’

Várias falas trazem de novo a postura dos professores e também da instituição de não apoiarem as iniciativas dos alunos: Henrique desabafa:“... por outro lado não tem muito estímulo não ... poucos 
professores apoiavam (refere-se aqui ao grupo de teatro da enfermagem) ..."; "A PUC tem um caráter resistente ao que é diferente"; "Tradicionalista."

Em seguida, peço que avaliem o espaço proposto: “... vou pedir para vocês falarem como vocês se sentiram nesse espaço."

Alguns classificaram como terapêutico, comparando a iniciativa a uma terapia de grupo; outros ressaltaram o caráter de espaço de troca de experiências e de acolhida: Brenda:“... é uma terapia em grupo e é muito bom ..."; Lua: "foi muito terapêutico para todo mundo ..."; Rosa: "O que foi muito positivo é ser cada um de um ano ..."; "cada turma carrega uma história, uma vivência e é legal poder trocar essas idéias ...”; Henrique: “... a gente não teve aquela pressão ... a gente ficou bem à vontade ...”; Lua "a gente tem muito medo de ser julgado, avaliado ... Aqui não, foi gostoso..."

O desejo de que propostas semelhantes fossem mais freqüentes foi também apontado, bem como, alguns lamentos pelo término dos encontros: Brenda:“... foi muito bom. Sempre deveria ter ...” Rosa lamenta: “... a gente devia ter um espaço mais assim. Estou muito triste porque não vai mais ter."

Ao final, propus uma dinâmica, em que cada um representaria através de desenho ou escrita, um presente que gostaria de dar à alguém do grupo; porém, sem que devessem se identificar ou identificar o colega que seria presenteado. As folhas, depois de prontas, seriam colocadas em uma caixa de presentes de onde seriam retiradas por cada integrante, aleatoriamente. 
Em meio a brincadeiras realizaram a dinâmica e compartilharam os presentes que estavam nas folhas de papel retiradas por cada um, da caixa.

\section{Minhas Impressões}

Em relação à comunicação, percebe-se a predominância de alguns integrantes em relação à participação verbal e presença de muitos momentos de silêncio ao longo do encontro.

Refletiram um pouco sobre como se encontram com relação à própria qualidade de vida e compartilharam suas opiniões e alguns sentimentos sobre a importância de propostas como essa, em que há o intercâmbio de vivências para o desenvolvimento pessoal.

Inicialmente, o grupo demonstrou-se um pouco tenso, em função da devolutiva que, aliás, pareceu ter sido bastante impactante para o grupo, visto que houve muitos momentos de silêncio e o grupo como um todo não conseguiu explorar, com alguma profundidade, os sentimentos e impressões a respeito da devolutiva.

Ao final marcada pela emotividade e momentos de descontração.

Demonstraram mais uma vez haverem valorizado a possibilidade de estar em grupo, a troca de experiências e a oportunidade de um aprendizado individual, a partir do que foi trazido pelo outro: “... aprendi um pouco com cada um ... palavras que foram ditas, experiências ...”; “... 
deu para se emocionar ... eu me emocionei muito com a história da Ana ..."; “... para mim foi bom pegar um pouco de cada um ...”

De um modo geral demonstraram boa qualidade de relacionamento, tendo em vista o tempo proposto (cinco encontros).

Algumas idéias (pares de contradição) puderam ser identificados: "ficar parado" e "evoluir"; ação que desempenho e ação que espero; o que depende de mim e o que não depende de mim. 


\section{DISCUTINDO OS ENCONTROS}

Para discussão dos encontros, revisitamos exaustivamente a literatura que compõe o referencial teórico no Capítulo. 3 e nela encontramos reiterado o consenso de que, o conceito de QV, apesar de amplamente utilizado nos últimos anos e ainda hoje, inexiste uma definição que seja aceita universalmente. É possível afirmar que o conceito de QV, vem sofrendo modificações que acompanham a dinâmica dos diferentes contextos sociais com suas diferenças culturais, suas prioridades e crenças.

Retomando um definição que abarcasse maior amplitude, a OMS, declara QV como: "a percepção do indivíduo de sua posição na vida no contexto da cultura e sistemas de valores nos quais ele vive e em relação aos seus objetivos, expectativas, padrões e preocupações” (Fleck, 1998). Essa definição tem sido uma referência importante, na maioria dos estudos sobre a temática.

Ao tratarmos especificamente de QVT, os estudos de Wanton, "apud" Haddad, enfatizam que QVT visa a proteção do empregado e a propiciar-lhe melhores condições de vida dentro e fora da organização. Segundo esse autor, para que a QVT seja alcançada, é necessário que o trabalhador tenha: remuneração adequada e justa; condições de segurança e saúde no trabalho; oportunidade imediata para utilização e desenvolvimento da sua capacidade humana; oportunidade para 
crescimento contínuo e segurança; integração social na organização, participação na organização do trabalho; condições favoráveis entre trabalho e espaço total da vida e a relevância social da vida no trabalho. Esse referencial tem sido, também, amplamente citado e utilizado, em grande parte dos estudos sobre QVT.

A respeito de indicadores específicos de QVTEnf.; retomamos os identificados por Carandina (2003), em seu estudo com enfermeiras trabalhadoras em Instituições hospitalares, onde são definidos como indicadores de QVT de Enfermagem: aspectos que envolvem o relacionamento inter-pessoal vertical e horizontal; o reconhecimento profissional; a preocupação com a qualidade do trabalho desenvolvido; a autonomia e estabilidade no emprego; a operacionalização do trabalho diário; as condições ergonômicas; a remuneração e recompensas; o tempo destinado ao trabalho e as oportunidades de crescimento profissional; a profissão e aspectos relacionados com o pessoal e material disponível para trabalhar.

Embora não tenhamos encontrado na literatura um grande número de trabalhos que tem como objeto específico de estudo a QVTEnf. como o realizado por Carandina (2003), evidenciamos que o tema perpassa diferentes estudos que tratam de outras temáticas. Esses estudos que direcionam-se para a relação saúde- trabalho na enfermagem em suas diferentes vertentes (ergonomia, stress e coping, abordagem psico-dinâmica do trabalho onde busca-se a relação sofrimento - prazer; os estudos que 
versam sobre fatores geradores de acidentes de trabalho ou os determinantes de cargas e riscos ocupacionais, onde se recupera os nexos biopsíquicos que incidem sobre os trabalhadores em diferentes postos de trabalhos na Enfermagem); indiretamente, abordam questões pertinentes à qualidade de vida no trabalho. Contudo o descritor não aparece relacionado ao tema.

No que se refere à qualidade de vida de estudantes universitários, QVE, na pesquisa de Benjamin (1994) este define-a como "a percepção de satisfação e felicidade, por parte do estudante em relação a múltiplos domínios de vida à luz de fatores psicossociais e contextuais relevantes e estruturas de significados pessoais". Nesse estudo o autor pesquisa a QVEst. Universitários, por meio de uma ampla revisão bibliográfica de artigos publicados no contexto Norte - Americano.

Nesse trabalho de revisão da literatura, os domínios de vida reconhecidos, segundo Benjamin (1994), são: social; individual; acadêmico; gênero; finanças; moradia; serviços da universidade; administração universitária e outros (entre estes, saúde).

Quanto aos estudos específicos sobre qualidade de ida de estudantes de enfermagem, QVEst. de Enf., encontramos na revisão da literatura nacional 03 estudos desenvolvidos por Kawakame e Miyadahira (2005), Saupe (2001) e Iglesias e Kimura (2000). Nestes estudos, as autoras se utilizaram de escalas que e quantitativa desses índices. 
Deste modo, optamos por desenvolver um modelo próprio, que fosse capaz de apreender a qualidade de vida do estudante de enfermagem, privilegiando os aspectos qualitativos, da percepção dos mesmos, segundo suas experiências. Para tanto, partimos do modelo proposto por Benjamin (1994), por ele denominado de Modelo Ecológico.

A proposta do Modelo de Benjamin, vai ao encontro com os pressupostos da pesquisa qualitativa, a medida que reconhece a QVE como sendo de caráter multidimensional e, como consequência da interação dinâmica do tipo do estudante, dos eventos situacionais, dos estágios de transição por ele vividos e do ajuste pessoa-ambiente através dos domínios de vida relacionados às experiências nos diferentes contextos.

A análise dos encontros grupais, indicam claramente que os colaboradores, ao pensarem no significado de QV, relacionam-a com os diferentes conceitos estabelecidos pelos autores pesquisados na literatura. Esses conceitos, ora apontam para uma interface entre a qualidade de vida no trabalho, ora para a qualidade de vida enquanto estudante. Na discussão dos conceitos, os sujeitos participantes destacaram que o tema está intimamente ligado não somente à vida profissional, como também, à vida pessoal, e que o mesmo faz parte do cotidiano de cada um.

Tendo em vista que o cenário do estudo compreende o universo de formação do enfermeiro, surgiram aspectos específicos que envolvem o aluno em suas inter-relações com outros alunos, professores, 
profissionais, familiares, e que por conseguinte, refletem na sua qualidade de vida.

Consideramos que a estrutura de significados atribuídos à qualidade de vida pelo estudante de enfermagem sofre a influência de múltiplas domínios do vivido, que devem ser interpretados de forma dinâmica e multidimensional.

No intuito de apresentar essas representações dos múltiplos domínios da qualidade de vida do estudante de enfermagem, optamos por construir um esquema, que embora incompleto pelo fato de restringir-se a um único plano gráfico do papel, pode ser tomado como referência para entendimento da complexidade, dinamicidade e multidimensionalidade das dimensões embutidas nesse estudo. 


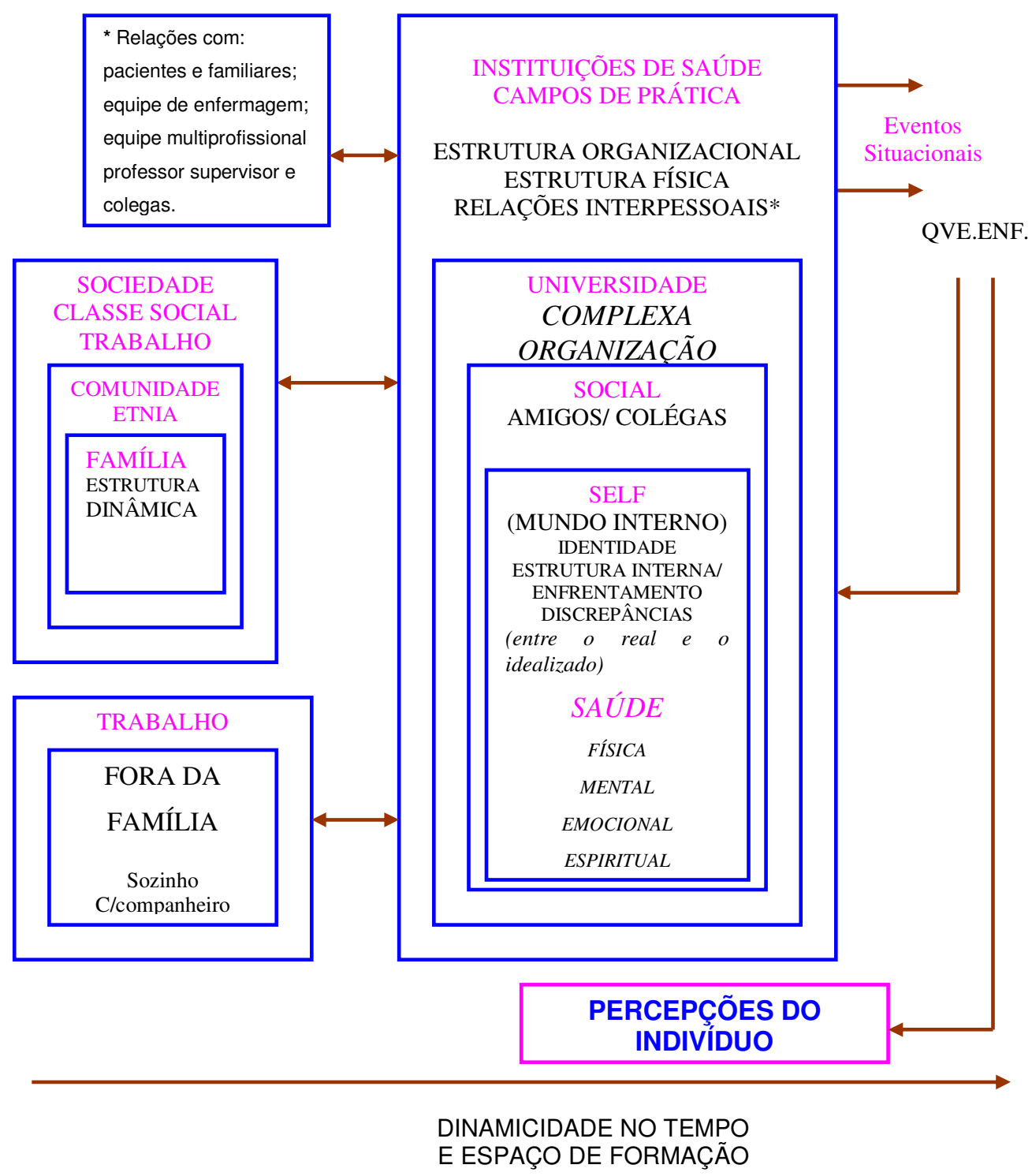

Figura 2: $\quad$ Modelo Ecológico de QVEEnf. adaptado do proposto por Benjamin (1994).

Como descreve o modelo apresentado na Figura 3, observamos uma série de contextos que envolvem a experiência de formação dos alunos de enfermagem. Segundo o esquema, o sujeito/aluno 
sempre está inserido em um determinado contexto social, representado pelas dimensões estrutural, particular e singular. Na dimensão singular, insere-se na família com sua organização e dinâmica peculiar. Na dimensão particular, as instituições às quais o sujeito pertence são influenciadas pela estrutura que determina nestas as formas de interação, e as relações de poder e subordinação. Finalmente, na dimensão estrutural, a sociedade à qual pertence com sua forma de produção e reprodução social, define e condiciona o pertencimento do sujeito a uma dada classe social que, em última instância, define as condições de vida, de acesso a bens e consumo, bem como as condições de trabalho.

Na família, fonte primária de socialização do sujeito, são fundados seus valores, tendo como referência as vivências e a dinâmica própria da família com seus integrantes, no contexto das etnias e culturas específicas dos grupos homogêneos. Isso determina um outro "status" social e de acesso a bens e serviços, bem como, oportunidades de ingresso em carreiras e no mercado de trabalho.

Desse ambiente familiar provêm as primeiras valorações positivas ou não, em relação à escolha da carreira que o sujeito irá cursar.

Em seguida, já no contexto de formação do aluno de enfermagem é possível apreender o domínio do "self" individual, da identidade, (acadêmica, social, pessoal, seu estado afetivo), as expectativas, os valores e discrepâncias entre as aspirações do estudante e a sua realidade. Em um outro âmbito, temos a perspectiva de valoração da saúde 
física e mental; da vida no contexto social da universidade, incluindo as relações com amigos e professores, funcionários, a vida no campus, as relações com outros cursos, espaços de lazer, a vivência no próprio curso (currículo, disciplinas, estágios), e com as organizações com as quais tem contato, (Universidades e Serviços de Saúde), com suas estruturas próprias que determinam a organização das atividades curriculares e extracurriculares, avaliações, horários. Nessas organizações, no contexto de aprendizagem em instituições de saúde são consideradas as especificidades da relação com a estrutura organizacional e com a estrutura física (espaço físico, recursos materiais e humanos). Nas relações interpessoais destacamse, de modo significativo, as relações com o paciente/cliente e seus familiares, com a equipe de enfermagem, com a equipe multidisciplinar, com os professores, supervisores e colegas. Estudos evidenciam que tendo em vista as especificidades do próprio objeto de trabalho no processo de trabalho assistir/cuidar, (o doente em situações de sofrimento) este contato gera cargas que são específicas ao trabalhador de enfermagem, que influenciam a qualidade de vida tanto do estudante, quanto do trabalhador. Felli (2002)

Mantivemos os contexto fora do ambiente familiar, indicados por Benjamin, para expressar a situação do aluno que mora com o conjugue, namorado(a), colegas ou sozinhos. Neste contexto, incluímos o trabalho do aluno, pois, no curso de enfermagem, cenário do estudo, temos situação de alunos trabalhadores, que dependem do próprio trabalho para seu sustento e manutenção do próprio curso. 
Esse modelo foi utilizado por nós utilizado como referência principal para a análise do material produzido nos encontros grupais, por considerarmos que devido à sua amplitude, demonstra potencialidade para captar a realidade de modo a não perder a totalidade e dinamicidade da mesma em relação à práxis.

Desse modo, nos depoimentos dos colaboradores no primeiro encontro, identificamos alguns domínios citados pelos autores que tratam de QVT. É possível identificar que os participantes fazem identificações projetivas quanto ao futuro profissional, considerando a questão da carga horária excessiva de trabalho; a baixa remuneração e o mercado de trabalho que exige produtividade. Outro ponto ressaltado é a insegurança gerada pela não reconhecimento e valorização das atividades executadas pelos alunos durante a formação. Isso é por eles percebido, tanto por parte do docente, dos enfermeiros de campo, como outros profissionais. A falta de acolhimento dos enfermeiros em relação às dificuldades vividas no início da profissão; os conflitos gerados a partir do enfrentamento de situações profissionais em diferentes contextos vividos na formação, a preocupação em dar continuidade a uma assistência de qualidade para os clientes e o desejo de serem profissionais diferentes dos modelos que encontram no campo prático, constituem-se em dilemas para o aluno de enfermagem, que interferem desfavoravelmente em sua qualidade de vida. 
Domingues (2005), ao estudar a indisciplina dos alunos do curso de administração e a sua relação com a sua qualidade de vida desses estudante, apreende que estes ao considerarem que o mundo do trabalho se apresenta como "mercado competitivo e traiçoeiro", tem as ansiedades mobilizadas por este contato e não encontram um espaço onde essas possam ser reconhecidas no grupo. A pesquisa mostra que as ansiedades permanecem no nível individual e as estratégias defensivas são direcionadas mais ao auto-controle e menos à criatividade. Nesse contexto, o alto nível de ansiedade dos alunos dificultam o aprofundamento dos vínculos. Como resultado desse processo, os alunos idealizam o grupo de pares e assim, negam que possam se assemelhar ao modelo de profissional que encontram no mercado de trabalho que irão enfrentar; e ainda, temem toda e qualquer divergência que possa ameaçá-los, resultando em comportamentos de indisciplina.

Do ponto de vista ainda da autora, os alunos por não terem um momento de elaboração dessas ansiedades não se preparam para enfrentar o mercado de trabalho que é por eles temido. Não exercitam suas potencialidades e ousadias na busca de soluções.

Neste aspecto, percebo que os alunos de enfermagem vivem grande parte da sua formação em campo prático, onde se espera que estes "dêem conta" das atividades da assistência e que realizem todos os procedimentos de forma adequada e em tempo hábil. Considerando-se, ainda, as condições da instituição e a deficiente relações interpessoais que 
os alunos estabelecem no cotidiano e que, ainda, estes estão em um espaço transitório (as instituições de saúde), onde nem ele nem o professor tem poder decisório, que é do profissional, seria fundamental que houvessem momentos de elaboração dos sentimentos oriundos dessas experiências vividas, ainda no processo de formação.

Ao contrário do que acontece com os estudantes de Administração, que participaram do estudo de Domingues (2005), que demonstram comportamentos de indisciplina, são notórias, nos depoimentos dos alunos participantes dos grupos, no presente estudo, as questões que denotam a vivência de práticas que pouco privilegiam ações direcionadas ao desenvolvimento da elaboração, da autonomia e criatividade. Apreende-se que ocorre uma adaptação passiva dos mesmos à realidade, expressa por uma disciplinarização no decorrer do curso.

Nessa mesma direção, Oliveira et al (2000) discute que há muitas situações que favorecem a disciplinarização das futuras enfermeiras, estimulando a negação de si como ser humano, fazendo que estas tornemse, por vezes, um mero objeto, pois não são valorizadas as suas histórias, o seu saber prévio, assim como seus sentimentos, idéias, anseios e necessidades.

A partir do segundo encontro, a narrativa dos colaboradores mostra quais são as situações promotoras de qualidade de vida. Apontam que o contexto da vida acadêmica propicia mudanças, conquista da sua identidade e certa liberdade, em relação à vida pessoal, quando vivem as 
experiências inerentes ao morar fora de casa, quando são provenientes de outras cidades.

Assinalam que as disciplinas de Ética, Psiquiatria e Antropologia, possibilitam a reflexão e a crítica e a pensarem na sua qualidade de vida. Por serem estas disciplinas da área de Ciências Humanas, estas foram lembradas como espaços importantes para suporte dos aspectos relacionais, percebidos como promotores de QV.

O atendimento oferecido pelos funcionários da escola: da secretaria, da biblioteca e de outros setores, é citado pelos colaboradores, como sendo de muita importância, no sentido de acolhimento e de poderem contar com um "ombro amigo".

O cuidado prestado aos clientes, quando contribui para a sua melhora de condições de saúde, é referido como fonte de satisfação e bem estar para o aluno. Presencio na prática docente que acompanha os alunos nas atividades práticas, situações em que os mesmos demostram alegria e satisfação quando podem perceber resultados imediatos de melhora do cliente, a partir da sua assistência.

Neste sentido, Gutierrez (2003), estudando o cotidiano da equipe de enfermagem em UTIs ao indagar-se: "onde os profissionais de enfermagem encontram forças para conseguir superar diariamente 0 trabalho penoso?", encontra como resposta que essa força advém da gratidão expressa pelo cuidar do outro como a essência da profissão." 
Oliveira et al (2000) observa, ainda, que este servir implica uma negação e esquecimento de si, dos seus desejos, vontades e aspirações que parecem não se concretizar senão na realização e na satisfação do outro.

O processo grupal mostrou que é preciso possibilitar ao aluno expandir esta satisfação de cuidar do outro para o cuidado de si e para o cuidado entre si, isto é, entre os colegas e professores. Para tanto, o docente que ensina, também deve estar preocupado em cuidar do aluno e do grupo em suas relações de ensino, pois o professor também é percebido como modelo para o aluno ou, um anti-modelo.

Os depoimentos no grupo enfatizam o quanto 0 relacionamento acolhedor da professora de administração facilitou o seu processo de amadurecimento.

A pesquisa de Cavalcante (2003) que estuda a humanização da assistência, enfatizando a necessidade de humanizar o ensino, descreve as estratégias facilitadoras no ambiente de aprendizagem adotadas pelo professor, segundo os colaboradores de seu estudo: atuar como mediador do conhecimento, favorecer a autonomia do aluno, estar próximo do aluno, perceber o potencial do aluno.

O depoimento do porta-voz nesse segundo encontro, em que aponta o comportamento do professor como promotor de qualidade de vida para o aluno, reitera os resultados obtidos na pesquisa de Cavalcante (2003), pois evidencia que intervenções de acolhimento por parte do docente 
propiciam que o aluno melhore a sua auto-estima e passe a protagonizar a sua história, a partir de referências positivas.

As atividades acadêmicas extra curriculares, como participação em Pesquisas de Iniciação Científica, Ligas e no Projeto Nefroriso, são apontadas em consenso, pelos alunos participantes, como espaços promotores de qualidade de vida. Os alunos encontram, nesses espaços, oportunidades para exercitarem uma aprendizagem ativa, dialogada, desenvolverem a criatividade, a capacidade de trabalhar em grupos e terem o seu trabalho reconhecido.

A organização dos alunos em relação à participação do Centro Acadêmico é percebida como tendo falta de articulação entre os mesmos, característica também evidenciada por eles na categoria dos enfermeiros. Estes são percebidos como pouco participativos de atividades e articulação política para reivindicações de melhoria para a sua categoria, como classe trabalhadora.

Esse comportamento pode ser explicado pela construção histórica da profissão que se desenvolveu em um contexto de pratica religiosa, caritativo, marcado por normas e limites rígidos, sem reconhecimento da prática como trabalho profissional, mas sim, como uma atividade que seria recompensada, em uma outra dimensão da vida pósmorte.

Isso retrata a influência das religiosas, tanto na prática, quanto no ensino de enfermagem, impregnada pela representação de 
prática cuidativa como missão e espírito de servir a um ideal e pelo servir ao outro, seja este: o doente, o médico, as chefias, os administradores das instituições. Neste sentido, os resultados dos encontros grupais apontam na mesma direção de Oliveira (1998) quando considera este servir uma negação e esquecimento de si, dos seus desejos, vontades e aspirações que parecem não se concretizar senão na realização e na satisfação do outro.

Esta representação, embora tenha perdido sua força, ainda se reflete no contexto de trabalho atual da enfermagem. Isto pode ser percebido em relação às horas de trabalho, que ultrapassam a jornada legal, ao rigor no cumprimento de disciplina, à baixa remuneração recebida, com pouco reconhecimento social pelo trabalho prestado e as condições de trabalho, muitas vezes insalubres.

Estas são evidências que mostram a importância de se ter Políticas de Recursos Humanos que adotem a preocupação com a qualidade de vida dos trabalhadores de enfermagem, identificando e intervindo sobre as situações potencializadoras de um perfil desfavorável de saúde e de vida desses profissionais.

No $3^{\circ}$ Encontro, os colaboradores comentam situações não promotoras de QV que se relacionam a domínios referentes às instituições de ensino (campus e demais locais de estágios). No que se refere ao campus, foi assinalada a falta de atividades para os alunos de enfermagem, espaços de acolhimento e de lazer, para os alunos de enfermagem. Neste 
aspecto, referem, ainda, o quanto os alunos do curso de medicina são privilegiados em relação aos de enfermagem no que se refere aos espaços de lazer que estes tem e que não são compartilhados, no campus, com os demais cursos.

Quanto aos locais de estágios, trazem as questões das relações conflituosas com as enfermeiras já formadas e com as demais categorias profissionais.

A narrativa dos alunos mostram que a dimensão das relações interpessoais no trabalho e na vida de estudante são geradoras de insatisfação, quando reconhecem as dificuldades de relacionamento entre os cursos e no próprio curso de enfermagem. Revelam questões de desunião e competitividade entre os alunos.

Quando abordam a relação professor-aluno, no processo de formação consideram que prevalecem as situações geradoras de medo, insegurança e pressão.

Neste aspecto, Cavalcante (2003) descreve como características dificultadoras da aprendizagem, segundo os colaboradores de seu estudo, também alunos de graduação em Enfermagem: a aprendizagem da teoria diferente da prática; o medo do professor; o professor que adia a resposta às perguntas; o professor que não responde às perguntas dos alunos; o professor frustrado; a não familiaridade do professor com a especialidade; a insegurança do professor quanto ao desenvolvimento do aluno e quanto ao conhecimento; o professor que não 
tem vivência com o aluno e as dificuldades dos alunos que não trabalham na área.

Esses resultados mostram consonância com os relatos dos colaboradores da presente pesquisa, que abordam a dicotomia da teoria e da prática; a falta de acolhimento por parte do professor supervisor; o professor que expõe o aluno; o professor que vai ensinar e não sabe os passos importantes e o professor que não está preparado para lidar com o aluno crítico.

As dificuldades vivenciadas pelos colaboradores, alunos do curso de graduação da PUC, são comuns, em parte, ao que Ângelo (1989), denominou em pesquisa intitulada como "Vivendo uma prova de fogo". Essa autora enfatiza que o início da aprendizagem da prática de enfermagem é correspondente a uma vivência difícil e frustrante. Assim, a relação a ser desenvolvida com o professor deveria facilitar e não dificultar a interação, o ensino, o aprender e o querer ser enfermeiro, pois, mediante a relação com o campo, com os professores e profissionais, o aluno toma a decisão de continuar ou desistir da profissão.

A convivência com os enfermeiros de campo é percebida pelos colaboradores da presente investigação, como um indicador de conviver com o não exemplo e pela falta de acolhimento. Esse foi um tema recorrente nos encontros.

Os alunos revelam que estas situações vivenciadas por eles em campo prático, geram sentimentos de impotência para si, tanto no 
sentido pessoal quanto no sentido profissional, implicando em uma baixa auto-estima, bem como, uma desvalorização da profissão.

Os alunos observam que algumas enfermeiras exercem a profissão desempenhando funções que não seriam de sua competência, deixando de realizar outras entendidas como específicas de sua atuação, o que se reflete de modo negativo na assistência prestada ao cliente.

Quando o aluno começa a pensar criticamente em relação à enfermagem percebe que algumas enfermeiras se posicionam e agem de forma divergente do que aprenderam na graduação e, com isso, começam a refletir sobre sua própria forma de agir enquanto aluno mas, também, como futuro profissional.

O período de formação constitui-se um tempo, onde os alunos vivem a experiência de se conhecer como parte do ir se preparando para ser profissional. Muitas vezes, a sensibilidade estando excluída das relações interpessoais, acarreta perda de um canal importante para acessar a leitura da realidade, para a compreensão empática do outro.

No quarto encontro, os colaboradores identificam experiências acadêmicas que foram promotoras de qualidade de vida, como: participação em atividades extra curriculares em ambulatórios e estágios, iniciação científica, monitorias, receber o reconhecimento do outro, o elogio da professora, a superação dos seus limites e o resultado da prática superando o medo. Como ferramenta para acessar a qualidade de vida, 
destacam a persistência, o apoio familiar, o desempenho profissional, a força interior, o outro, a fé e a espiritualidade.

Quando estimulados a pensarem em estratégias que poderiam contribuir para melhoria da QV. enquanto estudantes de enfermagem, em processo de formação, os colaboradores destacam os seguintes aspectos, que coincidem com os pontuados no modelo ecológico adaptado para os estudantes de enfermagem, conforme segue abaixo: 


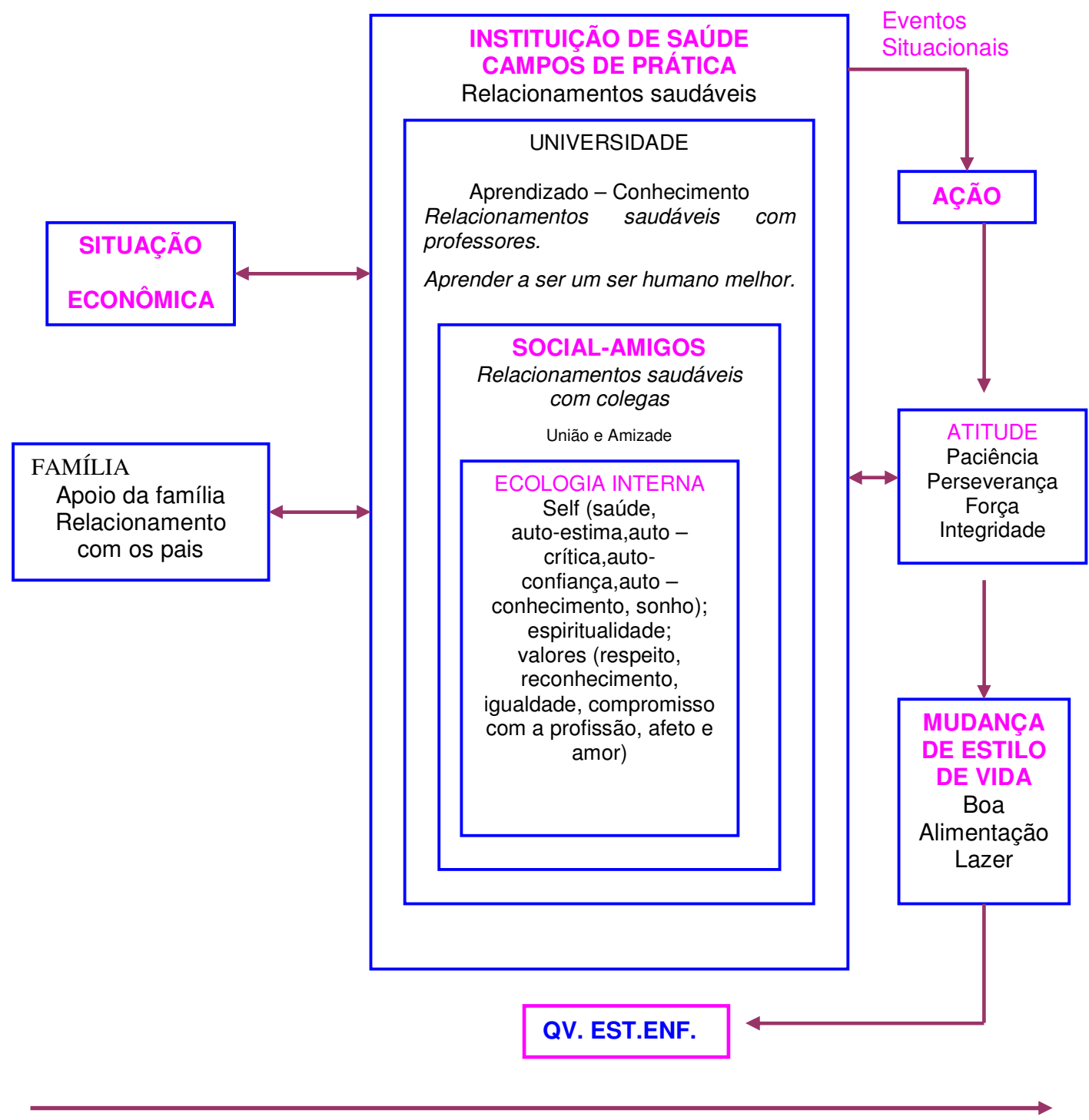

TEMPO DE FORMAÇÃO DO FUTURO ENFERMEIRO

Figura 3: $\quad$ Estratégias para melhoria da QVEst de Enf., segundo o Modelo Ecológico de QVEst. Enfermagem adaptado do proposto por Benjamin (1994)

Passaremos a analisar e comparar as estratégias indicadas

pelos alunos que poderiam contribuir para a melhoria da qualidade de vida 
enquanto estudantes de enfermagem, durante a formação, com as dimensões do Modelo Ecológico, adaptada a partir da proposta de Benjamin (1994).

Observamos que algumas das dimensões como as Instituições de Saúde (Campos de Prática); a vida social do Campus, não foram exploradas em profundidade e outras como as referentes à Universidade em sua organização e estrutura curricular (aspectos acadêmicos), não foram sequer citadas.

As dimensões citadas com maior profundidade dizem respeito às dimensões da Ecologia Interna. Isto demonstra uma necessidade de aprendizado para reconhecimento do seu mundo interno e da sua relação com o mundo externo e a elaboração de estratégias, sejam elas individuais e/ou coletivas de enfrentamento, para melhoria da QV enquanto estudantes.

Em relação à dimensão da espiritualidade, segundo Cortella (2001), a religiosidade representa um contato com o divino, é a maneira como a pessoa se conecta com o que acredita serem forças protetoras ou negativas em seu cotidiano. Essa afirmação confirma a referência dos colaboradores desta pesquisa, pois buscam, na espiritualidade, subsídios para tentar sustentar as situações percebidas como não promotoras de qualidade de vida.

Ao discutirmos a dimensão relacionada aos valores, o estudo das autoras Oliveira e Almeida (2001), na mesma Instituição, revelam os valores explicitados por alunos e professores, valores já existentes na 
profissão e na própria Universidade. Os valores citados pelos colaboradores, nesta pesquisa, (respeito, reconhecimento, igualdade, compromisso com a profissão, afeto e amor) citados pelas autoras.

Oliveira e Almeida (2001) explicam que os valores traduzem formas de aprendizagens e implicam na exploração das vivências de ensino de maneira crítica, contribuindo, assim, para o auto-conhecimento do aluno. Tal reflexão passa pela análise do papel do futuro enfermeiro, nas instituições, nas suas atividades em relação ao trabalho na equipe multiprofissional, seu posicionamento quanto as relações de poder, relações com o usuário e com sua própria saúde.

Os colaboradores apontam, com muita ênfase, que a qualidade de vida no trabalho durante a formação, assenta-se sobre a discriminação dos papéis desenvolvidos, principalmente entre alunos e professores.

Neste sentido, é necessário uma maior aproximação do professor do universo do aluno. Como professores de enfermagem, adotamos um discurso rico de integração, de humanização, de competências para o conhecer, fazer e ser, mas não nos permitimos dialogar sobre esse processo durante as vivências do aluno e tendemos a deixar de lado a dimensão do sentir. Os colaboradores deixam explicitado o quanto não lhes é permitido o sentir, pois percebem que, para ser enfermeiro, vivese ainda a contradição entre o sentir, o pensar e o agir. Entendo que estes relatos apresentados estejam "sinalizando" para que se explore esta 
contradição. É necessário tomar consciência dela e então, estabelecer estratégias de superação. Neste aspecto o professor pode ser a ponte para facilitar o aprendizado para a vida.

O aluno de enfermagem tem oportunidade, em grande parte da sua formação, de vivenciar o futuro papel profissional, porém, o estudo demonstrou que para os alunos terem a oportunidade de participar de grupos focais de elaboração da aprendizagem mostrou-se como importante e significativo .

5 5ํㅡㄹ Encontro representou a o último momento da coleta de dados E também foi utilizado para a devolutiva e avaliação dos alunos sobre o processo.

Os colaboradores quando avaliam a sua própria QV, referem que esta não está boa e pontuam a falta de auto-conhecimento, baixa autoestima, as mudança de rotina de vida e de escolhas que terão que fazer.

Os alunos demonstram de forma recorrente, o quanto lhes falta o acolhimento quanto às questões internas (os sentimentos sobre 0 vivido).

Quanto à construção da $\mathrm{QV}$, reconhecem a participação de cada um, como importante, seja individualmente ou em grupo. Percebem a QV com uma característica muito pessoal que, apesar de todos estarem empenhados, cada um terá que buscar a sua. 
Entendem que a mudança só ocorre quando há o conflito e concluem, atribuindo à Instituição e aos professores a falta de estímulo, apoio para as mudanças, para as iniciativas dos alunos, frustrando, por vezes, a continuidade dos seus projetos.

A este respeito, considero pertinente que os professores passem a valorizar e a incentivar iniciativas e participações dos alunos em projetos extra-classe. Guardam a lembrança que os alunos de enfermagem desenvolveram o grupo de Teatro (2001-2003), apresentaram a peça "Negociando com a Morte" que fez sucesso entre os alunos e vários hospitais da cidade. Outra experiência extra curricular importante que está na $3^{\text {a }}$ edição este ano, sob minha coordenação, é o Grupo Nefroriso.

Os colaboradores ao se reportarem à avaliação dos encontros grupais, durante a pesquisa, explicitaram que este favoreceu espaços continentes da expressão de si e conhecimento do outro.

Os alunos, por meio de suas falas, identificaram os encontros grupais como espaço confiável para falar de si, como sujeitos de um processo. A liberdade de poder expressar o que sentem e pensam, foi uma estratégia para levar à problematização e fazer questionamentos da realidade.

A participação do grupo foi identificada pelos alunos como um espaço de acolhimento, troca de experiências e destacaram momentos em que o grupo foi terapêutico. Esses momentos são esperados em um 
grupo operativo, apoiados na noção pichoniana, de que há aberturas para reelaboração sobre o vivido.

Os colaboradores falaram da mútua representação interna que ocorreu no grupo, isto é, aprenderam na vivência com o outro. As falas convergiram para sentimentos de gratificação.

Ao participarem do trabalho grupal, expressaram uma característica marcante que foi o compromisso assumido e mantido com a tarefa, Este compromisso foi significativo em todos os encontros.

Partindo da vivência grupal, os alunos também indicam a continuidade da aplicação do grupo em outros espaços do ambiente Universitário.

Trabalhar com grupos de uma forma produtiva requer conhecimento e preparo para essa atuação. Existem diversas técnicas e abordagens grupais, portanto, o profissional que se dispõe a trabalhar nesta direção tem de estar ciente desta diversidade, apropriar-se do conteúdo técnico-prático que mais se adeque à sua forma de ser e atuar efetivamente. 


\title{
6 A UNIVERSIDADE COMO ESPAÇO DE VIVÊNCIA DA QVEENF
}

\author{
É importante salientar que os grupos são considerados pelos \\ alunos, como um espaço que permitiu expor o que pensaram e sentiram, \\ sugerindo, criticando, mostrando-se como sujeitos ativos, participantes da \\ construção da tarefa proposta.
}

Neste cenário, o significado de QV para o estudante de enfermagem, abrange dimensões multidimensionais e deixa explícito o papel da universidade e do professor, em especial.

Este estudo permitiu identificar que existem momentos promotores de qualidade de vida dos alunos de enfermagem durante a sua formação na Universidade. Mostrou que este é um espaço onde existem os dois pólos, ou seja: situações favoráveis e desfavoráveis em relação à promoção da qualidade de vida.

As discussões nos levam a considerar que a formalização de um espaço promotor de qualidade de vida é possível e necessário. Cabenos incentivar, registrar, apontar, como se pode trabalhar com a promoção da qualidade de vida no contexto dos diferentes projetos de formação profissional nos módulos de aprendizagem e de como se pode identificar e abordar as situações que não são promotoras de qualidade de vida para o aluno. 
No que se refere às estratégias de enfrentamento para a melhoria da QV enquanto estudantes, observamos que estas são apresentadas no grupo pela somatória de estratégias individuais, provavelmente pela falta de um "modelo" de estratégias coletivas que seja internalizado pelos alunos em função de suas experiências com o grupo de professores, colegas e outros profissionais, com os quais convivem.

Os resultados desse estudo, me permitem falar em defesa da necessidade de preparo dos futuros profissionais de saúde e dos docentes para o desenvolvimento do cuidado de si, como precedente da condição para o cuidar de outros.

Isso porque, o aluno em formação vivencia no seu processo de aprendizagem, tantos os aspectos promotores como os não promotores de qualidade de vida. Posteriormente, se não há elaboração, tendem a reproduzir o mesmo modelo em suas práticas profissionais.

Costenaro e Lacerda (2002), referem que as relações de cuidado acontecem na nossa vivência diária, na família, no trabalho, no convívio social em geral. Por isso, entendem que o cuidar é uma maneira de ser de cada um incorporado a um comportamento co-participante de progressão individual e/ou coletiva aglutinados às dimensões éticas e morais.

Desta forma, as autoras enfatizam que "há que se pensar no cuidador, pois ele também precisa ser cuidado, e, neste momento, ele se 
transforma num ser cuidado, não sendo mais um ser que cuida, com todas as relações de cuidado a que tem direito."

momento presente traz à tona o grande desafio de lidar com a reforma curricular que possibilite flexibilidade de estratégias e espaços para que o estudante descubra quem é, se compreenda, promova seu crescimento e aperfeiçoamento como ser humano e futuro profissional.

Neste sentido, recomendo que algumas estratégias sejam estimuladas e introduzidas nas práticas de ensino aprendizagem, são elas:

- Aprendizagem compartilhada, ou seja, é a ocasião em que a teoria e prática estão fundamentadas no processo colaborativo de equilíbrio de poder e responsabilidade pelo aprendizado e que favorece a reciprocidade, por intermédio da comunicação e das relações interpessoais. Esta abordagem permite ao aluno transcender a frustração e a dependência do professor, propicia autonomia, um ambiente estimulador em que o aluno se sente responsável e satisfeito.

- Oportunizar vivências que minimizem o stress. Estas práticas, além de proporcionar conforto, permitem, na vivência, o aprendizado de estratégias de enfrentamento.

- Elaboração de um diário de campo,pelo aluno, onde este registre sistematicamente seus sentimentos diante das 
práticas e espaços grupais, no final dos períodos de estágio com estratégias de avaliação, que permitam aos alunos sentirem-se valorizadas pois podem contar com um espaço para verbalizar suas dúvidas e ansiedades, seus questionamentos e temores, permitindo um maior crescimento pessoal e profissional.

- Promover experiências que visem a sensibilização dos alunos quanto às relações a serem construídas com os colegas, professores e equipe de profissionais. Exercitar o respeito, os sentimentos de solidariedade, respeito e amorosidade, expressos por meio de atitudes de apreço, de consideração são fundamentais no processo de formação dos enfermeiros.

- Instituir um espaço de supervisão dos estudantes visando assistência para lidar com seus sentimentos e canalizálos para melhoria das relações que estabelecem.

- Instituir um espaço para os docentes que supra a necessidade destes para auxiliar na expressão de afetos por parte dos estudantes. A supervisão tem múltiplos propósitos e não está limitada somente aos aspectos técnicos.

Essas recomendações justificam-se pela evidência de que o contato direto com seres humanos em processo de sofrimento coloca aluno 
e professor diante de seus próprios conflitos e frustrações, sendo assim, é importante que o professor proporcione momentos de aconselhamento e escuta, de modo que o aluno possa trabalhar situações de transferência e contrareferência e assim possa elaborar as vivências que vão acontecendo no trabalho de aprender a cuidar de si e dos outros.

O aconselhamento aborda os aspectos interpessoais dos atendidos e resgata a preocupação humanizadora para com estes aos aspectos pessoais de quem atende. Para Pickering apud Martins (2001), a capacidade de aconcelhamento é importante para favorecer relações saudáveis do profissional com os clientes, o que deduz que o profissional esteja atento a sentimentos, pensamentos e comportamentos; que esteja atento ao que esteja acontencendo entre eles naquele momento e a eventos externos à relação que podem estar influenciando no que está acontecendo.

Em relação ao aspecto da escuta, Kovács (2002), aborda que essa "congruência entre quem escuta e é escutado, se refere à possibilidade do facilitador ao mesmo tempo em que ouve o outro possa estar atento aos seus próprios processos internos, no sentido de aguçar a sua sensibilidade em relação às necessidades do outro, mas não a ponto de interferir nesta escuta". Para a autora se trata de um processo de aceitação verdadeira como possibilidade efetiva; a escuta sem julgamentos ou avaliações. Não se trata de concordar e sim compreender o mais incondicional possível, por meio da empatia entendida como uma atitude, 
uma forma de ser e não uma técnica correspondendo ao colocar-se no lugar do outro "como se" estivesse no mundo dele.

Ao estudar a QVEENF., ficou evidente a importância do papel do docente, portanto, as intervenções no aprendizado da qualidade de vida dos futuros enfermeiros, passa pelo cuidado também dos docentes, pois não se pode desarticular a reprodução das situações não promotoras de QV presentes na prática do ser docente, dos diferentes contextos da situação de aprender e de ensinar.

Ciampone (1998) refere em seu estudo que o docente é tão vítima do sistema educativo como o aluno, "o docente está socializado em uma idealização do método educativo e demonstra tanta ansiedade quanto o aluno em "ter que saber, em ter que dominar o método", de modo que tende a excluir-se como pessoa da experiência da elaboração de projeto, encerrando-se em sua própria necessidade de "ter que dar conta".

A autora indica que, "fazer uma análise da opressão do aluno e do profissional em formação, sem que se faça uma análise da opressão vivida pelo docente implica em olhar apenas para uma das faces da moeda do sistema educativo".

Esslinger (2003) corrobora com esse pensamento afirmando em seu estudo, a necessidade de repensar a formação dos futuros profissionais no sentido que estes também sejam cuidados. 
A autora descreve o projeto denominado "Cuidando do Cuidador no Contexto Hospitalar" que vem sendo desenvolvido desde 1999, com a equipe de enfermagem do Hospital Universitário, relatando que as dinâmicas visam atingir os seguintes objetivos:

a) aquecimento e sensibilização para o tema principal apontado pela equipe.

b) Aprofundamento pelo tema trazido pelo grupo.

c) Planejamento da ação de cuidados ao cuidador pensada pela própria equipe de trabalho, tendo em visa suas necessidades.

Dentre as técnicas que estão sendo utilizadas nesse projeto de cuidar da equipe de enfermagem, Kovács, 2002, cita textualmente:

a) "Desconexão: com objetivo de favorecer o desligamento do mundo externo, propiciando um contato com a experiência atual.

b) Introspecção: conduzir a pessoa a um maior contato com suas vivências interiores. Esse estado é facilitado a partir de exercícios de relaxamento e sugestões de temas relacionados com o que se pretende trabalhar.

c) Relatos verbais: pede-se aos participantes que tragam o relato de experiências vividas ou daquelas acessadas na 
introspecção; permite que a pessoa ouça o que está falando, bem como, compartilhe com o grupo sua experiência, favorecendo o sentimento de pertença.

d) Atividades Expressivas: o uso dessas técnicas favorece a expressão espontânea de sentimentos e vivências, pois há um controle menor da censura consciente".

A exemplo deste Projeto, esta proposta pode ser viabilizada em outros contextos acadêmicos, integrando os alunos, os docentes e os funcionários dos campos de prática.

Ciampone (1998) declara que a proposta de ensino pautada na metodologia de grupos operativos mostrou-se eficiente no sentido de poder constituir-se em articuladora, tanto da ação docente como do profissional em formação, sem que se possa separar uma parte da outra no processo ensino-aprendizagem.

Esta proposta traz em si outros embates que só poderão surgir a partir da sua aplicabilidade. A aplicação de uma estratégia de grupo, neste estudo, mostrou-se viável como possibilidade de intervenção na realidade de ensino, sendo que, na avaliação, foram ressaltados pontos positivos de um momento vivencial onde se exercita o protagonismo.

Para viabilização desta proposta, cabe repensarmos os desafios impostos a partir de nós mesmas, dentro do contexto de trabalho 
para a construção de um processo de ensino aprendizagem, distinto daquele pelo qual fomos formadas e que estamos reproduzindo.

Conforme já foi salientado, o Curso de Enfermagem da PUC, passa pela fase de construção do seu novo projeto político pedagógico. Considero que é fundamental o reconhecimento da prática de grupos como um instrumento de intervenção e que há a necessidade da apropriação pelos docentes de conceitos e metodologias que vão além da capacitação técnica específica, das diferentes áreas do conhecimento, respeitando as respectivas especificidades. Isso atende às expectativas de formação de competências estabelecidas para a formação do futuro profissional, de forma crítica e não prescritiva.

\footnotetext{
Além de todos os aspectos que já forma pontuados, considero que experiência vivenciada no processo de doutoramento me proporcionou uma reflexão sobre o papel docente e de pesquisadora. Enfrentei o desafio de muitas vezes, desconstruir minha prática, no encontro diário com os alunos.
}

Finalizo este estudo, com o sentimento de estar transformada e de ter encontrado, o início de um processo que é contínuo, e de que me dei conta que tenho muito a fazer para transformar pois, este trabalho e tudo que nele foi construído só serve se propiciar viver a vida com melhor qualidade. 


\section{REFERÊNCIAS BIBLIOGRÁFICAS}

Almeida, L.S. et al. Dificuldades de adaptação e de realização acadêmica no Ensino Superior: Análise de acordo com as escolhas vocacionais e 0 ano de curso. Rev. Galego-Portuguesa de Psicologia e Educación, 2(2), 41-48, 1998.

Ângelo M. Vivendo uma prova de fogo: as experiências iniciais da aluna de enfermagem. [tese] São Paulo: Instituto de Psicologia da USP; 1989.

Antunes C. Como desenvolver as competências em sala de aula. Petrópolis: Vozes; 2001.

Antunes R. Adeus ao trabalho. $7^{\underline{a}}$ ed. São Paulo: Cortez. Ed. da Unicamp; 2000.

Becker $\mathrm{M}$, et al. A new patient focused index for measuring quality of live in persons with severe and persistent mental illness. Quality of life research; 1993, 2:239-251.

Benjamin M. The quality of student life: Toward a coherent conceptualization. Social Indicators Research, 31, 205-264; 1994.

Bertoni BCR. Reengenharia humana: preparando o indivíduo para a mudança. Salvador: Casa da Qualidade; 1994.

Brasil Leis. Lei n. 7498 de 25 de junho de 1986. Dispõe sobre a regulamentação do exercício da enfermagem e dá outras providências. Diário Oficial da União, Brasília, 26 de junho de 1986. Seção 1, p. 9271-5.

Brasil Leis. Lei no.2995 de 10 de dezembro de 1956. Prorroga o prazo que restringe as exigências para instruir matrícula aos curso de enfermagem nos termos do parágrafo único do artigo 5으 da Lei n.․ .775, de 06 de agosto de 1949. Enfermagem - Legislação e assuntos correlatos. 3a edição. Rio de Janeiro; GB: FSESP. v I; 1974. 
Brasil, Leis. Lei n. 9394, de 20 de dezembro de 1996. Estabelece as diretrizes e bases da educação nacional. Diário Oficial da República Federativa do Brasil, Brasília (DF), n²48, dez. 1996. p. 27.833-27.841.

Brasil. Portaria n. 1721 de 15 de dezembro de 1994. Fixa os mínimos de conteúdo e duração do curso de graduação em Enfermagem. Diário Oficial da República Federativa do Brasil, Brasília, 16 de dezembro de 1994, seção 1 .

Brasil. Resolução n. -3 de 7 de novembro de 2001. Institui Diretrizes Curriculares Nacionais do curso de graduação em Enfermagem. Conselho Nacional de Educação [online]. Brasília; 2001. Disponível em http://www.in.gov.br (09 de nov. de 2001).

Breilh, J. ; Granda, E. Investigação da saúde na sociedade: guia pedagógico sobre um novo enfoque do método epidemiológico. São Paulo, Instituto de Saúde - ABRASCO, 1986

Carandina, DM. Qualidade de Vida no Trabalho: construção e validação de um instrumento de medida para enfermeiras. [Tese] São Paulo: Escola de Enfermagem da USP, 2003

Caldeira V. da P. Estágio extracurricular em Enfermagem, opção ou obrigação? Uma condição a ser superada. Rev. Min. Enf.; 1997;1 (1): 36-41.

Cavalcante, MB. Humanização no processo de formação de profissionais de saúde: experiências de alunos do curso de graduação de Enfermagem. [Tese] São Paulo: Escola de Enfermagem da USP; 2003.

Carvalho, MB. O trabalho de enfermagem psiquiátrica e os problemas de saúde dos trabalhadores. [Dissertação] São Paulo: Escola de Enfermagem da USP; 2004.

Chiavenato I. Introdução a teoria geral da administração. 6aㅗ edição. Rio de Janeiro: Campus; 2000.

Costenaro, RGS; Lacerda, MR. Quem cuida de quem cuida? Quem cuida do cuidador? $2^{\mathrm{a}}$ ed. Santa Maria, Centro Universitário; 2002. 
Chiesa AM, Ciampone MHT. Princípios gerais para a abordagem de variáveis qualitativas e o emprego da metodologia de grupos focais. Associação Brasileira de Enfermagem, In: Classificação Internacional das práticas de enfermagem em saúde coletiva - Série Didática, Brasília; 1999. (no prelo).

Ciampone MHT, D’Agnoll C. Grupos focais como estratégia metodológica em pesquisas na enfermagem. Rev. Gaúcha de Enferm.; 1999. 20 (1):5-25.

Ciampone MHT. Grupo Operativo: construíndo bases para o ensino e a prática na enfermagem. [tese] São Paulo (SP): Escola de Enfermagem da USP; 1998.

Estivalet E. de L. Cuidando do Cuidador em processo de formação: vivendo uma experiência no âmbito do ensino da Graduação em Enfermagem. São Paulo: Relatório de Pesquisa. 2000. (Mimeografado).

- Grupo operativo: construindo bases para o ensino e a prática na enfermagem. tese [Livre Docência] São Paulo: Escola de Enfermagem da USP; 1998.

Cortela, MS. Religião: um povo que acredita. [Entrevista a Jaime Klintowitz] Veja 2001 dez 19: 127

Davis K, Werther WB. Administração de pessoal e recursos humanos. São Paulo: McGraw-Hill; 1983.

Demo P. Educação e Qualidade. $3^{\mathrm{a}}$ ed. Campinas: Papirus; 1996.

Domingues, I. O sentir e a indisciplina: uma reflexão sobre a qualidade de vida no cotidiano de alunos/futuros profissionais de Administração. Rev. Gruppo; Ed. Especial de Aniversário; 2005.

Esslinger, I. O paciente, a equipe de saúde e o cuidador; de quem é a vida, afinal? - Um estudo acerca do morrer com dignidade. [Tese] São Paulo (SP): Departamento de Psicologia da Aprendizagem, do Desenvolvimento e da Personalidade; 2003 
Felli,V. E. A. A saúde do trabalhador e o gerenciamento em enfermagem. Tese (Livre Docência)São Paulo(SP): Escola de Enfermagem da USP. 2002

Fernandes EC. Qualidade de Vida no trabalho: como medir para melhorar. Salvador: Casa da Qualidade; 1996.

Flanagan JC. Measurement of Quality of life: current state of the art.: Arch Phys Med Rehabil; 1982, $63:$ 56-9

Fleck MPA, Leal OF, Louzada S, Xavier M, Chachamovich E, Vieira G. et al. Desenvolvimento da versão em português do instrumento de avaliação de qualidade de vida da OMS (WHOQOL-100). Rev. Brasileira de Psiquiatria, São Paulo; 1999; 21 (1).

Freire, P. Pedagogia do oprimido. Rio de Janeiro: Paz e Terra; 1975

Gaíva MAM. Qualidade de Vida e Saúde. Rev. Enferm. UERJ, Rio de Janeiro; 1998; 6 (2).

Gardenal CLC. Da História às Falas dos Egressos: Currículo de Enfermagem - Um outro olhar. [Mestrado] São Paulo: Educação: Supervisão e Currículo: PUC-SP; 1996.

Germano RM. Educação e ideologia da enfermagem. 2ª edição. São Paulo: Cortez; 1985.

Goodinson SM, Singleton J. Quality of life; a critical review of current concept measures and their clinical implications. Internacional Journal of nursing Saudies;1989; 26 (4): 327-341.

Gutierrez, BAO. O processo de morrer no cotidiano do trabalho dos profissionais de enfermagem de unidades de terapia intensiva. [Tese] São Paulo (SP): Escola de Enfermagem da USP; 2003

Haddad MCL. Qualidade de vida dos profissionais de enfermagem. [online]. Disponível em: http://www.ccs.br/espacoparasaude/v1n2/doc/artigos2 (16 abr. 2002).

Herzberg F. The motivation: hygiene concess and problems of manpower. Person Adm 1964. 27 (1): 3-7 
. One more time: how do you motivate employees? Havard Bus Rev. 1968; 46 (1): 53-62

Iglesias, RB. Qualidade de Vida de alunos-trabalhadores que cursam a graduação em enfermagem. [Dissertação]. São Paulo (SP): Escola de Enfermagem da USP; 2002.

Kawakame, PMG; Miyadahira, AMK. Qualidade de vida em estudantes de graduação em enfermagem. Rev. Escola de Enfer. da USP, 2005.39 (2)|: 164-72

Kovács MJ. Educação para a morte: um desafio para a formação de profissionais de saúde e educação. Dissertação [Livre-Docência]. São Paulo (SP): Instituto de Psicologia, USP; 2002

Leitão, R. E. R. A qualidade nos serviços de enfermagem segundo a percepção de enfermeiras que vivenciam essa prática. Tese [Doutorado]. São Paulo, (SP): Escola de Enfermagem da Universidade de São Paulo, USP;2002.

Lentz RA, Costernaro RGS, Gonçalves LHT, Nassar SN. O profissional de enfermagem e a qualidade de vida: uma abordagem fundamentada nas dimensões propostas por Flanagan. Rev. Latino Americana de Enfermagem. Ribeirão Preto; 2000, 8 (4): 7-14.

Limongi-França AC, Rodrigues AL. Stress e trabalho: uma abordagem psicossomática. $2^{\mathrm{a}}$ ed. São Paulo: Atlas; 1999.

Interfaces da qualidade de vida no trabalho na administração de empresas: fatores críticos na gestão empresarial para uma nova competência. [livre docência]. São Paulo (SP): Faculdade de Economia, Administração e Contabilidade da USP; 2001.

Lino, MM. Qualidade de vida e satisfação profissional de enfermeiras de unidades de terapia intensiva. [Tese] São Paulo (SP): Escola de Enfermagem da USP; 2004.

Ludke M, A MEDA. Pesquisas em educação. Abordagem qualitativa. São Paulo. Epu; 1986. 
Martins, MCFN. Humanização das relações assistenciais: a formação dos profissionais de saúde. São Paulo: Casa do Psicólogo; 2001.

Matos E. Refletindo sobre a qualidade de vida no trabalho da Enfermagem no Hospital Universitário. Texto \& Contexto;1999. 3 (3):27-43.

McGregor D. O lado humano da empresa. São Paulo: Martins Fontes; 1980.

Mendes AC. Stress e Imunidade: contribuições para o estudo dos factores pessoais nas alterações imunitária relacionadas com o stress. Coimbra. Formasau; 2002

Menzies I. The functioning of organizations as social sistems of defence aganist anxietie. Londres: Travestock Institute of Human ons; 1970.

Mercuri, ENG. Condições espaciais, materiais, temporais e pessoais para o estudo segundo depoimento de alunos e professores do curso de graduação da Unicamp. Campinas - SP. Tese (Doutorado) Universidade Estadual de Campinas, 1992.

Minayo MCS, Hartz ZMA, Buss PM. Qualidade de vida e saúde: um debate necessário. Ciência \& Saúde. São Paulo; 2000, 5 (1) :7-18.

. O Desafio do Conhecimento: pesquisa qualitativa em saúde. São Paulo. Rio de Janeiro, Hucitec; 1996.

Ministério da Saúde Conselho Nacional de Saúde. Resolução n.196 de 10 de outubro de 1996. Diretrizes e normas regulamentadoras de pesquisa em seres humanos. Mundo Saúde 1996; 21:52-61

Fundação Serviços de Saúde Pública. Enfermagem, legislação e assuntos correlatos. 3aㅡ edição. Rio de Janeiro; 1974. 3ํv.

Moreira WW.(org.) Qualidade de Vida: complexidade e educação. Campinas: Papirus; 2001. 
Nico JB. O conforto acadêmico do(a) calouro(a). In Ana Paula Soares. et al. (org.) Transição para o ensino superior. Edição: Universidade do Minho. Braga; 2000.

Oliveira, RA; Almeida, JM Desvelando valores dentro do universo da formação dos enfermeiros da PUC-SP. Resumos do Congresso Internacional Valores Universais e o futuro da sociedade. São Paulo, setembro de 2001. p. 47

Oliveira, JAC. Qualidade de vida em estudantes universitários em Educação Física. Dissertação de mestrado. Campinas - SP. Universidade Estadual de Campinas, 1998.

Oliveira ICD, Fernandes JF, Lunardi VL. Como a futura enfermeira está se cuidando e vem sendo cuidada no processo de graduação. Rev. Texto e Contexto Enferm.: 2000; 9 (3): 133-152.

Pascarella ETE, Terenzini PT, How College Affects Students: Findings and Insights from Thirty Years of Research. San Francisco: Jossey-Bass; 1991.

Peña, G, Shirley, J. O âmago de um espinho adormecido : análise da gestão de qualidade de vida no trabalho em um hospital psiquiátrico público. São Paulo Dissertação [Mestrado] - Escola de Enfermagem. Universidade de São Paulo. 2000.

Pessoa, F. O guardador de rebanhos. In Poemas; seleção e introdução de Cleonice Berardinell. Rio de Janeiro (RJ): Nova Fronteira, 1985, p. 66

Pichon-Rivière E. O processo grupal. Trad. por Marco Aurélio Fernandes Velosso. $6^{a}$ ed. São Paulo: Martins Fontes, 2000.

Teoria do Vínculo. Trad. Eliane Toscano Zamikhouwsky. $6^{a}$ ed. São Paulo: Martins Fontes, 2000.

Pires D. Hegemonia médica na saúde e a enfermagem. Brasil: 1500-1930, São Paulo: Cortez; 1989. 156 p. 
Polydoro, SAJ. O trancamento de matrícula na trajetória acadêmica do universitário : condições de saída e de retorno à instituição. Tese [doutorado]. Campinas - SP, Universidade Estadual de Campinas, 2001.

Rocha, SSL. Qualidade de vida no trabalho em enfermagem : percepção de enfermeiros docentes de uma universidade privada. [Tese] São Paulo: Escola de Enfermagem da USP; 2002

Rodrigues, MVC. Qualidade de vida no trabalho: evolução e análise no nível gerencial. $2^{\mathrm{a}}$ ed. Petrópolis: Vozes, 1994.

Quirino T, Xavier O. Qualidade de vida no trabalho de organização de pesquisas. Rev. Adm Empresa 1987; 22 (1): 72-81

Santomé JT. Globalização e Interdisciplinariedade: O currículo integrado. Porto Alegre: Artes Médicas; 1998.

Santos, S.M. As responsabilidades da Universidade no acesso ao Ensino Superior. In Ana Paula Soares et al (ed.) Transição para o ensino superior. Braga, Universidade do Minho, 2001.

Saupe R; ALVES, ED. Contribuição à construção de Projetos PolíticoPedagógicos na Enfermagem. Revista Latino-Americana de Enfermagem, Ribeirão Preto - SP, v. 8, n. 2, p. 62, abril 2000.

Saupe R. Qualidade de vida dos acadêmicos de enfermagem. Resumos do terceiro encontro da lista de pesquisadores em qualidade de vida. São Paulo. USP, dezembro de 2002.

Seixas R. Tente Outra Vez. In As Profecias; Faixa 12. [Compact Disc] WEA; 1991.

Schmidt, DRC. Qualidade de vida e qualidade de vida no trabalho de profissionais de enfermagem atuantes em unidades do bloco cirúrgico. [Dissertação] Ribeirão Preto (SP): Escola de Enfermagem da USP; 2004

Shimizu HE. As representações sociais dos trabalhadores de Enfermagem não enfermeiros (Técnicos e Auxiliares de Enfermagem) sobre o trabalho em Unidade de Terapia Intensiva em um Hospital - Escola. [Tese] São Paulo: Escola de Enfermagem da USP; 2000. 
Silva, CM et al Pesquisa em enfermagem: importância e sua evolução no Brasil. Acta Paulista de Enfermagem, São Paulo, v 4, n 1, p 34-38, mar. 1991.

Silva VEF, Massarollo MCB. A qualidade de vida e a saúde do trabalhador de enfermagem. O Mundo da Saúde. São Paulo; 1998, 22 (5): 283-286.

Souza, T.M. O gerenciamento no cotidiano de uma unidade de terapia intensiva pediátrica e neonatal e a qualidade de vida no trabalho da equipe de enfermagem. [Dissertação] São Paulo (SP):Escola de Enfermagem da USP;2003.

Vieira DFVB, Hanashiro DMM. Visão introdutória de qualidade de vida no trabalho. Rev. Gaúcha de Enfermagem. Porto Alegre; 1990. 11 (2):41-46.

Walton RE. Quality of working life: what is it? Slon Manage Rev 1973; 15 (1): $11-21$

Waldow, V.R. Cuidado Humano: o resgate necessário. Porto Alegre: Sagra, 1998 
ANEXO 1

COMITE de ETICA 


\author{
ANEXO 2 \\ SOLICITAÇÃO DE AUTORIZAÇÃO PARA A PESQUISA \\ Ilma. Sra. \\ MS. Eliana de Paula Leite \\ Chefe do Departamento de Enfermagem
}

\title{
Prezada Senhora,
}

Eu, Raquel Aparecida de Oliveira, portadora do RG 15.752.398, enfermeira, COREN-49429, docente do Departamento de Enfermagem, do Centro de Ciências Médicas e Biológicas da Pontifícia Universidade Católica de São Paulo, aluna regularmente matriculada no Programa de PósGraduação Inter - Unidades, nível doutorado, da Escola de Enfermagem, da Universidade de São Paulo e Ribeirão Preto, venho por meio deste solicitar a Vossa Senhoria autorização para a coleta de dados para a minha Tese de Doutorado.

Cabe esclarecer que a participação dos alunos será voluntária e o mesmo ocorrerá, após consentimento livre e esclarecido dos mesmos.

Em anexo, segue uma cópia do Projeto de Pesquisa.

Antecipadamente agradeço. 


\section{ANEXO 3}

\section{ROTEIRO PARA ENTREVISTA INDIVIDUAL}

1) Para você o que é ter qualidade de vida no trabalho?

2) Relate uma situação vivida ou observada onde você percebeu condições promotoras da qualidade de vida.

3) Relate uma situação vivida ou observada onde você percebeu condições promotoras da qualidade de vida. 


\section{ANEXO 4}

\section{CARTA DE INFORMAÇÃO ${ }^{2}$ \\ (PARTICIPAÇÃO DAS ENTREVISTAS)}

Contando com a sua colaboração em participar da pesquisa intitulada: "Na Universidade Aprende-se Qualidade de Vida?", de minha autoria, dirijo-me, no intuito de obter seu consentimento formal para proceder à entrevista individual, a ser gravada em áudio.

O principal objetivo a que me proponho, neste estudo, é conhecer as representações que o aluno têm sobre a sua qualidade de vida, tendo em vista as experiências vivenciadas no processo de formação.

Nesta fase, através de entrevista individual, gravada em áudio, busco conhecer o que é ter qualidade de vida no trabalho para você e no relato de duas situações vivenciadas ou observadas, como você percebeu as condições promotoras da qualidade de vida e a as condições não promotoras da qualidade de vida. Numa fase subseqüente às entrevistas, ocorrerão as sessões grupais entre os participantes que quiserem participar com o propósito de dialogar sobre os principais temas gerados nas entrevistas e direcionar estratégias que impactem na melhoria da qualidade de vida do enfermeiro em formação.

Esclareço que esta pesquisa faz parte da minha formação acadêmica no Curso de Doutorado em Enfermagem do Programa InterUnidades da EE-USP-RP assim, é totalmente isenta de vinculações hierárquicas e administrativas ou de influências que possam interferir no seu vínculo como aluno na instituição. Afasto, portanto quaisquer pressuposições

${ }^{2}$ Documento feito em duas vias (uma para o participante e outra para a pesquisadora) 
de natureza coercitiva em decorrência de sua participação na pesquisa, bem como por ocasião do relatório acadêmico da tese de doutoramento.

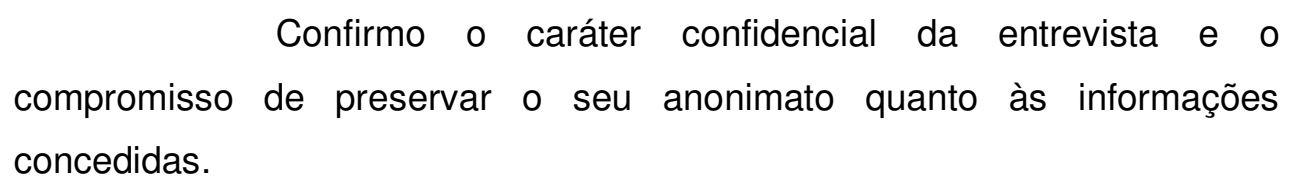
concedidas.

Fica, também assegurada a liberdade de optar pelo ingresso e continuidade no estudo ou pela desistência, a qualquer momento, sem que sua tomada de decisão incorra em prejuízos para você.

Como pesquisadora responsável por este Projeto, coloco-me à disposição para esclarecimentos adicionais que se fizerem necessários, mesmo após a entrevista.

\section{TERMO DE CONSENTIMENTO LIVRE E ESCLARECIDO}

Eu, abaixo assinado, li e compreendi as informações acima, não tendo dúvidas a respeito. Aceito participar voluntariamente neste estudo.

Data: 103

Nome do aluno por extenso:

Assinatura do Aluno

Pesquisadora Responsável: Raquel Aparecida de Oliveira.

Assinatura:

Rua Visconde de Cairu, 694. Ap. 31 Bc 04

Mangal - Sorocaba - SP Fone (15) 9116-1109

Sorocaba, de 2003. 


\section{ANEXO 5 \\ CARTA DE INFORMAÇÃO \\ (PARTICIPAÇÃO NOS GRUPOS FOCAIS)}

Em continuidade à pesquisa que versa sobre qualidade de vida do enfermeiro em formação, no intuito de obter seu consentimento como participante nas atividades de Grupos Focais.

O principal objetivo a que me proponho, neste estudo, é conhecer as representações acerca da qualidade de vida dos enfermeiros em formação.

A primeira fase da pesquisa consistiu em entrevistas individuais. Nesta fase, a proposta é de realizar sessões grupais entre os participantes, sob minha coordenação, para que se possa dialogar sobre os aspectos mais significativos sobre os temas emergentes das entrevistas individuais e delinear propostas de intervenções da melhoria da qualidade de vida do enfermeiro em formação. Nas sessões haverá a presença de um observador, que fará anotações de todo o processo durante as atividades grupais. As sessões serão gravadas em áudio para viabilizar uma retomada fidedigna quanto aos eixos de discussões. Todo o produto das atividades, como por exemplo, desenhos, relatos, etc, farão parte do objeto de análise.

No primeiro encontro será discutido um contrato grupal com os participantes sobre as seguintes cláusulas: Horários e duração das sessões; atrasos e faltas; desistência do participante; sigilo compartilhado; dinâmica do debate, o setting, que é o momento ideal para esclarecer sobre a dinâmica grupal, combinando como serão feitos os relatos, as intervenções, as complementasses, enfim o diálogo construído.

\footnotetext{
${ }^{3}$ Documento feito em duas vias (uma para o participante e outra para a pesquisadora)
} 
Esta pesquisa esta pesquisa faz parte da minha formação acadêmica no Curso de Doutorado em Enfermagem Inter-Unidades da EEUSP-RP, assim, é totalmente isenta de vinculações hierárquicas e administrativas ou de influências que possam interferir no seu vínculo como aluno na instituição. Afasto, portanto quaisquer pressuposições de natureza coercitiva em decorrência de sua participação na pesquisa, bem como por ocasião do relatório acadêmico da tese de doutoramento.

Confirmo o caráter confidencial das questões colocadas em grupo e o compromisso de preservar o seu anonimato quanto às informações concedidas no transcorrer das atividades e, por ocasião da análise dos resultados que contarão no relatório de tese.

Fica, também assegurada a liberdade de optar pelo ingresso e continuidade no estudo ou pela desistência, respeitando o contrato grupal, a qualquer momento, sem que sua tomada de decisão incorra em prejuízos para você e para o grupo.

Como pesquisadora responsável por deste Projeto, colocome à disposição para esclarecimentos adicionais que se fizerem necessários, mesmo após a entrevista.

\section{TERMO DE CONSENTIMENTO LIVRE E ESCLARECIDO}

Eu, abaixo assinado, li e compreendi as informações acima, não tendo dúvidas a respeito. Aceito participar voluntariamente neste estudo. Nome do aluno por extenso:

Assinatura do Aluno:

Pesquisadora Responsável: Raquel Aparecida de Oliveira.

Assinatura:

Rua Visconde de Cairu, 694. Ap. 31 Bc 04

Mangal - Sorocaba - SP Fone (15) 9116-1109

Sorocaba, de 2003. 


\section{ANEXO 6}

\section{QUADRO DAS PALAVRAS E CHAVES ÍNDICES Entrevista 1}

\section{Significados de qualidade de vida.}

\begin{tabular}{|c|c|c|}
\hline CATEGORIAS / FALAS & PALAVRAS FRASES ÍNDICES & $\begin{array}{c}\text { INTERPRETAÇÃO DO } \\
\text { PESQUISADOR }\end{array}$ \\
\hline $\begin{array}{l}\text { Ter qualidade de vida no trabalho } \\
\text { significa em primeiro lugar a pessoa ter } \\
\text { que gostar do que faz, se ela não } \\
\text { gosta, ela não vai ter vontade de } \\
\text { fazer o trabalho, vai fazer só por } \\
\text { obrigação, pelo dinheiro, ou por outra } \\
\text { coisa, se ela gosta do que faz ela vai } \\
\text { se sentir melhor }\end{array}$ & $\begin{array}{l}\text {... a pessoa ter que gostar do que } \\
\text { faz, se ela não gosta, ela não vai } \\
\text { ter vontade de fazer o trabalho... } \\
\text { se ela gosta do que faz ela vai } \\
\text { se sentir melhor... }\end{array}$ & $\begin{array}{l}\text { Afirma que a qualidade de } \\
\text { vida está relacionada a } \\
\text { gostar do que faz. } \\
\text { Se faz o que gosta vai se } \\
\text { sentir melhor. }\end{array}$ \\
\hline $\begin{array}{l}\text {... Por mais que ela goste do trabalho, } \\
\text { ela não pode pensar só no trabalho ela } \\
\text { tem que ter um tempo para se } \\
\text { divertir, passear, namorar, curtir o } \\
\text { filho, o marido, tem que ter a vida } \\
\text { pessoal, ela não pode exclusivamente } \\
\text { se fechar só no trabalho, trabalho... }\end{array}$ & $\begin{array}{l}\text {...tem que ter um tempo para } \\
\text { se divertir, passear, namorar, } \\
\text { curtir o filho, o marido, tem } \\
\text { que ter a vida pessoal, }\end{array}$ & $\begin{array}{l}\text { Refere a necessidade de ter } \\
\text { equilíbrio entre a vida } \\
\text { profissional e pessoal. Não } \\
\text { viver só em função do } \\
\text { trabalho. }\end{array}$ \\
\hline $\begin{array}{l}\text { Eu acho que qualidade de vida no } \\
\text { trabalho é você poder trabalhar, sei } \\
\text { lá um horário de } 8 \text { horas por dia ou } \\
12 \text { horas por } 36, \text { não pegar } 3 \text { ou } 4 \\
\text { empregos, acho não é por aí, tem } \\
\text { gente que tem. Que qualidade de vida } \\
\text { esta pessoa tem, não tem tempo para } \\
\text { os filhos, para o marido, não vê a } \\
\text { família, não se vê. }\end{array}$ & $\begin{array}{l}\text { Eu acho que qualidade de vida } \\
\text { no trabalho é você poder } \\
\text { trabalhar, sei lá um horário de } \\
8 \text { horas por dia ou } 12 \text { horas } \\
\text { por } 36 \text {, não pegar } 3 \text { ou } 4 \\
\text { empregos... }\end{array}$ & $\begin{array}{l}\text { Relaciona qualidade de vida } \\
\text { com a carga horária de } \\
\text { trabalho e a sobrecarga de } \\
\text { acúmulo de mais de um } \\
\text { emprego. }\end{array}$ \\
\hline CATEGORIAS / FALAS & PALAVRAS FRASES ÍNDICES & $\begin{array}{c}\text { INTERPRETAÇÃO DO } \\
\text { PESQUISADOR }\end{array}$ \\
\hline $\begin{array}{l}\text { Tem que ter qualidade de vida de que } \\
\text { adianta, você querer pensar nos outros } \\
\text { cuidar do outro, você é uma pessoa, } \\
\text { você não é uma máquina, como } \\
\text { preocupar-se com outra pessoa, cuidar } \\
\text { das pessoas se comigo mesma eu não } \\
\text { faço, como eu vou fazer bem para outra } \\
\text { pessoa, eu vou fazer terapia.... risos.... }\end{array}$ & $\begin{array}{l}\text { como preocupar-se com outra } \\
\text { pessoa, cuidar das pessoas se } \\
\text { comigo mesma eu não faço, } \\
\text { como eu vou fazer bem para } \\
\text { outra pessoa, eu vou fazer } \\
\text { terapia.... risos... }\end{array}$ & $\begin{array}{l}\text { Considera que para ter } \\
\text { qualidade de vida e cuidar } \\
\text { do outro, precisa também } \\
\text { cuidar-se. }\end{array}$ \\
\hline
\end{tabular}

Situações promotoras de qualidade de vida.

\begin{tabular}{|c|c|c|}
\hline CATEGORIAS / FALAS & PALAVRAS FRASES ÍNDICES & $\begin{array}{c}\text { INTERPRETAÇÃO DO } \\
\text { PESQUISADOR }\end{array}$ \\
\hline $\begin{array}{l}\text { Uma situação que foi legal, um } \\
\text { trabalho que a gente fez com a Prof.a. } \\
\mathrm{X} \text {, que a gente falou sobre auto estima, } \\
\text { dois trabalhos, a gente trabalhou } \\
\text { com as mães da creche. }\end{array}$ & $\begin{array}{l}\text {...um trabalho que a gente fez } \\
\text { com a Prof.a. X, que a gente } \\
\text { falou sobre auto estima }\end{array}$ & $\begin{array}{l}\text { Relata a atividade } \\
\text { acadêmica como algo } \\
\text { prazeiroso }\end{array}$ \\
\hline $\begin{array}{l}\text { Tinha um monte de coisas, na aula de } \\
\text { psiquiatria, a profa. sempre fala que } \\
\text { precisa cuidar da mente...eu estava } \\
\text { muito estressada, não estava } \\
\text { agüentando mais não via a hora de ir } \\
\text { embora, e assim isto tudo me ajudou } \\
\text { muito, a pensar em mim, a falar o } \\
\text { que eu penso e buscar o que eu } \\
\text { quero mesmo. Mudei bastante. }\end{array}$ & $\begin{array}{l}\text {...na aula de psiquiatria, a } \\
\text { profa. sempre fala que precisa } \\
\text { cuidar da mente...eu estava } \\
\text { muito estressada. } \\
\\
\text {...isto tudo me ajudou muito, a } \\
\text { pensar em mim, a falar o que } \\
\text { eu penso e buscar o que eu } \\
\text { quero mesmo. Mudei bastante. }\end{array}$ & $\begin{array}{l}\text { Correlaciona o aprendizado } \\
\text { teórico com sua vivência. } \\
\text { Confirma o quanto o } \\
\text { aprendizado a ajudou a a } \\
\text { pensar e buscar o que quer } \\
\text { e na sua mudança pessoal. }\end{array}$ \\
\hline
\end{tabular}




\begin{tabular}{|c|c|c|}
\hline $\begin{array}{l}\text { Uma aula que me ajudou muito foi } \\
\text { antropologia, eu nunca tinha parado } \\
\text { para pensar a questão da cultura...e } \\
\text { eu senti na pele isto, eu tive um } \\
\text { impacto, muita coisa bateu de frente } \\
\text { comigo. Aprendi a compreender mais } \\
\text { as pessoas, até com o paciente... Pra } \\
\text { mim valeu muito, muita coisa que eu } \\
\text { não entendia, pude compreender, } \\
\text { pra mim mesma. }\end{array}$ & $\begin{array}{l}\text { Uma aula que me ajudou muito } \\
\text { foi antropologia, eu nunca tinha } \\
\text { parado para pensar a questão da } \\
\text { cultura. } \\
\text { Aprendi a compreender mais as } \\
\text { pessoas, até com o paciente... } \\
\text { muita coisa que eu não } \\
\text { entendia, pude compreender, } \\
\text { pra mim mesma. }\end{array}$ & $\begin{array}{l}\text { Considera a Disciplina de } \\
\text { Antropologia facilitadora } \\
\text { para a sua compreensão de } \\
\text { outras pessoas e de sí } \\
\text { mesma. }\end{array}$ \\
\hline
\end{tabular}

Situações não promotoras de qualidade de vida.

\begin{tabular}{|c|c|c|}
\hline CATEGORIAS / FALAS & PALAVRAS FRASES ÍNDICES & $\begin{array}{c}\text { INTERPRETAÇÃO DO } \\
\text { PESQUISADOR }\end{array}$ \\
\hline $\begin{array}{l}\text { Ah!! Os estágios, né. No primeiro ano } \\
\text { nossa!! O medo da Profa. Z que pelo } \\
\text { amor de Deus!!! Então no começo foi } \\
\text { muito difícil, eu não sei, eu acho que se } \\
\text { a disciplina não tivesse tanto } \\
\text { procedimento, deveria ter mais } \\
\text { sensibilidade, eu tinha muito medo } \\
\text { de fazer um procedimento errado, de } \\
\text { ter uma reclamação da professora, } \\
\text { então eu sentia muito medo de } \\
\text { chegar. Talvez se fosse de outra forma } \\
\text { eu teria aproveitado mais os estágios, } \\
\text { eu ficava com medo mesmo, a } \\
\text { disciplina me agonizava muito eu } \\
\text { ficava com muito medo, me } \\
\text { estresso, sabe, eu tinha medo, mas } \\
\text { assim, o bom é que eu não desisti da } \\
\text { nrofissão }\end{array}$ & $\begin{array}{l}\text { que se a disciplina não tivesse } \\
\text { tanto procedimento, deveria ter } \\
\text { mais sensibilidade, eu tinha } \\
\text { muito medo de fazer um } \\
\text { procedimento errado, de ter uma } \\
\text { reclamação da professora, então } \\
\text { eu sentia muito medo de chegar. } \\
\text { eu ficava com medo mesmo, a } \\
\text { disciplina me agonizava muito } \\
\text { eu ficava com muito medo, me } \\
\text { estresso. eu tinha medo, mas } \\
\text { assim, o bom é que eu não } \\
\text { desisti da profissão. }\end{array}$ & $\begin{array}{l}\text { Considera a introdução no } \\
\text { hospital, o medo da } \\
\text { professora, o número de } \\
\text { procedimentos e a falta de } \\
\text { sensibilidade, e a possível } \\
\text { repreensão do professor } \\
\text { diante de erros, geradores } \\
\text { de muito medo de se } \\
\text { colocar. } \\
\text { Aponta a disciplina geradora } \\
\text { de muito medo e de seu } \\
\text { estress. Relata o desejo de } \\
\text { desistir, mas que é superado } \\
\text { pelo querer fazer } \\
\text { enfermagem. }\end{array}$ \\
\hline
\end{tabular}

Significados de qualidade de vida.

\begin{tabular}{|l|l|l|}
\hline \multicolumn{1}{|c|}{ CATEGORIAS / FALAS } & PALAVRAS FRASES ÍNDICES & \multicolumn{1}{|c|}{$\begin{array}{c}\text { INTERPRETAÇÃO DO } \\
\text { PESQUISADOR }\end{array}$} \\
\hline $\begin{array}{l}\text { Porque qualidade de vida é isto, não } \\
\text { viver só em função do trabalho, você } \\
\text { não pode se sobrecarregar, não pode } \\
\text { se estressar, e eu acho que para evitar }\end{array}$ & $\begin{array}{l}\text { não viver só em função do } \\
\text { trabalho, você não pode se } \\
\text { isto, precisa ter uma atividade } \\
\text { terapêutica, ter família, apoio } \\
\text { psicológico, em todos, mas eu acho } \\
\text { que é muito preciso, ter uma religião, } \\
\text { estressar, e eu acho que para } \\
\text { evitar isto, precisa ter uma } \\
\text { atividade terapêutica, ter } \\
\text { família, apoio psicológico, em } \\
\text { todos, mas eu acho que é } \\
\text { muito preciso, ter uma religião, } \\
\text { uma fé. }\end{array}$ & $\begin{array}{l}\text { Chama a atença } \\
\text { necessidade de um respaldo, } \\
\text { um apoio psicológico e de } \\
\text { atividade terapêutica, ter } \\
\text { família, ter religião, ter fé, } \\
\text { bem como a necessidade de } \\
\text { não viver só em função do } \\
\text { trabalho. }\end{array}$ \\
\hline
\end{tabular}

Situações promotoras de qualidade de vida.

\begin{tabular}{|c|c|c|}
\hline CATEGORIAS / FALAS & PALAVRAS FRASES ÍNDICES & $\begin{array}{c}\text { INTERPRETAÇÃO DO } \\
\text { PESQUISADOR }\end{array}$ \\
\hline $\begin{array}{l}\text { Em alguns estágios, não todos, eu } \\
\text { vi muita gente trabalhando com } \\
\text { gosto, alguns professores também. } \\
\text { Você percebe que eles tentam passar } \\
\text { segurança e que eles entendem seus } \\
\text { problemas, e que eles procuram dar } \\
\text { um certo apoio e eu acho que isto } \\
\text { ajuda bastante }\end{array}$ & $\begin{array}{l}\text { Você percebe que eles tentam } \\
\text { passar segurança e que eles } \\
\text { entendem seus problemas, e } \\
\text { que eles procuram dar um } \\
\text { certo apoio e eu acho que isto } \\
\text { ajuda bastante. }\end{array}$ & $\begin{array}{l}\text { Revela que a postura de } \\
\text { acolhimento de pessoas e } \\
\text { professores em alguns } \\
\text { estágios ajudam bastante. }\end{array}$ \\
\hline $\begin{array}{l}\text { Sei lá alguns trabalhos que a } \\
\text { faculdade faz, a Semana da } \\
\text { Enfermagem, que trata um pouco da } \\
\text { parte psicológica, que fala da } \\
\text { humanização, acho que isto abre um } \\
\text { pouco a nossa cabeça também. } \\
\text { Algumas matérias também, } \\
\text { psicologia, antropologia, que fazem }\end{array}$ & $\begin{array}{l}\text {...alguns trabalhos que a } \\
\text { faculdade faz, a Semana da } \\
\text { Enfermagem, que trata um pouco } \\
\text { da parte psicológica, que fala da } \\
\text { humanização, acho que isto abre } \\
\text { um pouco a nossa cabeça } \\
\text { também. } \\
\text { matérias também, psicologia, }\end{array}$ & $\begin{array}{l}\text { Refere que atividades } \\
\text { promovidas pela } \\
\text { universidade ( Semana de } \\
\text { Enfermagem)que abordam } \\
\text { temas de humanização e } \\
\text { algumas disciplinas como } \\
\text { psicologia e antropologia, } \\
\text { facilitam o conhecimento do }\end{array}$ \\
\hline
\end{tabular}


parte das ciências humanas, elas ajudam a conhecer mais não só 0 paciente, mas como a gente também, e entender melhor a vida. É, mas alguns professores, não todos, alguns, assim você percebe que faz 0 que gosta e de certa forma incentiva você, estimula você, puxa vida, mas, não são todos.

Tive problemas com professores no primeiro ano, mas, no final do ano tive experiências boas com outros, mas, eu acho que a faculdade em si, eu acho que tem um pouco de falta de relacionamento entre professor aluno e de outras cursos, professores de outras áreas, acho que deixa um pouco a desejar, mas, eu acho que foi isso.

A primeira vez eu tentei e não consegui, ela disse:_Não se preocupe que amanhã você vai conseguir, você tá suando, não precisa suar, vai dar tudo certo. Com aquela calma, com aquela paciência, pegava na mão, no dia seguinte eu fui, já estava mais calma e consegui, por isso que eu digo a importância do papel do professor, nem tanto como professor, mas como ser humano também.

Eu achei muito legal a postura dela, vai marcar muito, a gente percebe que ela esta ensinando, ela ensina com alegria, com entusiasmo, ela respeita o paciente, ela fala baixo, não grita, trata bem os pacientes, os auxiliares, o astral dela é bom. Situações não promotoras de qualidade de vida.

\begin{tabular}{|l|l|l|}
\hline \multicolumn{1}{|c|}{ CATEGORIAS / FALAS } & PALAVRAS FRASES ÍNDICES & \multicolumn{1}{c|}{$\begin{array}{c}\text { INTERPRETAÇÃO DO } \\
\text { PESQUISADOR }\end{array}$} \\
\hline $\begin{array}{l}\text { Em relação aos estágios, porque } \\
\text { tem professores que não tem muita } \\
\text { ética, não tem paciência, as vezes ele } \\
\text { chama a atenção em frente do } \\
\begin{array}{l}\text { paciente, eu acho que isto é uma } \\
\text { situação muito desagradável, } \\
\text { principalmente se for no inicio do } \\
\text { curso, que a pessoa está crua ainda, } \\
\text { este é um ponto negativo. }\end{array}\end{array}$ & $\begin{array}{l}\text { tem professores que não tem } \\
\text { muita ética, não tem paciência, } \\
\text { as vezes ele chama a atenção } \\
\text { em frente do paciente...este é } \\
\text { um ponto negativo. }\end{array}$ & $\begin{array}{l}\text { Reconhece na postura do } \\
\text { professor um ponto negativo. }\end{array}$ \\
\hline
\end{tabular}

antropologia, que fazem parte 1 paciente e de sí, permitindo das ciências humanas, elas entender melhor a vida. ajudam a conhecer mais não Destaca também a só o paciente, mas como a melhor a vida.

alguns professores ...você percebe que faz o que gosta $e$ de certa forma incentiva você, estimula você

eu acho que tem um pouco de

falta de relacionamento entre professor aluno e de outras áreas, acho que deixa um pouco a desejar.

Não se preocupe que amanhã você vai conseguir, você tá suando, não precisa suar, vai dar tudo certo. Com aquela calma, com aquela paciência, pegava na mão, no dia seguinte eu fui, já estava mais calma e consegui.

...ela ensina com alegria, com entusiasmo, ela respeita o paciente, ela fala baixo, não grita, trata bem os pacientes, os auxiliares, o astral dela é bom. continência do professor gente também, e entender cursos, professores de outras aprendizado.
Reafirma a postura esperada do professor como facilitador, a calma, a alegria, o entusiasmo, respeito ao paciente, falar baixo, não gritar, tratar bem os pacientes e auxiliares.
Afirma a postura de como facilitadora para o

" postura do

Afirma a falta de

professor e aluno e de outros cursos, professores de outras áreas.

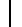
professor " que gosta do que 


\begin{tabular}{|l|l|l|}
\hline \multicolumn{1}{|c|}{ CATEGORIAS / FALAS } & PALAVRAS FRASES ÍNDICES & \multicolumn{1}{|c|}{$\begin{array}{c}\text { INTERPRETAÇÃO DO } \\
\text { PESQUISADOR }\end{array}$} \\
\hline $\begin{array}{l}\text {...falta um pouco de relacionamento, } \\
\text { amizade mesmo, entre as faculdades, } \\
\text { por exemplo: enfermagem, medicina, } \\
\text { biologia, eu acho que tem muito } \\
\text { preconceito em relação a isso, eu } \\
\text { sofri um pouco porque a minha } \\
\text { faixa etária é um pouco diferente da } \\
\text { maioria da minha classe, sofri um } \\
\text { pouco por causa disto. }\end{array}$ & $\begin{array}{l}\text {..falta um pouco de } \\
\text { relacionamento, amizade } \\
\text { mesmo, entre as faculdades, } \\
\text { por exemplo: enfermagem, } \\
\text { medicina, biologia, eu acho } \\
\text { que tem muito preconceito em } \\
\text { relação a isso. }\end{array}$ & $\begin{array}{l}\text { Refere a falta de } \\
\text { entrosamento entre os cursos } \\
\text { relacionando com } \\
\text { preconceito. }\end{array}$ \\
\hline $\begin{array}{l}\text { Ela não se preocupa com a equipe, ela } \\
\text { nem sabe o nome dos pacientes, ela } \\
\text { não faz assistência direta, nem } \\
\text { prescrição de enfermagem, nem nada. } \\
\begin{array}{l}\text { Eu percebo que ela não é } \\
\text { respeitada, mas, também eu } \\
\text { percebo que ela também não gosta } \\
\text { do que ela faz }\end{array}\end{array}$ & $\begin{array}{l}\text { Ela não se preocupa com a } \\
\text { equipe, ela nem sabe o nome } \\
\text { dos pacientes, ela não faz } \\
\text { assistência direta, nem } \\
\text { prescrição de enfermagem, } \\
\text { nem nada. }\end{array}$ & $\begin{array}{l}\text { Enfatiza o modelo de } \\
\text { Enfermeiro que não assume } \\
\text { o seu papel, o que implica em } \\
\text { não ser respeitada. Sugere } \\
\text { que este modelo percebido } \\
\text { se dá por não haver gosto } \\
\text { pela profissão. }\end{array}$ \\
\hline
\end{tabular}

Entrevista 3

Significados de qualidade de vida.

\begin{tabular}{|l|l|l|}
\hline \multicolumn{1}{|c|}{ CATEGORIAS / FALAS } & PALAVRAS FRASES ÍNDICES & \multicolumn{1}{|c|}{$\begin{array}{c}\text { INTERPRETAÇÃO DO } \\
\text { PESQUISADOR }\end{array}$} \\
\hline $\begin{array}{l}\text {...um lugar que funcione uma } \\
\text { estrutura adequada, para que você } \\
\text { possa exercer suas funções } \\
\text { adequadamente. Não só o local, } \\
\text { mas, toda a parte que ela possa ter } \\
\text { estrutura física e também a parte } \\
\text { burocrática tem que oferecer isto. }\end{array}$ & $\begin{array}{l}\text {..o local, mas, toda a parte que } \\
\text { também a parte burocrática } \\
\text { tem que oferecer isto. }\end{array}$ & $\begin{array}{l}\text { Relaciona a qualidade de vida } \\
\text { com as condições da } \\
\text { estrutura física e a } \\
\text { organização do serviço. }\end{array}$ \\
\hline $\begin{array}{l}\text { Também a equipe que trabalha, para } \\
\text { ter qualidade de vida a equipe tem eu } \\
\text { estar bem entrosada, uma equipe que } \\
\text { se entenda, que se conheça, de } \\
\text { preferência que não haja brigas de } \\
\text { quem manda mais, quem faz o que, } \\
\text { haja uma harmonia, uma sincronia. } \\
\begin{array}{l}\text { Não há como ter qualidade de vida } \\
\text { se as pessoas se odeiam ou não se } \\
\text { gostam. }\end{array}\end{array}$ & $\begin{array}{l}\text { equipe tem eu estar bem } \\
\text { entrosada, uma equipe que se } \\
\text { entenda, que se conheça, de } \\
\text { preferência que não haja } \\
\text { brigas de quem manda mais, } \\
\text { quem faz o que, haja uma } \\
\text { harmonia, uma sincronia. }\end{array}$ & $\begin{array}{l}\text { Afirma que o trabalho em } \\
\text { equipe em hamonia, e } \\
\text { sincronia permite uma relação } \\
\text { interpessoal com atitudes de } \\
\text { respeito, diálogo, colaboração } \\
\text { e integração, refletindo na } \\
\text { qualidade de vida. }\end{array}$ \\
\hline $\begin{array}{l}\text { Ah! que também tenha espaço para } \\
\text { o profissional possa se manter } \\
\text { atualizado, possa freqüentar } \\
\text { cursos, congressos, essas coisas. } \\
\text { Isto reflete na qualidade de vida, } \\
\text { porque o profissional que não se } \\
\text { atualiza não pode prestar uma } \\
\text { assistência adequada. }\end{array}$ & $\begin{array}{l}\text { Isto reflete na qualidade de } \\
\text { vida, porque o profissional que } \\
\text { não se atualiza não pode } \\
\text { prestar uma assistência } \\
\text { adequada. }\end{array}$ & $\begin{array}{l}\text { Refere a oportunidade de } \\
\text { atualização dos } \\
\text { conhecimentos como forma } \\
\text { de permitir uma assistência } \\
\text { adequada. Permanece com o } \\
\text { foco de qualidade de vida no } \\
\text { paciente e não em sí. }\end{array}$ \\
\hline
\end{tabular}

Situações promotoras de qualidade de vida.

\begin{tabular}{|c|c|c|}
\hline CATEGORIAS / FALAS & PALAVRAS FRASES ÍNDICES & $\begin{array}{c}\text { INTERPRETAÇÃO DO } \\
\text { PESQUISADOR }\end{array}$ \\
\hline $\begin{array}{l}\text { Eu acho que qualidade de vida tem } \\
\text { muito haver com cidadania, porque } \\
\text { você exercendo sua cidadania você } \\
\text { vai ter uma qualidade de vida } \\
\text { melhor. Lutar por aquilo que a gente } \\
\text { acredita, buscar nossos direitos, } \\
\text { exercer nossos deveres, respeitar, } \\
\text { saber o seu espaço. Eu acho que } \\
\text { cidadania é ligado com qualidade de } \\
\text { vida. }\end{array}$ & $\begin{array}{l}\text { Lutar por aquilo que a gente } \\
\text { acredita, buscar nossos } \\
\text { direitos, exercer nossos } \\
\text { deveres, respeitar, saber o seu } \\
\text { espaço. Eu acho que cidadania } \\
\text { é ligado com qualidade de } \\
\text { vida. }\end{array}$ & $\begin{array}{l}\text { Reconhece na cidadania a } \\
\text { promoção da qualidade de } \\
\text { vida. Lutar por aquilo que } \\
\text { acredita, buscar seus direitos } \\
\text { e deveres, saber o seu } \\
\text { espaço. }\end{array}$ \\
\hline
\end{tabular}




\begin{tabular}{|c|c|c|}
\hline $\begin{array}{l}\text {...qualidade de vida é uma } \\
\text { conversa, um diálogo, uma pessoa } \\
\text { que tem paciência com o } \\
\text { funcionário, é uma distração, uma } \\
\text { música... }\end{array}$ & \begin{tabular}{|l|}
...qualidade de vida é uma \\
conversa, um diálogo, uma \\
pessoa que tem paciência com \\
o funcionário, é uma distração, \\
uma música...
\end{tabular} & $\begin{array}{l}\text { Refere atitudes de diálogo de } \\
\text { acolhimento para com o } \\
\text { funcionário e atividades de } \\
\text { lazer promotoras de } \\
\text { qualidade de vida. }\end{array}$ \\
\hline \multicolumn{3}{|c|}{ Situações não promotoras de qualidade de vida. } \\
\hline CATEGORIAS / FALAS & PALAVRAS FRASES ÍNDICES & $\begin{array}{c}\text { INTERPRETAÇÃO DO } \\
\text { PESQUISADOR }\end{array}$ \\
\hline $\begin{array}{l}\text { Daí a enfermeira passou na porta, e } \\
\text { a gente falou que o menino estava } \\
\text { passando mal, está com muitos } \\
\text { roncos, ele está cianótico. Ele } \\
\text { parecia que ia entrar em convulsão } \\
\text { até. A enfermeira olhou... a enfermeira } \\
\text { olhou.... com cara apática. "Já } \\
\text { venho" Saiu e não voltou! Não voltou } \\
\text { R. }\end{array}$ & $\begin{array}{l}\text { A enfermeira olhou... a } \\
\text { enfermeira olhou.... com cara } \\
\text { apática. - “Já venho." Saiu e } \\
\text { não voltou! Não voltou R. }\end{array}$ & $\begin{array}{l}\text { Descreve o sentimento de } \\
\text { abandono por parte da } \\
\text { enfermeira diante de uma } \\
\text { situação de intervenção. }\end{array}$ \\
\hline $\begin{array}{l}\text { A mãe da criança também foi uma } \\
\text { coisa que eu assustei, ela não estava } \\
\text { no quarto, era daquelas que ficava } \\
\text { investigando a vida alheia A hora } \\
\text { que ela chegou, já iam levar a criança } \\
\text { lá, e ela disse: "Ah! ele fica assim } \\
\text { direto mesmo." Eu senti um descaso } \\
\text { tão grande com a criança. Foi uma } \\
\text { situação que me marcou. }\end{array}$ & $\begin{array}{l}\text { A mãe da criança também foi } \\
\text { uma coisa que eu assustei, ela } \\
\text { não estava no quarto... } \\
\\
\text { A hora que ela chegou, já iam } \\
\text { levar a criança lá, e ela disse: } \\
\text { "Ah! ele fica assim direto } \\
\text { mesmo." Eu senti um descaso } \\
\text { tão grande com a criança. Foi } \\
\text { uma situação que me marcou. }\end{array}$ & $\begin{array}{l}\text { Relaciona a situação de } \\
\text { descaso por parte de outros } \\
\text { cuidadores ( mãe), como uma } \\
\text { situação marcante em seu } \\
\text { aprendizado. }\end{array}$ \\
\hline $\begin{array}{l}\text { Sabe, fiquei mais pasma da nossa } \\
\text { supervisora não tomar providência } \\
\text { também. Fiquei pensando, cadê a } \\
\text { autonomia, elas falam tanto, mas, } \\
\text { porque que a gente não tem isto na } \\
\text { prática? }\end{array}$ & $\begin{array}{l}\text { Sabe, fiquei mais pasma da } \\
\text { nossa supervisora não tomar } \\
\text { providência também. Fiquei } \\
\text { pensando, cadê a autonomia, } \\
\text { elas falam tanto, mas, porque } \\
\text { que a gente não tem isto na } \\
\text { prática? }\end{array}$ & $\begin{array}{l}\text { Refere que a falta de atuação } \\
\text { da supervisora, a fez perceber } \\
\text { a dicotomia da teoria e da } \\
\text { prática. }\end{array}$ \\
\hline $\begin{array}{l}\text { E lá nossa eu não sei, eu via a vida } \\
\text { se esvair, e se fosse minha mãe, se } \\
\text { fosse... acha que eu ia ficar } \\
\text { parada?? Mas nunca!! Porque eu } \\
\text { me senti culpada de não ter feito } \\
\text { alguma coisa, sabe, não sei. }\end{array}$ & $\begin{array}{l}\text {...eu via a vida se esvair, e se } \\
\text { fosse minha mãe, se fosse... } \\
\text { acha que eu ia ficar parada?? } \\
\text { Mas nunca!! Porque eu me } \\
\text { senti culpada de não ter feito } \\
\text { alguma coisa, sabe, não sei. }\end{array}$ & $\begin{array}{l}\text { Descreve uma situação de } \\
\text { morte, de transferência para } \\
\text { alguém que poderia ser sua } \\
\text { mãe. Relata o conflito pela } \\
\text { impotência diante da morte e } \\
\text { culpa por não ter tomada uma } \\
\text { atitude. }\end{array}$ \\
\hline $\begin{array}{l}\text { E ali na emergência, ainda mais } \\
\text { aluno, fica desesperado. E naquele } \\
\text { momento veio tudo, eu sabia o que } \\
\text { eu tinha que fazer. Isto é o que me } \\
\text { deixou mais triste. Porque quando a } \\
\text { gente erra por falta de experiência, } \\
\text { tudo bem entre aspas, mas, eu sabia } \\
\text { o que eu tinha que fazer, eu só não } \\
\text { fiz porque não me deixaram, não } \\
\text { me deram a ordem. }\end{array}$ & $\begin{array}{l}\text { E ali na emergência, ainda } \\
\text { mais aluno, fica desesperado. } \\
\text { E naquele momento veio tudo, } \\
\text { eu sabia o que eu tinha que } \\
\text { fazer. Isto é o que me deixou } \\
\text { mais triste. } \\
\text { mas, eu sabia o que eu tinha } \\
\text { que fazer, eu só não fiz porque } \\
\text { não me deixaram, não me } \\
\text { deram a ordem. }\end{array}$ & $\begin{array}{l}\text { Relata a situação de estágio } \\
\text { na emergência com o uma } \\
\text { situação geradora de } \\
\text { desespero. } \\
\text { Ressalta que apesar de saber } \\
\text { o que fazer e poder fazer na } \\
\text { situação. Mais uma vez } \\
\text { chama a atenção para a falta } \\
\text { de autonomia. A falta de } \\
\text { acolhimento do conflito } \\
\text { existente, parece ter deixado } \\
\text { tristeza. }\end{array}$ \\
\hline $\begin{array}{l}\text { Gerou sentimentos de revolta, } \\
\text { sentimentos de muitos porquês, e } \\
\text { sem resposta, isto que é mais } \\
\text { triste! }\end{array}$ & $\begin{array}{l}\text { Gerou sentimentos de revolta, } \\
\text { sentimentos de muitos } \\
\text { porquês, e sem resposta, isto } \\
\text { que é mais triste! }\end{array}$ & $\begin{array}{l}\text { Reafirma como a falta de } \\
\text { acolhimento e de estratégia } \\
\text { de enfrentamento geram } \\
\text { sentimentos e sofrimento } \\
\text { psíquico }\end{array}$ \\
\hline
\end{tabular}


Entrevista 4

Significados de qualidade de vida

\begin{tabular}{|l|l|l|}
\hline \multicolumn{1}{|c|}{ CATEGORIAS / FALAS } & PALAVRAS FRASES ÍNDICES & \multicolumn{1}{|c|}{$\begin{array}{c}\text { INTERPRETAÇÃO DO } \\
\text { PESQUISADOR }\end{array}$} \\
\hline $\begin{array}{l}\text { Qualidade de vida no trabalho é a } \\
\text { carga horária, acho que a carga } \\
\text { horária do enfermeiro é bem alta. } \\
\text { Tem lugares que são 40, 32 ou } 30 \\
\text { horas, o ideal seria trabalhar } 6 \text { horas } \\
\text { e ter um emprego só para estar } \\
\text { mantendo uma qualidade razoável. }\end{array}$ & $\begin{array}{l}\text { o ideal seria trabalhar } 6 \text { horas } \\
\text { e ter um emprego só para } \\
\text { estar mantendo uma qualidade } \\
\text { razoável. }\end{array}$ & $\begin{array}{l}\text { Revela como ideal trabalhar } \\
\text { em um único emprego. }\end{array}$ \\
\hline $\begin{array}{l}\text { olha no estágio nos acabamos } \\
\text { perdendo um pouco a qualidade } \\
\text { devido as dificuldades } \\
\text { apresentadas no campo. Como falta } \\
\text { de material, falta de medicamentos, e } \\
\text { isto acaba estressando, afetando e a } \\
\text { qualidade já está caindo. }\end{array}$ & $\begin{array}{l}\text { Como falta de material, falta de } \\
\text { medicamentos, e isto acaba } \\
\text { estressando, afetando e a }\end{array}$ & $\begin{array}{l}\text { Relaciona a existência dos } \\
\text { recursos materiais no campo } \\
\text { de estágio com qualidade de } \\
\text { vida, por não gerar estress. }\end{array}$ \\
\hline $\begin{array}{l}\text { Tem que estar bem fisicamente para } \\
\text { a sua qualidade de vida estar boa. } \\
\text { Então eu acho que no trabalho } \\
\text { seria isso. }\end{array}$ & $\begin{array}{l}\text { Tem que estar bem } \\
\text { fisicamente para a sua } \\
\text { qualidade de vida estar boa. }\end{array}$ & $\begin{array}{l}\text { Relacionam a qualidade de } \\
\text { vida com o bem estar físico. }\end{array}$ \\
\hline
\end{tabular}

seria isso.

Situações promotoras de qualidade de vida.

\begin{tabular}{|c|c|c|}
\hline CATEGORIAS / FALAS & PALAVRAS FRASES ÍNDICES & $\begin{array}{c}\text { INTERPRETAÇÃO DO } \\
\text { PESQUISADOR }\end{array}$ \\
\hline $\begin{array}{l}\text { em casa eu tenho a minha vida, } \\
\text { com a minha família, meu filho, } \\
\text { meu lazer, com as minhas coisas, } \\
\text { mas, assim sempre tem aquela } \\
\text { ansiedade, aquela vontade até de } \\
\text { ligar para saber se o paciente } \\
\text { melhorou, saber como ele está }\end{array}$ & $\begin{array}{l}\text { assim sempre tem aquela } \\
\text { ansiedade, aquela vontade até } \\
\text { de ligar para saber se o } \\
\text { paciente melhorou, saber } \\
\text { como ele está }\end{array}$ & $\begin{array}{l}\text { Afirma que preocupa-se com o } \\
\text { paciente mesmo em } \\
\text { momentos com a família. }\end{array}$ \\
\hline $\begin{array}{l}\text {...então qualidade de vida do paciente } \\
\text { eu já vivenciei um monte, mas, assim } \\
\text { em relação ao meu estágio, ao } \\
\text { profissional eu não sei. }\end{array}$ & $\begin{array}{l}\text {...então qualidade de vida do } \\
\text { paciente eu já vivenciei um } \\
\text { monte, mas, assim em relação } \\
\text { ao meu estágio, ao } \\
\text { profissional eu não sei. }\end{array}$ & $\begin{array}{l}\text { Desconhece qualidade de vida } \\
\text { para o profissional e para o } \\
\text { aluno }\end{array}$ \\
\hline $\begin{array}{l}\text { Olha eu andava de moto, depois que } \\
\text { eu fiz estágio no Pronto Socorro, } \\
\text { eu vi muitos acidentes de moto, } \\
\text { então, talvez tenha melhorado a } \\
\text { minha qualidade de vida, porque eu } \\
\text { não vou mais andar de moto. }\end{array}$ & $\begin{array}{l}\text {... depois que eu fiz estágio no } \\
\text { Pronto Socorro, eu vi muitos } \\
\text { acidentes de moto, então, } \\
\text { talvez tenha melhorado a } \\
\text { minha qualidade de vida, } \\
\text { porque eu não vou mais andar } \\
\text { de moto. }\end{array}$ & $\begin{array}{l}\text { Conta que a vivência no } \\
\text { campo de estágio a fez mudar } \\
\text { de postura melhorando sua } \\
\text { qualidade de vida. }\end{array}$ \\
\hline
\end{tabular}

Situações não promotoras de qualidade de vida.

\begin{tabular}{|c|c|c|}
\hline CATEGORIAS / FALAS & PALAVRAS FRASES ÍNDICES & $\begin{array}{l}\text { INTERPRETAÇÃO DO } \\
\text { PESQUISADOR }\end{array}$ \\
\hline $\begin{array}{l}\text { Então para mim o que mais afetou } \\
\text { minha qualidade de vida foi eu } \\
\text { estar trabalhando, você vê a } \\
\text { diferença do aluno que trabalha do } \\
\text { aluno que não trabalha, ele aproveita } \\
\text { mais, ele se doa inteiramente e o } \\
\text { aluno que trabalha já não é a mesma } \\
\text { coisa, chega cansado, muitas vezes a } \\
\text { matéria é interessante, você está a } \\
\text { fim de aprender, mas você, o cansaço } \\
\text { físico é muito grande e isto interfere } \\
\text { na qualidade de vida. }\end{array}$ & $\begin{array}{l}\text {...estar trabalhando, você vê a } \\
\text { diferença do aluno que } \\
\text { trabalha do aluno que não } \\
\text { trabalha, ele aproveita mais, } \\
\text { ele se doa inteiramente e o } \\
\text { aluno que trabalha já não é a } \\
\text { mesma coisa, chega cansado, } \\
\text { muitas vezes a matéria é } \\
\text { interessante, você está a fim } \\
\text { de aprender, mas você, o } \\
\text { cansaço físico é muito grande } \\
\text { e isto interfere na qualidade de } \\
\text { vida. }\end{array}$ & $\begin{array}{l}\text { Revela que a condição de } \\
\text { aluno trabalhador interfere no } \\
\text { aprendizado e na qualidade de } \\
\text { vida. }\end{array}$ \\
\hline Na nossa sala acho que tem mais & ...alunos que trabalham ... tem & Afirma que o aluno trabalhador \\
\hline
\end{tabular}




\begin{tabular}{|l|l|l|}
\hline $\begin{array}{l}\text { uns } 10 \text { alunos que trabalham, por isto } \\
\text { que eu vejo tem aluno que se doa } \\
\text { tanto que chega a adoecer. }\end{array}$ & $\begin{array}{l}\text { aluno que se doa tanto que } \\
\text { chega a adoecer. }\end{array}$ & adoece. \\
\hline $\begin{array}{l}\text { Ah! mas é gostoso você vê alguém } \\
\text { que está ali encolhida, deprimida e } \\
\text { você consegue animar esta pessoa!! }\end{array}$ & $\begin{array}{l}\text {..Tá na alma, você deita dormir, } \\
\text { você está até mais leve, já inclui } \\
\text { o paciente nas suas orações... } \\
\text { dormir, você está até mais leve, já } \\
\text { inclui o paciente nas suas orações... }\end{array}$ & $\begin{array}{l}\text { Afirma o prazer que sente em } \\
\text { relação ao cuidar do outro e } \\
\text { que este é lembrado mesmo } \\
\text { fora do contexto hospitalar. }\end{array}$ \\
\hline $\begin{array}{l}\text { enfermeira vindo de um plantão } \\
\text { pro outro, vindo cansada, as vezes } \\
\text { sendo grossa, com funcionários, } \\
\text { eu acho que está carga horária de } \\
\text { dois empregos, virá } 24 \text { horas de } \\
\text { plantão, estressa muito porque por } \\
\text { mais que a gente goste de ficar } \\
\text { dentro do hospital, você precisa da } \\
\text { sua casa, dormir. }\end{array}$ & $\begin{array}{l}\text { empregos, virá } 24 \text { horas de } \\
\text { plantão, estressa muito... }\end{array}$ & $\begin{array}{l}\text { Refere-se a carga horária } \\
\text { como causa de estress. }\end{array}$ \\
\hline
\end{tabular}

Entrevista 5

Significados de qualidade de vida.

\begin{tabular}{|l|l|l|}
\hline \multicolumn{1}{|c|}{ CATEGORIAS / FALAS } & PALAVRAS FRASES ÍNDICES & \multicolumn{1}{c|}{$\begin{array}{c}\text { INTERPRETAÇÃO DO } \\
\text { PESQUISADOR }\end{array}$} \\
\hline $\begin{array}{l}\text { Então, acho que se tiver um } \\
\text { ambiente agradável com todos os } \\
\text { recursos, com um suporte adequado, } \\
\text { para na hora que precisar ter o } \\
\text { material na mão, funcionando, tudo } \\
\text { certinho, acho que isto já ajuda } \\
\text { bastante na qualidade de vida, } \\
\begin{array}{l}\text { porque, já diminui o desgaste } \\
\text { profissional. }\end{array}\end{array}$ & $\begin{array}{l}\text { agradável com todos os } \\
\text { recursos, com um suporte } \\
\text { adequado, para na hora que } \\
\text { precisar ter o material na } \\
\text { mão... isto já ajuda bastante } \\
\text { na qualidade de vida, porque, } \\
\text { já diminui o desgaste } \\
\text { profissional. }\end{array}$ & $\begin{array}{l}\text { Afirma que a estrutura e a } \\
\text { organização do local de } \\
\text { trabalho favorece a qualidade } \\
\text { de vida. }\end{array}$ \\
\hline $\begin{array}{l}\text { Também a parte de relacionamento } \\
\text { profissional, influencia bastante na } \\
\text { qualidade de vida. }\end{array}$ & $\begin{array}{l}\text { Relacionamento profissional, } \\
\text { influencia bastante na } \\
\text { qualidade de vida. }\end{array}$ & $\begin{array}{l}\text { Relaciona o relacionamento } \\
\text { profissional com a qualidade } \\
\text { de vida. }\end{array}$ \\
\hline
\end{tabular}

Situações promotoras de qualidade de vida.

\begin{tabular}{|c|c|c|}
\hline CATEGORIAS / FALAS & PALAVRAS FRASES ÍNDICES & $\begin{array}{l}\text { INTERPRETAÇÃO DO } \\
\text { PESQUISADOR }\end{array}$ \\
\hline $\begin{array}{l}\text { Tive experiências muito boas durante } \\
\text { o curso. Foram trabalhos de grupos, } \\
\text { com pacientes ou outras pessoas da } \\
\text { comunidade que, assim, as } \\
\text { pessoas realmente participam, e a } \\
\text { gente pode colaborar de alguma } \\
\text { maneira com elas. }\end{array}$ & $\begin{array}{l}\text {...experiências muito boas } \\
\text { durante o curso. Foram } \\
\text { trabalhos de grupos, com } \\
\text { pacientes ou outras pessoas } \\
\text { da comunidade...as pessoas } \\
\text { realmente participam, e a } \\
\text { gente pode colaborar de } \\
\text { alguma maneira com elas. }\end{array}$ & $\begin{array}{l}\text { Considera como experiência } \\
\text { boa o trabalho de grupo com a } \\
\text { comunidade e o quanto isto } \\
\text { contribui para os mesmos. }\end{array}$ \\
\hline $\begin{array}{l}\text { Pra mim foi muito bom, foi um } \\
\text { assunto que eu também posso } \\
\text { aproveitar pra mim, agora, eu acho } \\
\text { que a partir do momento que você } \\
\text { tem um bom resultado, acrescenta } \\
\text { alguma coisa, só pelo fato de você } \\
\text { não ficar com aquela frustração, } \\
\text { imagina você prepara tudo e não } \\
\text { aparece ninguém. }\end{array}$ & $\begin{array}{l}\text {...a partir do momento que } \\
\text { você tem um bom resultado, } \\
\text { acrescenta alguma coisa, só } \\
\text { pelo fato de você não ficar } \\
\text { com aquela frustração, } \\
\text { imagina você prepara tudo e } \\
\text { não aparece ninguém. }\end{array}$ & $\begin{array}{l}\text { Relata que o resultado positivo } \\
\text { do trabalho desenvolvido } \\
\text { acrescenta alguma coisa. }\end{array}$ \\
\hline $\begin{array}{l}\text { Na disciplina de estágio } \\
\text { supervisionado de estar trabalhando } \\
\text { um pouco mais solto, um pouco mais } \\
\text { independente, trazendo a } \\
\text { responsabilidade pra gente, } \\
\text { aprendendo a caminhar sozinho, foi } \\
\text { muito bom. Eu cresci bastante. }\end{array}$ & $\begin{array}{l}\text { Na disciplina de estágio } \\
\text { supervisionado de estar } \\
\text { trabalhando um pouco mais } \\
\text { solto, um pouco mais } \\
\text { independente, trazendo a } \\
\text { responsabilidade pra gente, } \\
\text { aprendendo a caminhar } \\
\text { sozinho, foi muito bom. Eu } \\
\text { cresci bastante. }\end{array}$ & $\begin{array}{l}\text { Refere que a dinâmica do } \\
\text { estágio supervisionado } \\
\text { influenciou no seu crescimento. }\end{array}$ \\
\hline
\end{tabular}




\begin{tabular}{|c|c|c|}
\hline $\begin{array}{l}\text { Uma coisa que promove a } \\
\text { qualidade de vida, principalmente } \\
\text { para o aluno é ser bem recebido no } \\
\text { setor. Poder contar com os } \\
\text { enfermeiros, que eles dêem atenção, } \\
\text { porque as vezes a gente quer } \\
\text { perguntar alguma coisa e não } \\
\text { consegue nem ser ouvido. }\end{array}$ & $\begin{array}{l}\text {... é ser bem recebido no setor. } \\
\text { Poder contar com os } \\
\text { enfermeiros, que eles dêem } \\
\text { atenção, porque as vezes a } \\
\text { gente quer perguntar alguma } \\
\text { coisa e não consegue nem ser } \\
\text { ouvido. }\end{array}$ & $\begin{array}{l}\text { Afirma a importância do } \\
\text { acolhimento pelos enfermeiros } \\
\text { de campo como promotor de } \\
\text { qualidade de vida. }\end{array}$ \\
\hline
\end{tabular}

consegue nem ser ouvido.

Situações não promotoras de qualidade de vida.

\begin{tabular}{|c|c|c|}
\hline CATEGORIAS / FALAS & PALAVRAS FRASES ÍNDICES & $\begin{array}{c}\text { INTERPRETAÇÃO DO } \\
\text { PESQUISADOR }\end{array}$ \\
\hline $\begin{array}{l}\text { Eu, no meu estágio de PS saía } \\
\text { triste, todo dia que eu ia lá, todo o } \\
\text { dia, porque, você vê muita coisa } \\
\text { errada. Você vê a situação ali já é } \\
\text { pesada é difícil, e ainda, você tem } \\
\text { um ambiente que não colabora, e é } \\
\text { então acho tem que tomar uma } \\
\text { solução, pausa, rs...Já estou } \\
\text { fugindo do assunto. }\end{array}$ & $\begin{array}{l}\text {... você vê muita coisa errada. } \\
\text { Você vê a situação ali já é } \\
\text { pesada é difícil, e ainda, você } \\
\text { tem um ambiente que não } \\
\text { colabora... }\end{array}$ & $\begin{array}{l}\text { Refere o campo de estágio e } \\
\text { ao perfil dos pacientes como } \\
\text { desfavorável para a qualidade } \\
\text { de vida. }\end{array}$ \\
\hline $\begin{array}{l}\text { Eu acho que se alguém quer } \\
\text { buscar qualidade de vida para os } \\
\text { alunos, os futuros profissionais, } \\
\text { tem que começar por arrumar uma } \\
\text { estratégia para diminuir...é tudo } \\
\text { bem, aluno é aluno, precisa de } \\
\text { cobrança, mas, tem gente que não } \\
\text { sabe dosar, tem gente que cobra } \\
\text { tanto, que acaba causando trauma } \\
\text { para a pessoa. }\end{array}$ & $\begin{array}{l}\text {...aluno é aluno, precisa de } \\
\text { cobrança, mas, tem gente que } \\
\text { não sabe dosar, tem gente que } \\
\text { cobra tanto, que acaba } \\
\text { causando trauma para a } \\
\text { pessoa. }\end{array}$ & $\begin{array}{l}\text { Afirma que a relação professor } \\
\text { aluno no sentido de cobrança } \\
\text { causando trauma no aluno. }\end{array}$ \\
\hline $\begin{array}{l}\text { Eu não tive muito problema com } \\
\text { professor, com relacionamento, } \\
\text { mas, teve gente que teve. Eu já } \\
\text { tinha uma maturidade maior, uma } \\
\text { facilidade maior de estar } \\
\text { aprendendo eu já sabia como } \\
\text { lidar, como era o esquema de uma } \\
\text { faculdade. Agora, eu observei } \\
\text { muitas pessoas que não sei se foi } \\
\text { porque não tinham experiência ou } \\
\text { maturidade é, que sofreram muito, de } \\
\text { precisar fazer sessão com psicólogo } \\
\text { para livrar -se do trauma, de chegar } \\
\text { e tremer, só de ver a pessoa. }\end{array}$ & $\begin{array}{l}\text {... eu observei muitas pessoas } \\
\text { que não sei se foi porque não } \\
\text { tinham experiência ou } \\
\text { maturidade é, que sofreram } \\
\text { muito, de precisar fazer } \\
\text { sessão com psicólogo para } \\
\text { livrar -se do trauma, de } \\
\text { chegar e tremer, só de ver a } \\
\text { pessoa. }\end{array}$ & $\begin{array}{l}\text { Refere ao trauma gerado na } \\
\text { relação professor -aluno }\end{array}$ \\
\hline $\begin{array}{l}\text {...porque eu estava trabalhando, até } \\
\text { que, eu podia ter rendido, produzido } \\
\text { coisas melhores, eu gostaria de ter } \\
\text { participado em um trabalho } \\
\text { cientifico na faculdade, mas o meu } \\
\text { tempo para pesquisar fora foi } \\
\text { muito escasso. }\end{array}$ & $\begin{array}{l}\text {...porque eu estava } \\
\text { trabalhando, até que, eu podia } \\
\text { ter rendido, produzido coisas } \\
\text { melhores... }\end{array}$ & $\begin{array}{l}\text { Refere que pelo fato de } \\
\text { trabalhar teve tempo escasso } \\
\text { para desenvolver coisas } \\
\text { melhores. } \\
\text { Afirma a falta de possibilidades } \\
\text { para o aluno trabalhador } \\
\text { desenvolver outras atividades } \\
\text { acadêmicas. }\end{array}$ \\
\hline $\begin{array}{l}\text { A gente respeita muito a profissão de } \\
\text { professor, porque, tem toda uma } \\
\text { bagagem de conhecimento e se } \\
\text { não fossem eles a gente não seria } \\
\text { nada também, mas, eu acho que } \\
\text { tivesse um pouco mais de educação } \\
\text { ia melhorar muito a qualidade de } \\
\text { vida. }\end{array}$ & $\begin{array}{l}\text { A gente respeita muito a } \\
\text { profissão de professor...mas, eu } \\
\text { acho que tivesse um pouco mais } \\
\text { de educação ia melhorar muito a } \\
\text { qualidade de vida. }\end{array}$ & $\begin{array}{l}\text { Apesar de valorizarem o papel } \\
\text { do professor, chamam a } \\
\text { atenção para a postura do } \\
\text { professor na relação com o } \\
\text { aluno no sentido de ser } \\
\text { educado. }\end{array}$ \\
\hline
\end{tabular}




\begin{tabular}{|c|c|c|}
\hline $\begin{array}{l}\text { talvez traga melhoria na qualidade de } \\
\text { vida, é a integração. Não sei porque } \\
\text { os alunos da enfermagem, não } \\
\text { conseguem se integrar, é muito } \\
\text { separado, pra nada, nada, você } \\
\text { tem apoio, nada eles aceitam, sei } \\
\text { lá talvez traga melhoria na qualidade } \\
\text { de vida, é a integração. }\end{array}$ & $\begin{array}{l}\text { talvez traga melhoria na } \\
\text { qualidade de vida, é a } \\
\text { integração... talvez traga } \\
\text { melhoria na qualidade de vida, } \\
\text { é a integração. }\end{array}$ & $\begin{array}{l}\text { Sugere a integração dos alunos } \\
\text { como promotor de qualidade de } \\
\text { vida. }\end{array}$ \\
\hline $\begin{array}{l}\text { Eu acho que devia ter alguma coisa } \\
\text { visando o lazer, eu principalmente } \\
\text { durante o curso teve carência de } \\
\text { lazer, mas alguma coisa que vise } \\
\text { lazer, sei lá, eu gosto muito de } \\
\text { artesanato, talvez fosse alguma } \\
\text { forma de estar ajudando, uma } \\
\text { outra maneira que não seja } \\
\text { competitivo. }\end{array}$ & $\begin{array}{l}\text {...devia ter alguma coisa } \\
\text { visando o lazer, eu } \\
\text { principalmente durante o } \\
\text { curso teve carência de lazer... }\end{array}$ & $\begin{array}{l}\text { Aponta o laser como algo que } \\
\text { faltou durante a sua formação e } \\
\text { sugere que o mesmo seja } \\
\text { incluído como algo que } \\
\text { promova a qualidade de vida. }\end{array}$ \\
\hline $\begin{array}{l}\text { uma coisa que é muito difícil é a } \\
\text { questão da carga horária da } \\
\text { faculdade. É muito limitada, não } \\
\text { sei se é esta a palavra, por } \\
\text { exemplo: quando você precisa de } \\
\text { alguma coisa, tem um evento extra, } \\
\text { uma coisa que os alunos querem } \\
\text { fazer, nenhum professor quer } \\
\text { dispensar os alunos, por melhor } \\
\text { que seja a proposta, ou mesmo } \\
\text { quando a pessoa se interessa, } \\
\text { coisas que também poderia estar } \\
\text { contribuindo para o crescimento } \\
\text { dos alunos, acaba sendo proibido, } \\
\text { oportunidades acabam sendo } \\
\text { deixadas de lado. }\end{array}$ & $\begin{array}{l}\text {... quando você precisa de } \\
\text { alguma coisa, tem um evento } \\
\text { extra, uma coisa que os } \\
\text { alunos querem fazer, nenhum } \\
\text { professor quer dispensar os } \\
\text { alunos... }\end{array}$ & $\begin{array}{l}\text { Afirma a necessidade dos } \\
\text { alunos poderem participar de } \\
\text { eventos com a autorização dos } \\
\text { professores. }\end{array}$ \\
\hline $\begin{array}{l}\text { a Semana de Enfermagem é um } \\
\text { negócio, era uma semana, } \\
\text { resumiram em dois dias, tem } \\
\text { muitas coisas boas, em pouco } \\
\text { tempo, tantas horas ali, eu acho } \\
\text { interessante, parte das pessoas } \\
\text { não participam, e outra coisa, este } \\
\text { ano a gente ficou muito sentido, } \\
\text { porque a passagem da bandeira, é } \\
\text { uma exemplo, é uma tradição, é um } \\
\text { símbolo que pode estar ajudando no } \\
\text { relacionamento dos alunos e que foi } \\
\text { deixado praticamente para segundo } \\
\text { plano }\end{array}$ & $\begin{array}{l}\text { a Semana de Enfermagem... a } \\
\text { gente ficou muito sentido, } \\
\text { porque a passagem da } \\
\text { bandeira, é uma exemplo, é } \\
\text { uma tradição, é um símbolo } \\
\text { que pode estar ajudando no } \\
\text { relacionamento dos alunos e } \\
\text { que foi deixado praticamente } \\
\text { para segundo plano. }\end{array}$ & $\begin{array}{l}\text { Desabafa a tristeza por não } \\
\text { terem vivenciado o ritual da } \\
\text { passagem da bandeira. } \\
\text { Ressalta a Semana da } \\
\text { Enfermagem como } \\
\text { oportunidade de integração. }\end{array}$ \\
\hline $\begin{array}{l}\text { Começa as 8:00 porque o setor } \\
\text { que você está em estágio fora } \\
\text { geralmente começa a funcionar as } \\
\text { 8:00, um tempo que você podia } \\
\text { aproveitar, você acaba ficando } \\
\text { menos tempo no local. Muitos alunos } \\
\text { dão graças. A pessoa tem que saber } \\
\text { dosar, não prejudicar o aluno se } \\
\text { precisar, tanto para participar de } \\
\text { algum evento ou quando precisa sair. }\end{array}$ & $\begin{array}{l}\text { em estágio fora geralmente } \\
\text { começa a funcionar as 8:00, um } \\
\text { tempo que você podia } \\
\text { aproveitar, você acaba ficando } \\
\text { menos tempo no local. Muitos } \\
\text { alunos dão graças. A pessoa } \\
\text { tem que saber dosar, não } \\
\text { prejudicar o aluno se precisar, } \\
\text { tanto para participar de algum } \\
\text { evento ou quando precisa sair. }\end{array}$ & $\begin{array}{l}\text { Declara que o tempo de aula } \\
\text { deveria ser mais aproveitado } \\
\text { ou mesmo negociado quando } \\
\text { houvesse necessidade. }\end{array}$ \\
\hline
\end{tabular}

